\title{
Integrative overview of antibodies against SARS-CoV-2 and their possible applications in COVID-19 prophylaxis and treatment
}

\author{
Norma A. Valdez-Cruz ${ }^{*}$, Enrique García-Hernández², Clara Espitia ${ }^{3}$, Laura Cobos-Marín ${ }^{4}$, \\ Claudia Altamirano ${ }^{5}$, Carlos G. Bando-Campos ${ }^{1}$, Luis F. Cofas-Vargas² ${ }^{2}$ Enrique W. Coronado-Aceves ${ }^{3}$, \\ Ricardo A. González-Hernández ${ }^{1}$, Pablo Hernández-Peralta ${ }^{4}$, Daniel Juárez-López ${ }^{1}$, Paola A. Ortega-Portilla ${ }^{3}$, \\ Sara Restrepo-Pineda ${ }^{1}$, Patricio Zelada-Cordero ${ }^{1}$ and Mauricio A. Trujillo-Roldán ${ }^{1 *}$ (1)
}

\begin{abstract}
SARS-CoV-2 is a novel $\beta$-coronavirus that caused the COVID-19 pandemic disease, which spread rapidly, infecting more than 134 million people, and killing almost 2.9 million thus far. Based on the urgent need for therapeutic and prophylactic strategies, the identification and characterization of antibodies has been accelerated, since they have been fundamental in treating other viral diseases. Here, we summarized in an integrative manner the present understanding of the immune response and physiopathology caused by SARS-CoV-2, including the activation of the humoral immune response in SARS-CoV-2 infection and therefore, the synthesis of antibodies. Furthermore, we also discussed about the antibodies that can be generated in COVID-19 convalescent sera and their associated clinical studies, including a detailed characterization of a variety of human antibodies and identification of antibodies from other sources, which have powerful neutralizing capacities. Accordingly, the development of effective treatments to mitigate COVID-19 is expected. Finally, we reviewed the challenges faced in producing potential therapeutic antibodies and nanobodies by cell factories at an industrial level while ensuring their quality, efficacy, and safety.
\end{abstract}

\section{Introduction}

The recent disease outbreak caused by the new severe acute respiratory syndrome coronavirus 2 (SARS-CoV-2) is a global health emergency, as april 2021 affecting more

\footnotetext{
*Correspondence: adri@biomedicas.unam.mx; maurotru@biomedicas.unam. $\mathrm{mx}$

1 Programa de Investigación de Producción de Biomoléculas, Departamento de Biología Molecular y Biotecnología, Instituto de Investigaciones Biomédicas, Universidad Nacional Autónoma de México, Ciudad Universitaria, 04510 Ciudad de México, México

Full list of author information is available at the end of the article This article is dedicated to the memory of Dr. José de Jesús García Valdés of the Facultad de Química, Universidad Nacional Autónoma de México, a pioneer in the study of ion-channels and scorpion toxins in México.
}

than 134 million people and leading to almost 2.9 million deaths until date [1]. In the last two decades, other SARS-CoV-2-related pathogenic $\beta$-coronaviruses have caused syndromes such as severe acute respiratory syndrome (SARS-CoV) and Middle East respiratory syndrome (MERS-CoV). SARS-CoV-2 is the causative agent of coronavirus disease (COVID-19). As the most transmissible coronavirus $(\mathrm{CoV})$ identified to date, its vertiginous spread has led to the current COVID-19 pandemic [2-5]. This emphasizes the urgency in the research, design, innovation, and large-scale production of new prophylactic and therapeutic drugs.

$\mathrm{CoVs}$ are enveloped single-stranded positive-sense RNA viruses that can infect an extensive number of 
hosts. Human CoVs (order Nidovirales, family Coronaviridae, subfamily Coronavirinae) are zoonotic pathogens, i.e., they can infect humans via interspecies transmission [6-8]. SARS-CoV-2 is a $\beta$-coronavirus that has four structural proteins: the nucleocapsid $(\mathrm{N})$, membrane (M), envelope (E), and surface-anchored spike glycoprotein $(\mathrm{S})$, which is proteolytically processed, generating a trimmer with three $S_{1}$ subunit heads sitting on top of a trimeric $S_{2}$ subunit, that allow the subsequent virus fusion [9-11]. The $S$ protein, through its three receptor binding domains (RBDs), interacts with the human angiotensin-converting enzyme (hACE2), as an entry receptor, and the $S_{2}$ subunit induces fusion to the cell membrane [10, 12-15]. For this reason, the $\mathrm{S}$ protein represents an interesting target for the rational production of vaccines or therapeutic antibodies (Abs) preventing infection [16-18]. Due to the extensive transmission worldwide, the genetic diversity of the virus is dynamic. Recurrent mutations may indicate a convergent evolution for adaptation in humans, similar to those occurring in the $\mathrm{S}$ protein [19].

Since the beginning of the SARS-CoV-2 infectious outbreak, diverse antiviral chemical compounds have been tested in the clinic, showing different efficacies. For instance, the antiviral remdesivir is authorized in the United States for emergency use in humans [20, 21], although some trials do not show substantive benefits [22]. Moreover, approximately 180 vaccine candidates are under development awaiting expedited approval, upon demonstration of proof of quality, safety, and efficacy. More than four different vaccines are approved for emergency use by the Food and Drug Administration (FDA) and other regulatory agencies [23-25]. In addition, various recombinant monoclonal antibodies (mAbs) are being tested in therapy, with targets such as C5a, IL-6, and PD-1, among others, to curb some of the responses caused by SARS-CoV-2 [23]. Similarly, various mAbs developed and tested against other CoVs, including SARS-CoV and MERS-CoV, have been tested against SARS-CoV-2 to treat COVID-19 [3, 12, 26-30]. Alternatively, the World Health Organization recommends the use of plasma from convalescent patients as a therapy to treat critically ill patients globally [5, 31, 32]. Therefore, there is a need for the development of effective and safe COVID-19-specific vaccines or therapeutic drugs. Neutralizing Abs are one of the best candidates for neutralizing virus infection due to their antigenic specificity [12, $29,30,32]$. Artificial passive immunization was born as a therapy based on antibodies transference from serum of immunized animals or humans to a recipient, conferring an immune state against the target [33]. Furthermore, this is one of the most employed immunotherapies in medicine history, supported by a long list of uses based on its neutralization activities upon infectious diseases as produced by bacterial toxins as Corynebacterium diphteriae [34], Clostridium tetani [35], Staphylococcus aureus [36], Clostridium dificile [37], Bordetella pertussis [38], among others. Also, successful viral neutralization had been described such as Enterovirus [39], Hepatitis B virus [40], Measles virus [41], Parvovirus [42], Rabies virus [43], Respiratory syncytial virus (RSV) [44] and Varicella-zoster virus [45]. Nowadays, there is technology to produce monoclonal high-specific and long-lasting antibodies from in vitro systems [46], which means a relevant therapeutic weapon to fight a wide spectrum of infections and other pathologies. Whilst active immunization by infection or vaccination requires a period of time to generate its own system antibodies, passive immunity represents an instantly effective source which induces immunological events as neutralization, opsonization, complement activation and antibody dependent cellular cytotoxicity (ADCC). Furthermore, passive immunity does not depend on recipient immune response which implies a critical instrument to treat immunocompromised patients and other vulnerable groups who cannot be exposed to the antigen itself. In front of COVID-19 pandemic, antibody-based humoral passive immunization treatment is a promising route to treat severe cases, or people who do not respond to vaccination or cannot be vaccinated.

There are several reviews on specific aspects of Abs or its formats as alternative treatments for COVID-19 [47-51]. Moreover, information about Abs is updated daily and is tremendously enriched, then different public databases have compiled information, allowing quick searches $[52,53]$. Here, we update the knowledge regarding the immune response associated with COVID-19, the formation of neutralizing Abs towards SARS-CoV-2 in the plasma of patients, which could be useful in prophylactic and therapeutic treatments. Moreover, we discuss on the development and isolation of Abs from different sources (hybridomas production, the generation of nanobodies, and the recombinant production of fully humanized mAbs) against different SARS-CoV-2 targets, in an integrative form. This review also incorporates a comprehensive view of the challenges that faces the cell factories at an industrial level to produce therapeutic Abs and their formats, guaranteeing the corresponding quality, efficacy and safety attributes in the bioprocess. Due to the importance of certain references, 18 preprints were considered. 


\section{The immune response and physiopathology of COVID-19}

COVID-19 is highly contagious, and oral-respiratory droplet contamination as well as aerosols, have been implicated in its transmission $[54,55]$. A wide spectrum of associated clinical symptoms have been described, such as gastrointestinal issues, diarrhea, shortness of breath, headache, sore throat, cold, breathing difficulties, myalgia, nasal congestion and inflammation of the mucous membranes, and central nervous system injuries [56], and patients present with asymptomatic to severe infections, or even succumb to the disease [57]. There is an important relationship between the COVID-19 severity and activation/suppression of the immune response elements. SARS-CoV-2 is a virus with the ability to generate an acute and destructive inflammatory response affecting the tissues and various cell types that express the hACE2 receptor $[10,58,59]$. hACE2 is a type I membrane protein present in the human organs, including the lungs, heart, kidney, and intestine [60]. The inflammatory response is induced by different immunological mechanisms associated with the innate and adaptive immune responses.

\section{Innate immune response against SARS-CoV-2 infection}

The innate immune response to SARS-CoV-2 is characterized by not only the activation of epithelial cells, but also the hyperactivity of macrophages. In the presence of the virus, macrophages and respiratory epithelial cells have the ability to release proinflammatory and inflammatory mediators by activating the inflammasome, and pattern recognition receptors induced by virus pathogenassociated molecular patterns (PAMPs) [61]. RNA from different viruses, such as CoVs, acts as a PAMP that can be detected by various toll-like receptors (TLRs), such as TLR3, TLR7, TLR8, and TLR9 [62], activating the nuclear factor kappa light chain enhancer of activated $B$ cells $(\mathrm{NF}-\mathrm{kB})$ pathway and proinflammatory cytokines [61]. During COVID-19 infection, it has been observed that monocytes have a relevant contribution in the progression of the disease towards severe manifestations, because the systemic profiles of cytokines in patients are similar to that in some of the syndromes, such as macrophage activation syndrome [63], or cytokine storm [64, 65]. This immune response is related to a high production of cytokines (IL-6, IL-7, and TNF- $\alpha$ ) and inflammatory chemokines, including CCL2, CCL3, and CXCL10, as well as the IL-2 receptor $\alpha$-chain in the soluble form $[64,66]$. Multiple organ failures and complications such as acute respiratory distress syndrome (ARDS), which

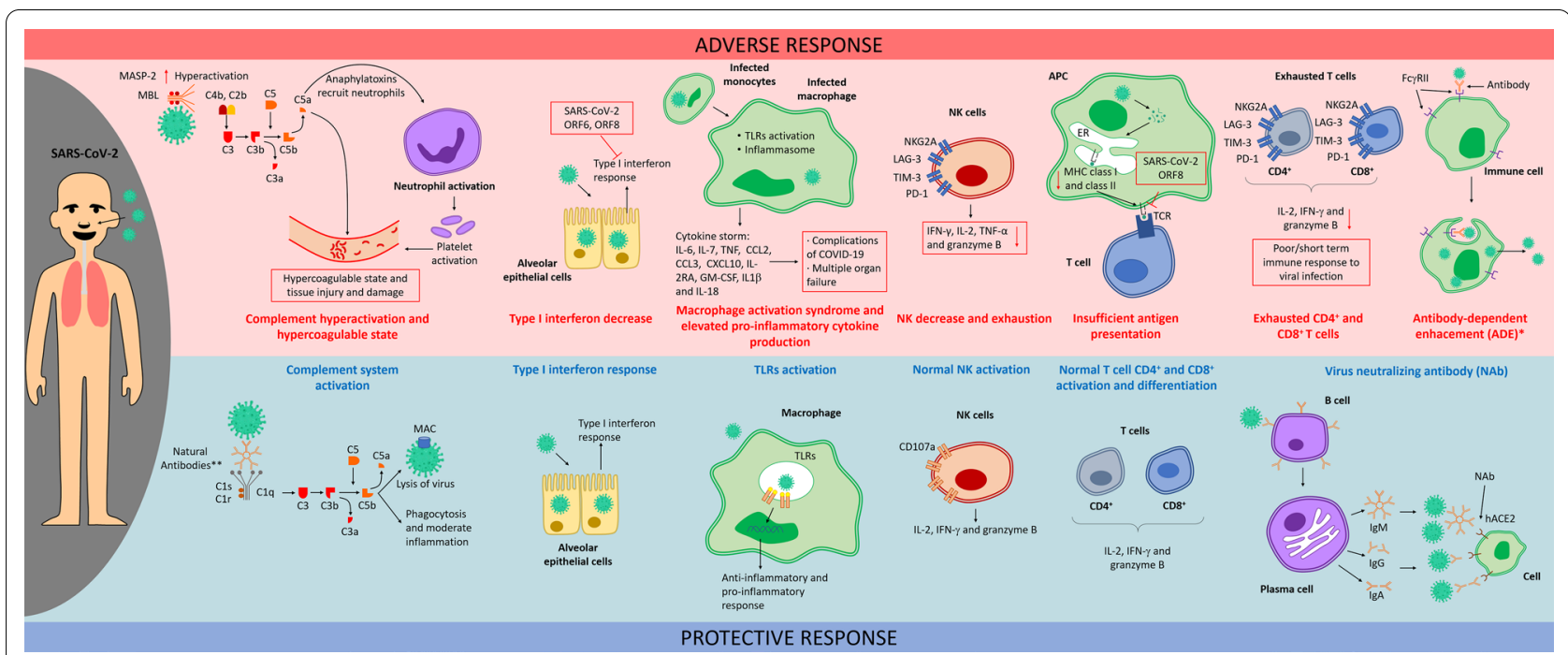

Fig. 1 Mechanisms in adverse and protective immune response for SARS-CoV-2. Upper panel (red). Adverse immune response in the presence of SARS-CoV-2 include mechanisms like complement hyperactivation and hypercoagulable state, excessive macrophage migration, macrophage activation syndrome, NK exhaustion, insufficient antigen presentation, exhausted $\mathrm{CD} 4^{+}$and $\mathrm{CD} 8^{+} \mathrm{T}$ cell and antibody-dependent enhancement (ADE) *This response has been described by in vitro models. Lower panel (blue). Protective immune response is characterized by complement system activation trough IgM natural antibodies (** this has been suggested as an initial barrier for SARS-CoV-2 infection), TLRs activation, NK and T cell normal activation and antibody virus neutralization by B cells. APC antigen presenting cell, ER endoplasmic reticulum, FcgRll receptor II for the Fc region of immunoglobulin G, GM-CSF Granulocyte-macrophage colony-stimulating factor, MAC membrane attack complex, MBL mannan-binding lectin, MHC major histocompatibility complex, MSP mannose-associated serine proteases, Nab neutralizing antibody, TCRT-cell receptor, TLRToll-like receptor 
could cause the death in patients (Fig. 1, Additional file 1: Table S1), have been related with the systemic overproduction of cytokines $[65,67]$.

The role of macrophages can be deduced from the immune response noted in other $\mathrm{CoV}$ infections, such as that for SARS-CoV, which has an accessory protein open reading frame 8 (ORF8) that activates a family of PAMPs called nucleotide-binding domain and leucinerich repeat pyrin domain 3 (NLRP3) [68]. NLRP3 can form multiprotein complexes, termed "inflammasomes" that activate caspase- 1 , which leads to the maturation of proinflammatory cytokines (IL-1 $\beta$ and IL-18), and induction of pyroptosis [69]. Moreover, this protein is present in SARS-CoV-2, and although its participation in the immune response has not been described, it is likely that NLRP3 could be associated with the aberrant activation of macrophages and elevated levels of IL- $1 \beta$ and IL-18 in some of the patients with COVID-19 [70] (Fig. 1 and Additional file 1: Table S1).

Forty-two percent of patients with pneumonia due to COVID-19 present severe ARDS [71]. This is reflected by the macrophage infiltration in the lung tissues observed post mortem [72]. Several studies have reported that macrophage hyperactivation results in pathological effects; this led us to hypothesize that a balance between anti-inflammatory and proinflammatory activities may be related to a protective immune response (Fig. 1 and Additional file 1: Table S1).

In severe cases, there is a decrease in natural killer (NK) cell populations [73]. Moreover, in patients infected with SARS-CoV-2, their NK cell population have shown lower percentages of intracellular CD107a, IFN- $\gamma$, IL-2, TNF- $\alpha$, and granzyme B compared with that in healthy subjects, and an exhaustive phenotype characterized by the overexpression of NK group 2 member A (NKG2A) [74]. An inhibitory receptor related to the dysfunctional NK cell phenotype [75] has also been observed in chronic viral infections [74, 76] as well as in COVID-19 patients with other NK cell exhaustive phenotype molecules, such as lymphocyte-activation gene-3 (LAG-3), programmed cell death protein 1 (PD-1), mucin domain-3 (TIM-3), and T-cell immunoglobulin [77] (Fig. 1 and Additional file 1: Table S1).

Another element of the innate immune response participating in COVID-19 pathophysiology is the complement system, which can be activated by an antibody-independent mechanism, termed the "lectin pathway". This mechanism uses, among other proteins, mannan-binding lectin-associated serine protease 2 (MASP-2), which can generate fragments of complement components, such as C5a that are potent mediators of inflammation and chemoattractants for neutrophils and monocytes. Since the SARS-CoV-2N protein can activate
MASP-2 [78], it may lead to the hyperactivation of the complement system that can cause significant damage, specifically damage related to neutrophil migration and activation in the lung tissues [79], and lead to hypercoagulation, as observed in critical patients [78]. Proteins of the complement system can also participate in coagulation [80] (Fig. 1 and Additional file 1: Table S1). Remarkably, MASPs have been shown to cleave prothrombin into thrombin [81]. The C5a receptor in neutrophils leads to the induction of the blood coagulation cascade [82], and C5b-9 stimulates procoagulant activity through platelet prothrombinase [83]. Some studies have suggested the potential SARS-CoV-2-specific antiviral effects of natural IgM Abs against A blood group produced by B1, in a complement-dependent manner, thereby proposing natural Abs as an initial barrier to infection and speculating a relationship between the reduced antibody diversity present in older patients [84] with severe illness [85] (Fig. 1 and Additional file 1: Table S1).

It has been suggested in different animal models infected with other viruses that an acute lung injury can be caused due to monocyte activation through mechanisms that could occur in SARS-CoV-2 infection. For example, viruses such as $\mathrm{H} 5 \mathrm{~N} 1$ avian influenza and SARS-CoV can activate macrophages by oxidative stress in a murine model [86, 87]; IgG anti-SARS-CoV S protein immune complexes can polarize the macrophage response into an inflammatory response in macaques [88].

Type I and III IFNs can control viral infection [89], but delayed interferon signaling in SARS-CoV-2 infection is related to robust virus replication and severe complications [90]. The decrease in IFN production is associated with ORF6, ORF8, and nucleocapsid proteins that inhibit the type I IFN signaling pathway [70] (Fig. 1 and Additional file 1: Table S1).

\section{Effective adaptive immune response against SARS-CoV-2 infection}

In COVID-19 the immune response associated with lymphocytes present heterogeneity as human diversity, but in many cases correlates with the severity of the disease. In adaptive cellular immune response patients with COVID-19 show a dramatic reduction in total $\mathrm{T}$ cells, which is negatively related to patient survival; these $\mathrm{T}$ cells express exhaustive signatures, such as PD-1, TIM-3, and LAG-3 [91, 92], all of which are immune-inhibitory factors [93, 94]. Evidence shows that $\mathrm{CD} 8^{+} \mathrm{T}$ numbers are low in patients with severe COVID-19 compared with less severe cases $[95,96] . \mathrm{CD}^{+} \mathrm{T}$ cells also express exhaustive-type cell phenotypes similar to NK cells (high expression of NKG2A and low expression of intracellular CD107a, IFN- $\gamma$, IL-2, TNF- $\alpha$, and granzyme B+) [74, 
97]. In addition, the $\mathrm{T}_{\text {reg }}$ and $\mathrm{CD} 4^{+} \mathrm{T}$ memory lymphocyte counts are reduced $[56,73,96]$. In the same sense, older patients with some comorbidity had a higher number of activated virus-specific $\mathrm{CD} 4^{+} \mathrm{T}$ cells compared to patients who had fewer risk factors. Moreover, these cells show an increase in IL-2 secretion and a diminishing in the IFN- $\gamma$ production [98]. Furthermore, lymphopenia has been associated with an increase in mortality [99], this probably caused by the infection of SARS-COV-2 to lymphocytes, which express hACE2 [100]. In addition, exhaustion of lymphocytes, has been observed in severe cases [101]. While in mild disease, an increased number of active $\mathrm{CD} 8^{+} \mathrm{T}$ cells and greater clonal expansion has been observed [101], as well as more IFN- $\gamma$-producing $\mathrm{T}$ helper 1 (TH1) cells. Notably, in recovered patients a strong memory $\mathrm{T}$ cell response in peripheral blood has been detected, being wider and intense in patients with severe condition compared to mild cases [102]. As well as the COVID-19 recovered patients have virus-specific memory $\mathrm{CD} 4^{+} \mathrm{T}$ and $\mathrm{CD} 8^{+} \mathrm{T}$ cells [103], which could be an indicative of protective immunity (Fig. 1, Additional file 1: Table S1).

Other cell populations, such as plasmacytoid dendritic cells and $\gamma \delta \mathrm{T}$ cells, have been reported to be almost depleted in SARS-CoV-2 infection [77]. Regarding antigen $(\mathrm{Ag})$ presentation for $\mathrm{T}$-cell activation, the ORF8 protein of SARS-CoV-2 can interact with the major histocompatibility complex class I (MHC-I) molecule, causing its downregulation and provoking the conjugate internalization to lysosome for its further degradation, avoiding the Ag presentation, being proposed as a via of immune evasion through ORF8 [104]. Furthermore, there is also evidence of downregulation of at least eight genes encoding MHC-II molecules in peripheral monocytes isolated from ventilation-dependent patients, relative to that in healthy subjects [77] (Fig. 1 and Additional file 1: Table S1). In contrast, the humoral arm of the adaptive response may facilitate, on rare occasions, the entry of viruses into host cells and enhancement of viral infection by a process independent of their specific cell receptors, known as "antibody-dependent enhancement (ADE)" [105, 106]. ADE comprises the production of subneutralizing or non-neutralizing Abs with a paradoxical effect associated with the virus-antibody interaction, with Fc receptors on different immune cells improving viral infection and replication $[107,108]$. This event has been described to be related to other CoVs, such as MERS-CoV, SARS-CoV, and feline CoVs [88-112]. However, in the case of SARS-CoV-2, this association has not been demonstrated in patients [113]. Nevertheless, there is evidence from in vitro models that show ADE promoted by Abs isolated from severely affected patients' plasma, relating to the FcyRII engagement [114] (Fig. 1 and Additional file 1: Table S1). Hence, ADE should be monitored in vaccination or therapeutic strategies against SARS-CoV-2 infection.

The controversy about the exacerbation of the disease and the appropriate response to resolve COVID-19 is still under discussion. However, hospital patients coincide in an insufficient or excessive immune response, compared to those individuals without serious consequences. This remarks that the set of innate and adaptive responses and their balance is important for a favorable progression, being highlighted that the humoral immune response points out that specialized neutralizing antibodies are the most important molecules for the protection against infection.

\section{Abs and their isotypes}

Dating back to the 1790s, Abs have been described as a protective substance in the serum after vaccination [115, 116]. Abs are used by the immune system to identify and neutralize elements, such as bacteria and viruses [117]. Abs are composed of proteins (82-96\%) and carbohydrates (4-18\%), and are divided into five immunoglobulin isotypes (IgG, IgA, IgM, IgE, and IgD), which differ in structure, abundance/distribution, specificity, and halflife [118].

Seric IgA is present in the plasma, and its secreted form (sIgA) is present in the mucous membrane, tears, and saliva, which prevents the colonization of pathogens in the respiratory, gastrointestinal, and urogenital tracts [119]. The sIgA is capable of inducing the synthesis of IL-6, IL-8, monocyte chemoattractant protein-1 (MCP1 ), and the granulocyte-macrophage colony-stimulating factor (GM-CSF) in the lung fibroblasts [120], which leads to hypothesizing its participation in severe cases of COVID-19 [121]. IgD is an antigen receptor localized at the surface of different B-cells, and its expression is balanced with IgM depending on the antigens sensed $[122,123]$. The secreted IgD is produced by mucosal B cells such as plasmablasts or plasma cells and improves mucosal homeostasis and prepares basophils and mast cells to protect the system against antigens, producing cytokines [122]. IgE has antiparasitic activity and responds to allergens, releasing histamine from mast cells and basophils [124]. IgM is also an Ag receptor in B cells and is the first to be secreted during the primary humoral immune response, before IgG synthesis [117, 124]. IgG is the most prevalent isotype, specialized to recognize and neutralize Ags [125].

\section{Humoral response}

It is well recognized that the neutralizing humoral immune response is the main mechanism for preventing viral infections [126]. Particularly, antibody-mediated 
responses against SARS-CoV-2, as well as their kinetics have been described in COVID-19 patients. The appearance of IgM, IgA, and IgG that recognize SARS$\mathrm{CoV}-2$ has been determined [127]. The seroconversion of patients with COVID-19 is attained following the onset of symptoms, producing IgM, IgA, and IgG [127, 128]. IgM accumulation is observed within 7 days post symptom onset (PSO), which is useful as a marker of acute infection. In contrast, IgA titer increases principally between 8 and 21 days PSO [127]. Importantly, the median time of IgG appearance has been recorded as 14 days PSO [127]. Hence, the detection of anti-SARS-CoV-2 Abs IgM and IgG is a diagnostic. However, the IgG and IgM levels are found to be widely variable, and no correlation between the $\mathrm{Ab}$ titers and clinical characteristics of the patients has been found [128].

The response of serum IgA against the $\mathrm{S}$ protein is detectable from 6 to 8 days PSO, with a mean period of 13 days PSO [121], followed by attainment of a peak on days 20-22 and maintenance for at least 40 days [129]. Furthermore, patients with COVID-19 establish the seroconversion of IgM and IgG that recognize mainly $\mathrm{N}$ and $\mathrm{S}$ (RBD) proteins, within 20 days PSO (median, 13 days PSO) [128]. A correlation has been observed between the increase in serum blood concentrations of IgA and IgG anti-S proteins and decrease in the viral counts, as well as the time between the onset of symptoms and admission to the intensive care unit. Moreover, a significant relationship between the serum titers of anti-S IgA and IgG and the survival of patients in a critical condition has been demonstrated [130]. In addition to neutralization, Abs can result in antiviral protection through other mechanisms, like antibody-dependent cell cytotoxicity (ADCC) resulting from Fc $\gamma$ RIIIa cross-linking in NK cells, antibody-dependent phagocytosis (ADCP) mediated by mononuclear and granulocyte phagocytes that bind to antibody-coated viruses through different Fc receptors, and complement activation by the classical route with the participation of IgM and IgG [131]. However, sometimes these same mechanisms can enhance the pathogenic condition, as previously described $[107,108]$. In the case of COVID-19, there are studies that demonstrate that the plasma of convalescent patients contains Abs capable of mediating ADCC, phagocytosis, and complement activation [132].

\section{Insights from $A b$ therapeutic strategies against SARS-CoV-2 infection Immunoglobulins}

Immunoglobulins are heterodimeric proteins comprising two identical $55-\mathrm{kDa}$ heavy $(\mathrm{H})$ chains and two identical $25-k D a$ light (L) chains linked by inter-chain disulfide bonds between conserved cysteine residues (Fig. 2)
[133]. The evaluation of the immune response in patients infected with SARS-CoV-2 is of great importance to understand the production of Abs. One study showed that 13 of 14 patients presented IgG1 anti-S-RBD, and in two patients, the presence of IgG3 was observed, while IgG2 was not found [134]. Immunoglobulins from patients with non-severe and severe COVID-19 have affinity for the $S$ protein or RBD that could block its interaction with hACE2, thereby preventing virus replication [16, 17, 32, 134-138]. An IgM response against the $\mathrm{N}$ protein, with a change in isotype to IgG after 15 days has been observed [13]. Although the titers of neutralizing Abs against SARS-CoV-2 in the human plasma decrease over time, these remain for at least three months until seroconversion [139].

A variety of anti-S or anti-RBD immunoglobulins generated from low somatic mutations are consistent with acute infection [13, 16, 17, 135, 140-144] due to low maturation of the affinity of Abs produced by B lymphocytes [17]. The neutralizing Abs have different epitopes, but many of them share the heavy-chain coding genes originating from similar germ lines of $\mathrm{V}$-segments belonging to the VH3 family (VH3-23, VH3-30, VH3-53, or VH366), as well as VH169, VH2-70, and VH5-51 [16, 32, $135,136,138,140,142,144,145]$. The light chains are preferably encoded by KV1-5, KV1-17, KV1-33, KV139, KV3-15, KV3-20, KV2-28, LV2-14, LV3-21, LV1-40, LV2-23, and LV6-57, among others [140, 142, 146]. Of note, these light chains predominantly pair with the long CDR H3 segment in the RBD region (15 amino acids or longer) $[28,135,136,138,142,145]$. Whereas the other light chains pair with the short CDR H3 segment, which is $7-11$ amino acids long $[16,32,135,136,142,145,146]$.

\section{Convalescent plasma therapy: one of the ways to fight COVID-19}

The implementation of the use of convalescent plasma (CP) has been a strategy to confer immunity or to treat individuals who acquire COVID-19. CP is collected from patients with neutralizing Abs after recovery and used to generate passive immunization [147-162].

The treatment involves collection of plasma from recovering patients, i.e., those who have faced an infectious disease and been cured successfully (known as convalescent patient), with the intention for it to be administered to recipient patients who have not yet developed an effective adaptive immune response (Fig. 3a) [163, 164]. The main objective of this alternative treatment is to reduce the viral load (viremia) in the recipient by the action of neutralizing Abs produced by the donor, which can occur between 10- and 14-days post infection $[165,166]$. A crucial factor for the success of CP therapy is the selection of donors, since one of the main 


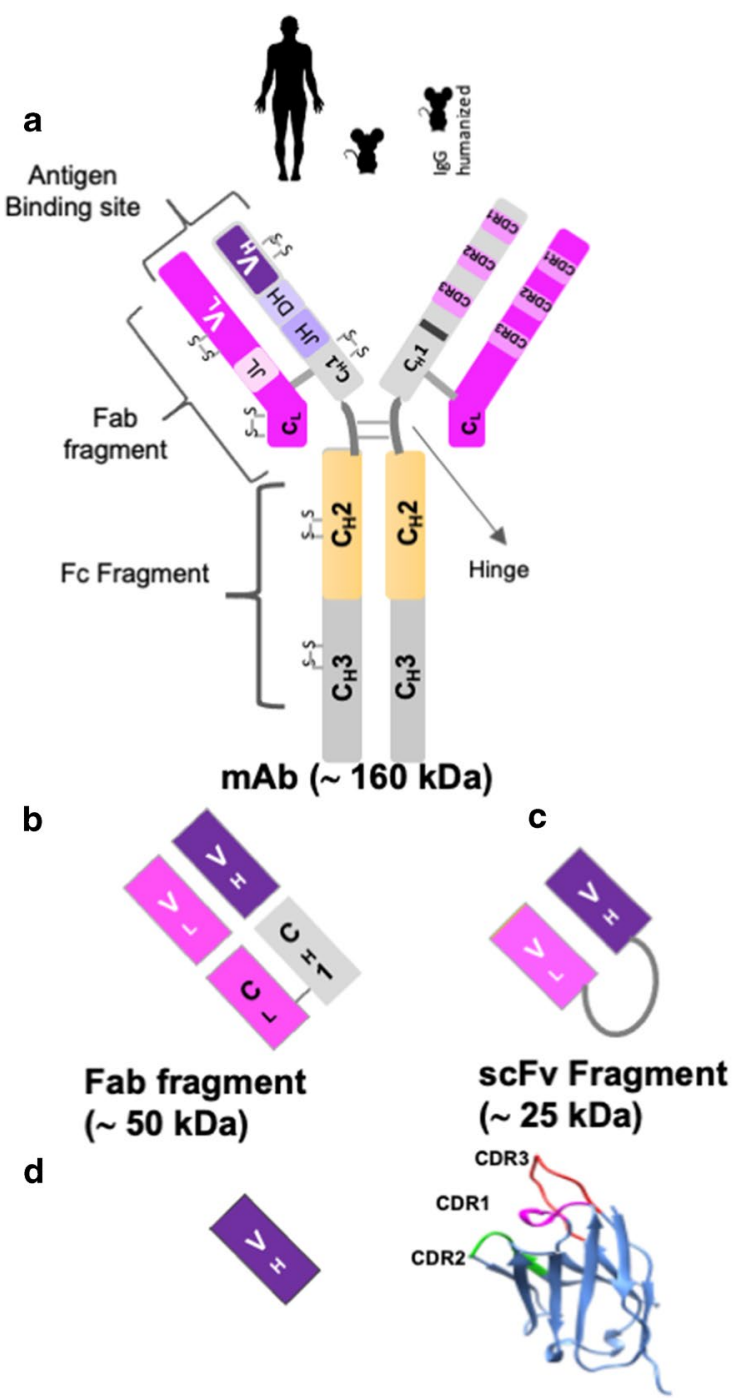

Single Domain Antibody ( 15kDa)

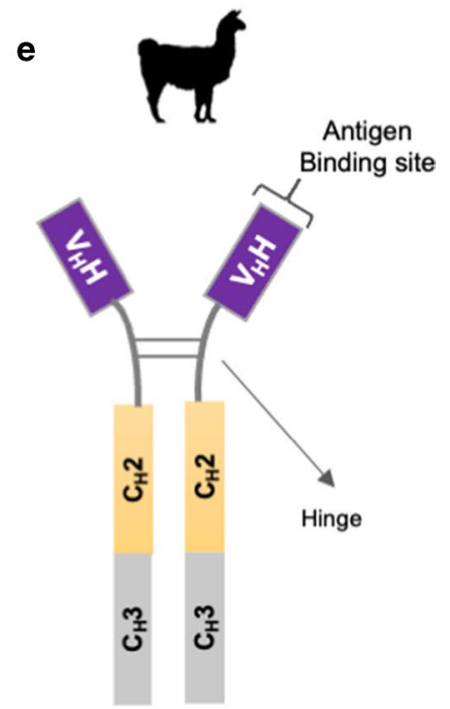

Heavy-chain antibody $(\sim 80 \mathrm{kDa})$
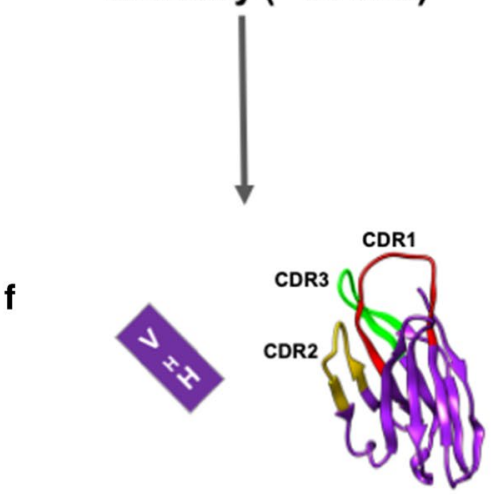

Nanobody (> 15 kDa)

Fig. 2 Diagram of antibodies and their respective fragments, from sources such as human, mouse, genetically humanized mouse, and alpaca. a mAb general view fragment antigen-binding region composed of two heavy and two light chains, disposed in Fab fragment and the fragment crystallizable $(\mathrm{Fc})$ which consists of constant heavy chains $\left(\mathrm{C}_{\mathrm{H}} 2\right.$ and $\left.\mathrm{C}_{\mathrm{H}} 3\right)$. The variable region formed by two arms which bind to antigen through complementary determining regions (CDRs). $\mathbf{b}$ Fab fragment is formed by the light chain $\left(V_{L}\right.$ and $\left.C_{L}\right)$ and by the heavy chain's variable $\left(V_{H}\right)$ region and a portion of its constant $\left(C_{H} 1\right)$. c A single-chain variable fragment ( $s c F V$ ) comprises the fusion of the $V_{H}$ and $V_{L}$ of immunoglobulins, connected by a linker peptide. $\mathbf{d}$ Single domain antibody (nanobody) consists of a monomeric variable domain $\left(V_{H}\right)$ of a heavy-chain antibody of a common IgG. e Antibodies from Camelidae or heavy-chain antibodies, presenting a variable region of a heavy $c h a i n\left(V_{H} H\right)$ and do not present light chains. $f$ The $\mathrm{V}_{\mathrm{H}} \mathrm{H}$ (Nanobody) derived from heavy-chain only antibodies have a longer CDR3 loop compared to $\mathrm{V}_{\mathrm{H}}-\mathrm{V}_{\mathrm{L}}$ domains in mAbs

problems that have been identified is the diversity of virus variants found in the population, and the neutralizing Ab titer in different plasma samples [167]. Thus, it is necessary to ensure that the plasma contains an appropriate concentration of neutralizing Abs, determine the antibody titer, and use a neutralization test in vitro with the virus variants. However, the potential side effects of $\mathrm{CP}$ therapy must be considered, particularly the serum incompatibility in recipients $[153,154,168-170]$. The CP therapy used to treat SARS-CoV and MERS-CoV patients in the critical stage of infection has been shown to reduce the viral load and death rate $[165,171]$. Based on the findings in the treatment of these diseases caused by other CoVs, CP from SARS-CoV-2-infected patients is administered as an experimental therapy in critically ill patients (Fig. 3a) (Additional file 1: Table S2). In addition, the use 


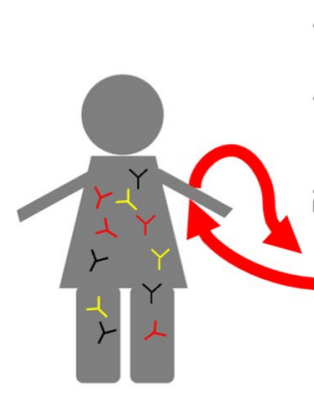

Convalescent plasma donors for COVID-19

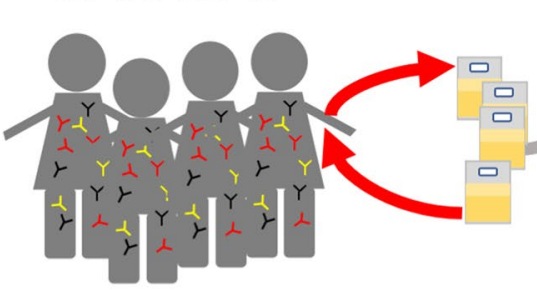

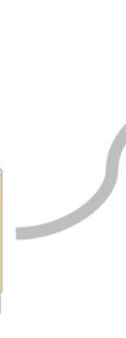

Convalescent plasma with Abs anti-SARS-CoV-2 and others

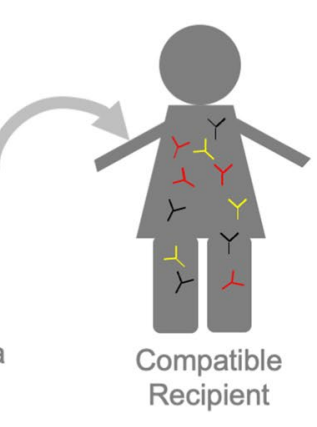

Industrial preparation

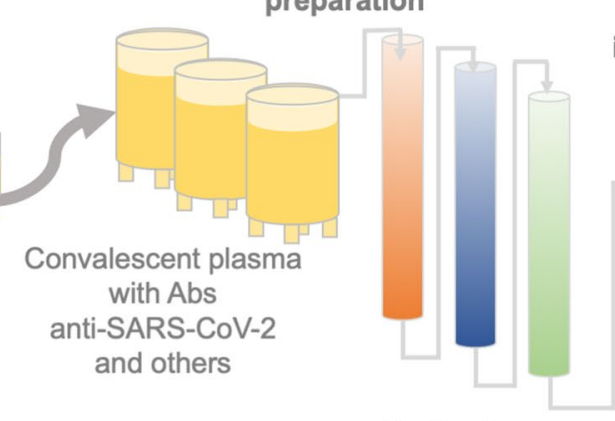

Purification
Hyperimmune anti-SARS-CoV-2 immunoglobulins

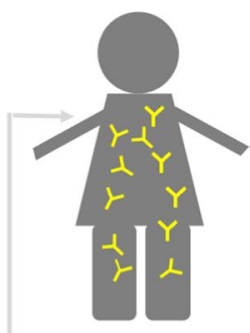

Compatible Recipient

Fig. 3 Methods of extraction and administration of Convalescent Plasma (CP). a a convalescent donor who has developed antibodies after recovering from the disease could donate plasma (usually through plasmapheresis) that includes antibodies against SARS-CoV-2 for direct transfusion and other antibodies (passive immunity) to patients with severe symptoms of the disease. $\mathbf{b}$ plasma from a group of donors could be used to identify and purify specific antibodies against SARS-CoV-2, eliminating other antibodies and proteins, making this method an alternative for passive immunization

of polyclonal immunoglobulins and plasma derivatives isolated and purified from the blood of COVID-19 survivors has been discussed [172, 173] (Fig. 3b). CP administration in patients leads to an increment in IgG, IgM, and neutralizing Ab titers [147, 149, 150, 152], a decrease in short-term mortality in patients with severe respiratory failure [155] and hospital mortality, and the shortening of duration of admission in hospital for severely ill patients [156]. It is also suggested that CP treatment can be more efficient when it is administered to patients with no critical or life-threatening conditions $[148,160,162]$. CP therapy is accompanied by the supplementation of different medications, including antivirals, antibiotics, antifungals, corticosteroids, and anticoagulants [147-159], according to the patients needs, resulting in variations relative to the healthy subjects. Due to the simultaneous use of $\mathrm{CP}$ and other medications, it is inappropriate to determine the beneficial or adverse effects of $\mathrm{CP}$ therapy conclusively.

In a study administering CP to a group of 22 critically ill patients, the hospital mortality rate reduced by $55 \%$ compared with that observed in other studies (Additional file 1: Table S2), and the hospitalization length was reduced [156]. This is probably due to the high SARSCoV-2 Abs titer of plasma administered more than once [156]. However, this study represents a compassionate bias when applying therapy to critically ill patients with little possibilities of success [162], unlike the treatment outcomes reported in other studies [148, 150, 160, 162], which showed no positive effects in such patients. Nonetheless, a precise design of controlled studies, randomized trials, and a high number of subjects are paving the way to further assess the benefits of CP therapy $[152,153,156-158,161]$. It is important to mention that CP treatments depend on plasma collecting time. The neutralizing Abs from CP of COVID-19 patients are enriched between 31 and 35 days after the first symptoms presenting a higher neutralization titer [174], but decreases in titers over time (42 days after first symptoms) [175]. Hence, FDA recommends a minimum titer of neutralizing Abs of 1:160.

Importantly, the presence of different Abs with the ability to neutralize specific epitopes of the virus, as well as their biotechnological production and application as a life-saving therapeutic agent, still requires investigation. 


\section{Neutralizing Abs against SARS-CoV-2}

Due to their high Ag specificity and potency, Abs have been used for the treatment of different illnesses. Hence, identification and production of the best candidate Abs against the key epitopes of SARS-CoV-2 will be vital $[12,176]$. Therefore, different strategies have been used to capture and obtain neutralizing Abs from patients with COVID-19 [16, 46, 177-180], such as combinatorial display libraries, humanized mice, single $\mathrm{B}$ cell cloning, memory B cell immortalization, and B cell culture, until the production of recombinant antibody fragments [46, 181-183] in different formats (Fig. 2). In this sense, Abs have shown a neutralizing effect in vitro and in vivo [18] (Table 1, Additional file 1: Table S3), although their safety and efficacy in vivo, as well as their contributions in ADCC, antibody-dependent genotoxicity, and even antibody-dependent risks are under evaluation, and there is scarce information on attempts of production on an industrial scale.

\section{Targets and classification of Abs against SARS-CoV-2}

A variety of Abs targeting different epitopes of SARS$\mathrm{CoV}-2$ have been described, principally those against the $\beta$-coronavirus envelope (Table 1 , Additional file 1: Table S3), conformed more externally by $S$ protein $[19$, 177]. The $S$ protein is a highly glycosylated homotrimeric protein of $\sim 180-200 \mathrm{kDa}$ (Fig. 4). As an inactive precursor, each S protomer (1273 residues) comprises two functional regions that become active after cleavage by the human protease TMPRSS2 [9-11]. The S1 subunit (14-685 residues) triggers the invasion process by mediating virus binding to the N-terminal domain (NTD) of hACE2, while the S2 subunit (686-1273 residues) drives the fusion of the viral and cellular membranes (Fig. 4), similar to that noted for other CoVs $[9-11,184]$.

The S1 subunit is composed of two domains, the NTD (14-305 residues) bearing a galectin-like motif and an RBD (319-541 residues) having a core comprising five-stranded antiparallel $\beta$-sheets $(\beta 1-4$ and $\beta 7)$ connected to helices $(\alpha 1-\alpha 3)$ and loops. The receptorbinding motif (RBM) within the RBD interacts with hACE2 at the 446-505 residue segment (Fig. 4) [12, 185-187]. The three RBDs undergo a hinge-like conformational equilibrium change from a "down" or closed pre-fusion state to an "up" or open fusion-prone state [14, 36, 188-190]. In the pre-fusion conformation, each RBD contacts extensively with the other RBDs and its own intracatenary NTD partially burying the RBM. Therefore, hACE2 binding is only possible in the active S protein conformation, with RBDs in the "up" state [184, 188, 191-193].

The neutralizing anti-SARS-CoV-2 Abs isolated from $\mathrm{CP}$ often recognize the RBD, particularly the $\mathrm{RBM}$, and thus, interfere with the virus-hACE2 interaction and prevent viral particle entry into the target cell $[12,17$, $32,135,194]$. Approximately $78 \%$ and $70 \%$ of COVID19 CPs have been found to present anti-RBD and anti-S IgG, with those in hospitalized individuals having high neutralizing activities [142]. This interaction bias is due to the RBM being an immunodominant region [178] and the $\mathrm{RBD} /$ spike protein-based strategies used to isolate many of these Abs. To date, several dozen structures of different Abs bound to the isolated RBD or S protein have been resolved experimentally (Table 1 ). According to their mode of binding to the viral protein, they have been grouped into four classes [194] (Fig. 5, Table 1). Class 1 comprises the largest group of Abs. These are characterized by a short CDRH3 loop and a binding pose that resembles the angle of interaction with hACE2, largely overlapping the RBM (Fig. 5a). Thus, these Abs can only bind to the "up"-state RBDs. Class 2 comprises Abs that partially overlap with the hACE2 footprint and can recognize both "up"- and "down"-state RBDs (Fig. 5a, b). As with Class 1, the binding poses of Class 2 Abs show that the neutralization effect is due to direct competition with hACE2, consistent with the competitive binding assay findings. The ability of Class $2 \mathrm{Abs}$ to bind RBDs in both the conformations results from their different angles of interaction with hACE2, avoiding any steric hindrance with the other RBDs even in the "down" conformation. Class 2 includes Abs with a long CDRH3 loop. Interestingly, some Class 2 Abs simultaneously bind two RBDs. Different interaction patterns have been observed for these "quaternary Abs." For example, the long CDRH3 loop of the mAb C144 interacts with two "down"-state RBDs. In this way, three C144 Abs lock the $S$ protein in the pre-fusion conformation [194]. Additionally, of the three $\mathrm{C} 002 \mathrm{Abs}$ that bind to the $\mathrm{S}$ protein, one links the other two "down"-state RBDs, the second binds one "down"-state and one "up"-state RBD, while the third binds only the "up"-state RBD (Fig. 5b) [194].

Classes 3 and 4 include Abs that bind outside the RBM. Some of these Abs compete directly with hACE2 because of the relative proximity of their epitope to the RBM. In the case of the mAb EY6A, steric hindrance occurs because of collision with hACE2 glycans [13]. Other mAbs do not interfere with the binding of hACE2 to the same RBD to which it is bound, but rather with that to a neighboring RBD. Class 3 Abs recognize a solvent-exposed protein/glycan epitope in both "up"- and "down"-state RBDs (Fig. 5c). This epitope is highly conserved in Sarbecovirus clades 1, 2, and 3 [27, 195], making it more difficult for the viruses to develop escape mutations. Class 4 Abs bind cryptic epitopes that become accessible only in "up"-state RBDs (Fig. 5c). One of these epitopes is buried by the contact between "down"-state 


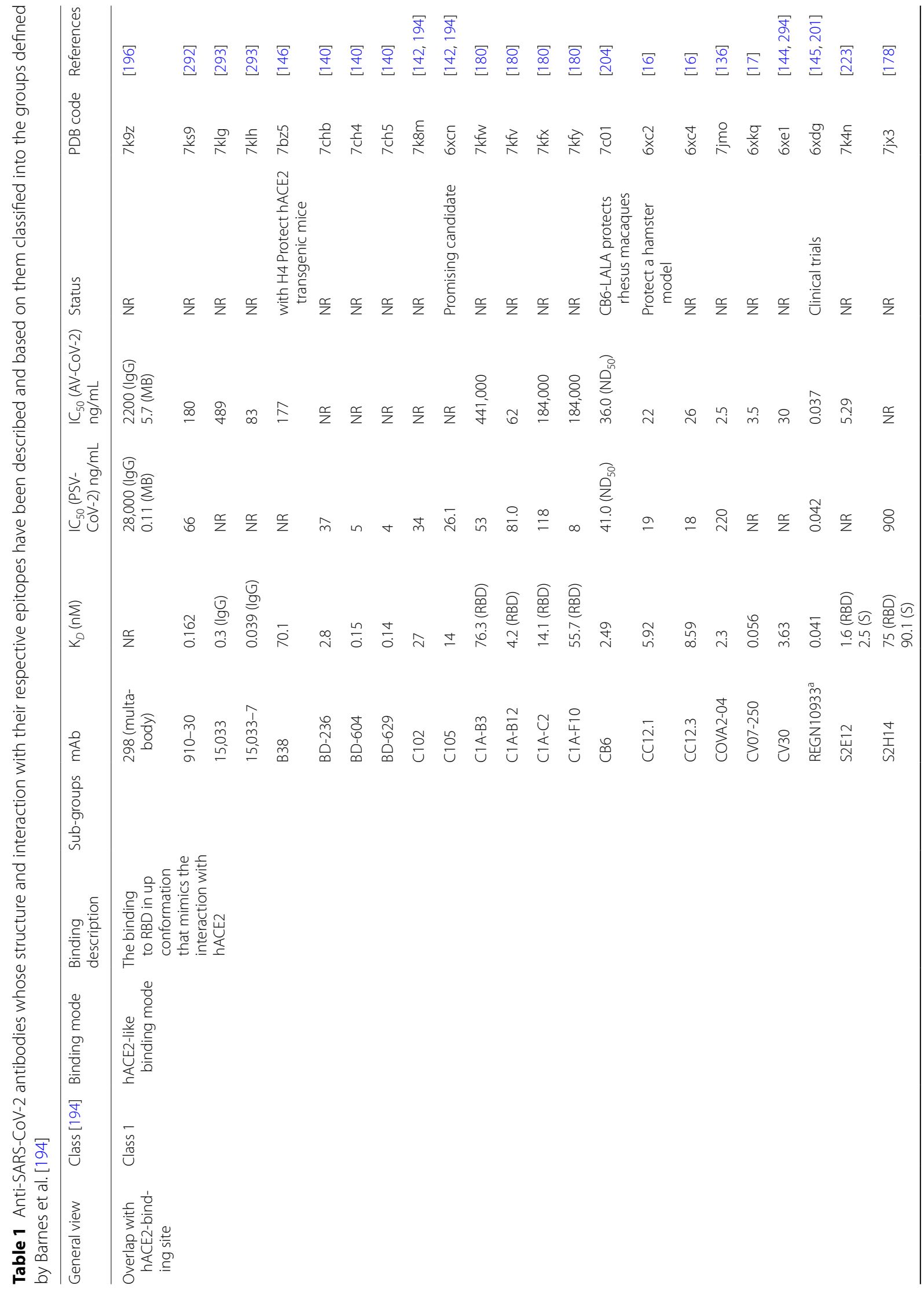




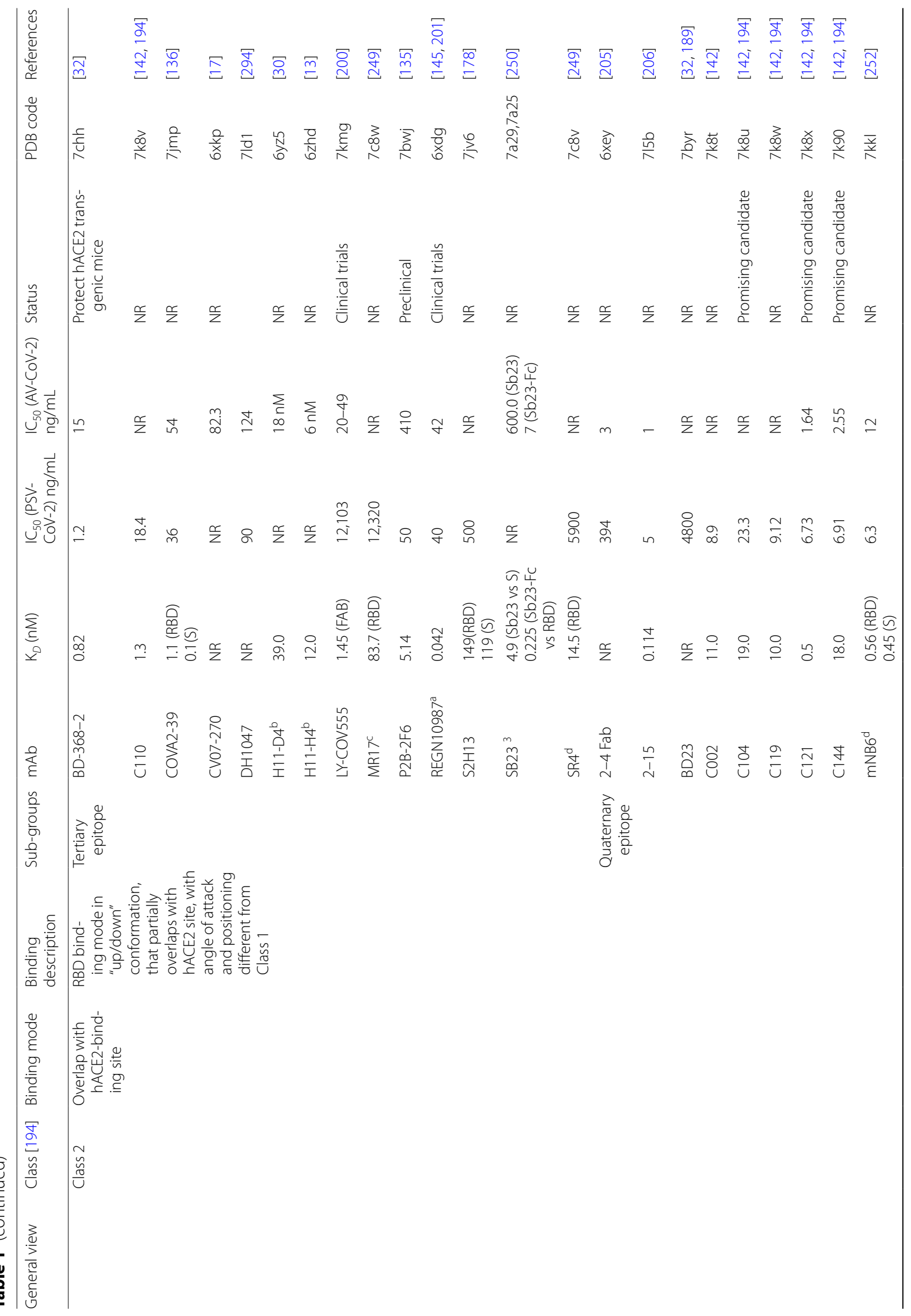




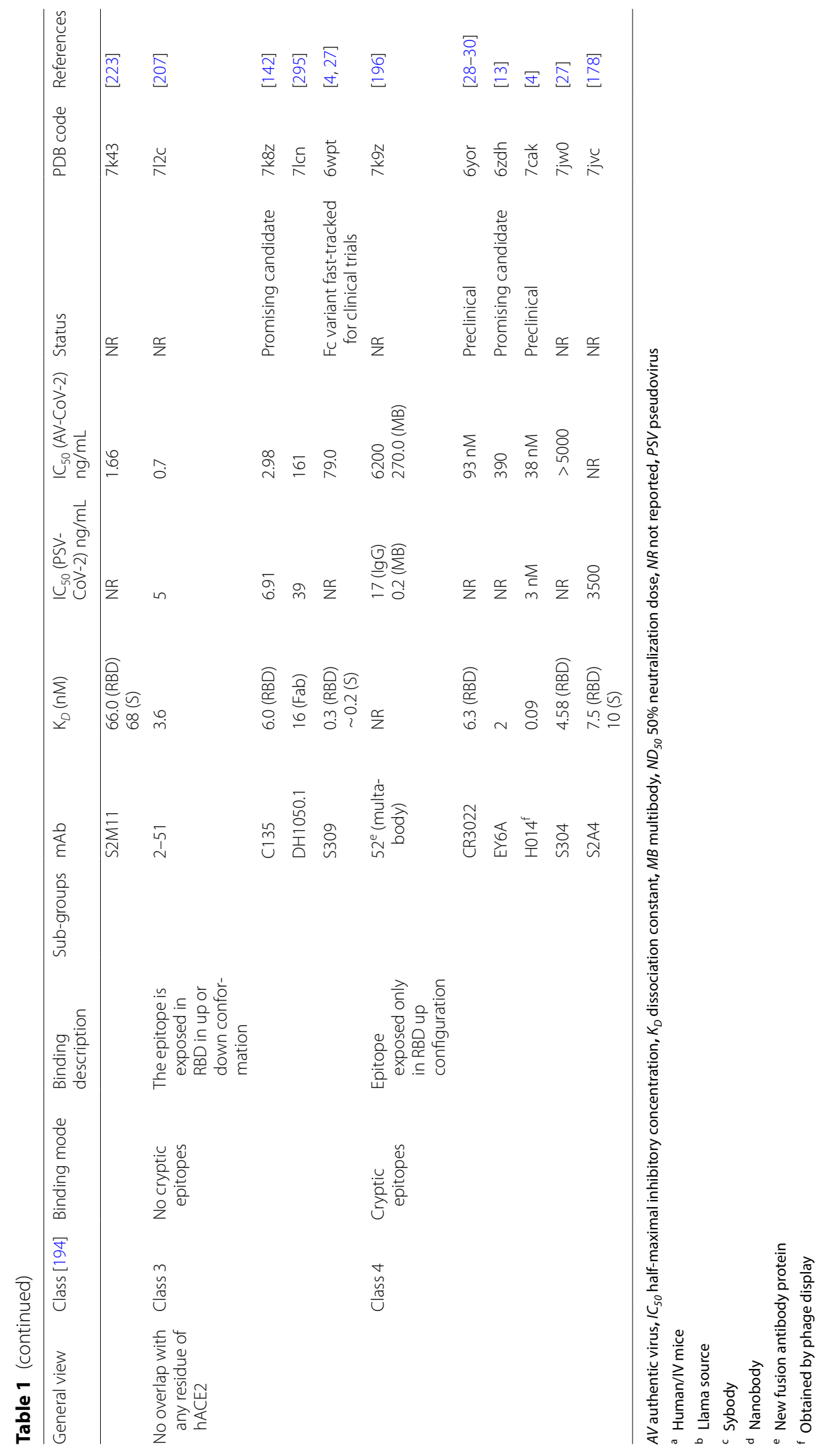




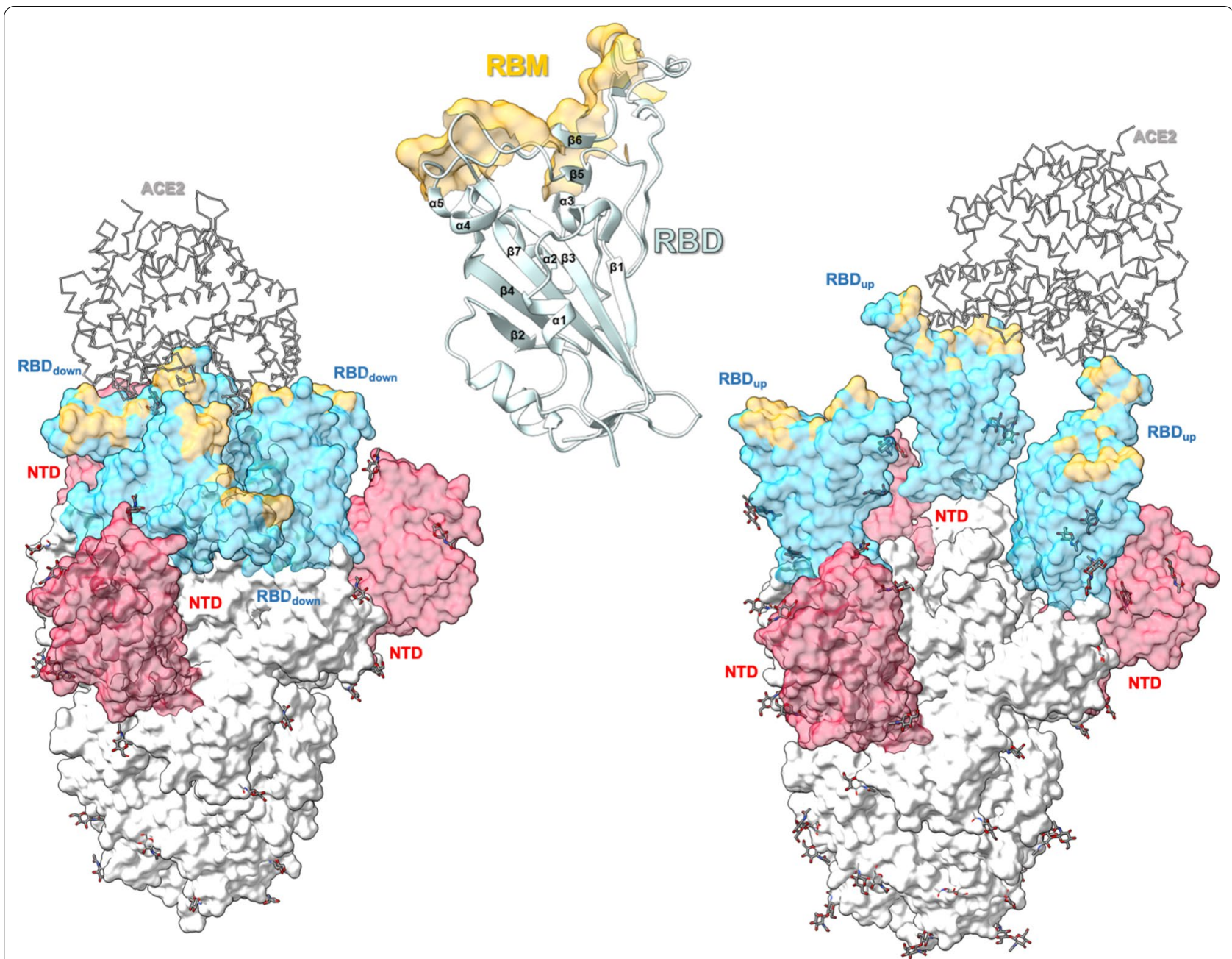

Fig. 4 Schematic representation of the homotrimeric S structure. The S protein conformations with all "down" (left) and all "up" (right) RBDs were generated with PDB files $7 \mathrm{k} 90$ and 7k4n, respectively. The RBM of RBD (center) is highlighted as an orange surface

RBDs. Therefore, Abs that recognize this epitope tend to affect the conformation and/or binding capacity of adjacent RBDs. An extreme case is represented by the $\mathrm{mAb}$ CR3022, which promotes destruction of the prefusion $\mathrm{S}$ protein trimer by perturbing the folding of both NTDs and RBDs [30, 33, 36]. mAb 52 recognizes a different cryptic epitope that is buried by the NTD in the pre-fusion conformation [196]. Although most Abs recognize epitopes consisting of only peptide moieties, some of them bind to protein/glycan moieties, sometimes with very high neutralizing potency $[197,198]$.

\section{Abs with cross-neutralizing activity against SARS-CoV-2}

The battery of neutralizing Abs described so far has been the result of intensified research using samples from various sources (Additional file 1: Table S3, S4). Since the RBDs of SARS-CoV and SARS-CoV-2 are 75\% identical in their primary sequence, only a relatively small number of Abs have shown cross-reactivity with these two Ags [12, 23]. The first set of anti-SARS-CoV-2 Abs was obtained from the blood of patients with anti-SARS-CoV Abs [13, 27]. In the initial studies, cross-neutralization was scarcely noted $[15,27,29,197,198]$. However, some anti-SARS-CoV Abs have shown cross-neutralizing activity against SARS-CoV-2 [12, 27]. For instance, the neutralizing Ab S309 obtained from B cells from a patient infected with SARS-CoV [27] and CR3022 IgG and Fab isolated from SARS-CoV CP present cross-reactivity with the SARS-CoV-2 RBD [28, 29, 36] (Additional file 1: Table S3). Another study has reported a 47D11 SARS$\mathrm{CoV}$-neutralizing $\mathrm{Ab}$ that also neutralized SARS-CoV-2 $[12,33]$. Data suggest a cross-neutralizing epitope shared between both the CoVs, which is directly related to some of the epitopes conserved in the RBD [194]. Despite this, 

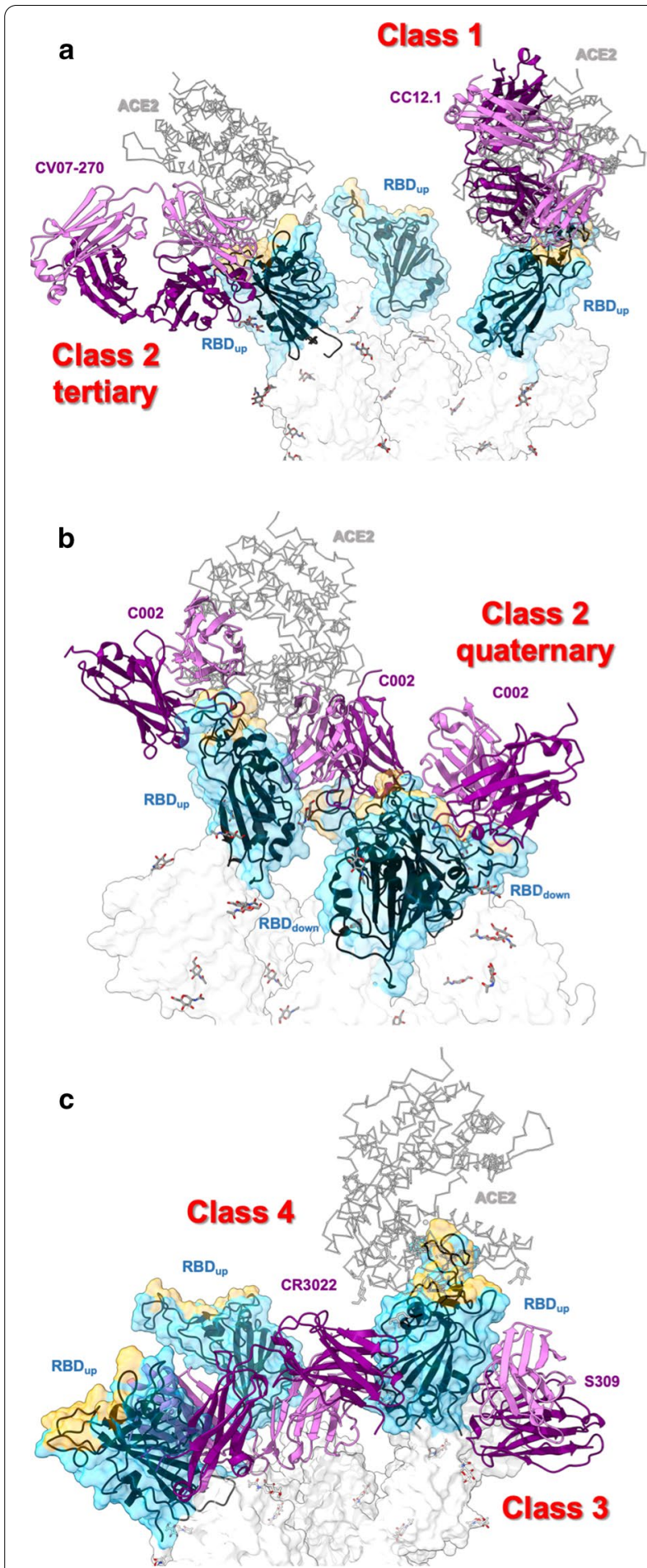

Fig. 5 Classes of antibodies according to the binding pose. Coordinates for antibodies CC12.1 (Class1), CV07-270 (Class 2 tertiary), C002 (Class 2 quaternary), S309 (Class 3), and CR3022 (Class 4) were taken from PDB files $6 x c 2,6 x \mathrm{kp}, 7 \mathrm{k} 8 \mathrm{t}, 6 \mathrm{wpt}$, and 6yro, respectively the Fab 2G12 developed as anti-HIV-1 presents cross reativity towards the $\mathrm{S} 2$ domain via glycan recognition, being of interest for the design of new therapies [199].

\section{Useful Abs with therapeutic or profilactic efficacy}

At least $80 \mathrm{mAbs}$ have been shown to block the interaction of the RBD with the hACE2 receptor in vitro, with a neutralizing effect against a pseudovirus or the authentic SARS-CoV-2 (Additional file 1: Table S3), and around 30 $\mathrm{mAbs}$ are under clinical trials (Additional file 1: Table S4) $[52,53]$. Among these, bamlanivimab (LY-CoV555) developed by Eli Lilly and Company (Indianapolis, IN, USA) has been granted emergency use authorization by the FDA [52, 200]. Similarly, two potent Abs, REGN10933/ casirivimab and REGN10987/imdevimab (Regeneron, Tarrytown, NY, USA), developed and recovered from VelocImmune $^{\circledR}$ (Regeneron), a genetically modified mouse with a human immune system, form part of the REGN-COV2 treatment, which is authorized by the FDA for emergency use [48, 52, 53, 145]. Each Ab recognizes the RBD at distinct sites, increasing the protection against and avoiding the escape of the virus by most of mutations $[145,201]$. The REGN-COV2 cocktail or LYCoV555 have demonstrated that decrease viral load and reduce the risk of progression to severe COVID-19 and hospitalization, each one with a particular dose [52, 202]. Although a recent study of LY-CoV555 did not demonstrate efficacy coupled with supportive care (remdesivir and, when indicated, supplemental oxygen and glucocorticoids) in hospitalized patients without end-organ failure, using a high dose (7000 mg per patient) [203].

Furthermore, several mAbs have demonstrated effectiveness in preclinical studies, and are currently under clinical trials of different phases (Additional file 1: Table S4). Some of these include sotrovimab, AZD7442, regdanvimab, DXP-593, DXP-604, etesevimab, STI1499/COVI-SHIELD, CT-P59, TY027, SCTA01, MW33, HFB30132A, BRII-196, BRII-198, ABBV-47D11, ABBV-2B04, COVI-GUARD (STI-1499), COVI-AMG (STI-2020), ADM03820, DZIF-10c, AD-20, JMB2002, LY-CovMab, C-144-LS, C-135-LS, COR-101, JS016, and HLX70 (Additional file 1: Table S4). The human Ab VIR7831 (or GSK4182136), developed by Vir Biotechnology Inc. (San Francisco, CA, USA) and GlaxoSmithKline (Brentford, UK), presents an epitope similar to that of S309 (Table 1, Fig. 5) and is presently under phase 3 evaluation [52, 53]. CT-P59 (Celtrium) and ADG20 (Adagio Therapeutics) is under phase $2 / 3$ clinical trial. The Abs AZD8895 and AZD1061, developed by Vanderbilt 
University and licensed by AstraZeneca (Cambridge, UK), TY027 (Tychan Pte., Ltd., Singapore), are in phase 3 clinical trial. In addition to etesevimab (LY-CoV016 or JS016) developed by Eli Lilly and Company, another related Ab CB6LALA is under phase 3 clinical trial [204]. Bamlanivimab (700 mg/dose) in combination with etesevimab (1400 mg/dose) won FDA authorization for emergency use. Other Abs, such as DXP-593 related to BD-368-2 and SCTA01, are close to completing phase 2 or phase $2 / 3$ clinical trials. Whereas Abs such as STI1499/COVI-SHIELD (Sorrento Therapeutics Inc., San Diego, CA, USA), BRII-96 (Brii Biosciences, Durham, NC, USA), BRII-98 (Brii Biosciencies), ABBV-47D11 (AbbVie, North Chicago, IL, USA), COVI-GUARD (STI1499; Sorrento Therapeutics Inc.), COVI-AMG (STI2020; Sorrento Therapeutics Inc.), MW33 (Mabwell Bioscience Co., Ltd., Shanghai), HFB30132A (HiFiBiO Therapeutics, Cambridge, MA, USA), and HLX70 (Hengenix Biotech Inc., Fremont, CA, USA) are under phase 1 clinical trials (Additional file 1: Table S4). Among the Abs in clinical trials, the characterization of Abs such as CB6-LALA and BD-368-2 [32, 204] has been fundamental. CB6-LALA is a neutralizing $\mathrm{mAb}$ isolated from B cells from the CP of patients with COVID-19, and it blocks the binding between the SARS-CoV-2 RBD and hACE2 through steric hindrance and competition for the interface amino acid interaction, without inducing conformational changes in the RBD. It has been proposed as a potential therapeutic agent against SARS$\mathrm{CoV}-2$ in rhesus macaques because it reduces the viral titer and infection [204]. This Ab has been modified via leucine-to-alanine mutations at residues 234 and 235 (LALA mutation) in the Fc region to diminish the possibility of Fc-mediated acute lung injury [204]. In addition, BD-368-2 effectively neutralizes the pseudovirus of SARS-CoV-2 and authentic SARS-CoV-2 $\left(\mathrm{IC}_{50}\right.$ of $1.2 \mathrm{ng} / \mathrm{mL}$ and $15 \mathrm{ng} / \mathrm{mL}$, respectively) [32] (Table 2). BD-368-2 binds the RBD in the "down" conformation, localizing between the NTD and RBD and adjacent to an RBD in the "up" conformation. Moreover, BD-368-2 can bind RBDs in the "up" and "down" conformations, to reach complete occupancy of the $\mathrm{S}$ protein trimer [140] (Table 1, Table 2). BD-368-2 can interact with the RBD in combination with CR3022 and S309 [27, 29]. Furthermore, BD-368-2 shows prophylactic and therapeutic efficacy (Additional file 1: Table S3) in hACE2 transgenic mice [32].

\section{Potent neutralizers mAbs against SARS-CoV-2}

At least 21 Abs published present a potent neutralizing effect against the pseudovirus or authentic SARS-CoV-2 infection, with an $\mathrm{IC}_{50}$ lower than $0.01 \mu \mathrm{g} / \mathrm{mL}$ (Table 2). Among these, CV07-250, BD-604, BD-629, COVA1-18,
CC6.29, COV2-2196 are Class 1 Abs (Table 2). Class 2 Abs such as BD-368-2, COV2-2130, COVA2-04, C119, C121, C144, COVA2-15, 2-15 and C002 are the most potent (Table 2). The Class $3 \mathrm{Ab} \mathrm{C135}$ and 2-51, and Class 4 Ab H014 present an elevated neutralizing effect (Table 2). The mAb 5-24 that binds the NTD, and Abs CV07-209, 2-15, 1-57, and 2-7 that interact with the RBD, also present potent neutralizing activities (Table 2). The diversity in amongst the potent neutralizing Abs is crucial, considering their probable combinational use to achieve rational therapeutic effectiveness, as well as their usefulness in reducing or preventing evasion by the present or future virus variants.

The Abs CV07-250 and CV07-209 have been isolated from the B cells of patients with COVID-19, with CV07-209 being the most potent mAb that neutralizes authentic SARS-CoV-2 ( $\left.\mathrm{IC}_{50}: 3.1 \mathrm{ng} / \mathrm{mL}\right)$ and CV07250 presenting close enough activity $\left(\mathrm{IC}_{50}: 3.5 \mathrm{ng} / \mathrm{mL}\right.$ ). The crystal structure of CV07-250 in complex with the SARS-CoV-2 RBD has been resolved at $2.55 \AA$ A. Prophylactic and therapeutic evaluations have shown CV07-209 to protect hamsters from SARS-CoV-2 infection [17]. CV07-250 (Class $1 \mathrm{Ab}$ ) binds the RBD, at a site overlapping with the hACE2-binding site, via an unusual light chain-dominated interaction. On the contrary, BD-604 and BD-629 (Class $1 \mathrm{Abs}$ ) also show a potent neutralizing effect against the SARS-CoV-2 pseudovirus with an $\mathrm{IC}_{50}$ of $5 \mathrm{ng} / \mathrm{mL}$ and $4 \mathrm{ng} / \mathrm{mL}$, respectively. Both Abs interact with the RBD, with the binding of BD-629 dominated by the heavy chain in comparison with that of BD-604 [140]. The crystal structures of BD-604 and BD-629 resolved at $3.2 \AA$ and $2.7 \AA$, respectively, show that they bind the RBD in a manner similar to that of other Class 1 Abs [140], such as C105 [142, 194] and CB6 [204] (Table 2).

A family of Abs obtained from the $B$ cells of patients with COVID-19, including 2-15, 1-57, 2-7, and 5-24, have been found to have potent neutralizing activities against authentic SARS-CoV-2 in vitro with an $\mathrm{IC}_{50}$ of $0.7 \mathrm{ng} / \mathrm{mL}, 8 \mathrm{ng} / \mathrm{mL}, 3 \mathrm{ng} / \mathrm{mL}$, and $8 \mathrm{ng} / \mathrm{mL}$, respectively $[205,206]$. The $1-57$, and $2-7$ Abs belong to Class 1 . The 5-24 and 2-51 Ab binds the NTD and exerts a powerful neutralizing effect $[205,207]$. The $2-15 \mathrm{Ab}$ (Class 2) has been evaluated in vivo in protection experiments using golden Syrian hamster as a model of SARS-CoV-2 infection. Virus challenge showed a reduction in infectious viral particle titers with $1.5 \mathrm{mg} / \mathrm{kg}$ of 2-15 [205].

The Abs COVA1-18, COVA2-04, and COVA2-15 are also obtained from B cells of patients with COVID-19, and these present strong competition for hACE2 with an $\mathrm{IC}_{50}$ against authentic SARS-CoV-2 of 7.0, 2.0, and $9.0 \mathrm{ng} / \mathrm{mL}$, respectively [136]. COVA1-18 appears to be a Class $1 \mathrm{Ab}$, and the cryogenic electron microscopy (cryo-EM) reconstructions reveal that COVA2-15 is 
Table 2 Antibodies with a potent neutralizing effect against pseudovirus or authentic virus SARS-CoV-2 infection

\begin{tabular}{|c|c|c|c|c|c|c|}
\hline $\begin{array}{l}\text { Name/ } \\
\text { class }\end{array}$ & Source & $\mathrm{K}_{D}(\mathrm{nM})$ & $\mathrm{IC}_{50} \mathrm{\mu g} / \mathrm{mL}$ & Target & Observations & References \\
\hline $\begin{array}{l}\text { CV07-250/ } \\
\text { C1 }\end{array}$ & B cells from C-CoV-2 & 0.056 & 0.0035 (AV-CoV-2) & RBD & $\begin{array}{l}\text { Reduced hACE2 binding and showed no } \\
\text { binding to murine tissue }\end{array}$ & [17] \\
\hline BD-604/C1 & B cells from C-CoV-2 & 0.15 & 0.005 (PSV-CoV-2) & RBD up & $\begin{array}{l}\text { BD-604 binds to RBD 19-fold higher } \\
\text { than BD- } 236 \text { and is more potent } \\
\text { against the SARS-CoV-2 pseudovirus, } \\
\text { compared to BD- } 236\end{array}$ & [140] \\
\hline BD-629/C 1 & B cells from C-CoV-2 & 0.006 & 0.004 (PSV-CoV-2) & RBD up & $\begin{array}{l}\text { Genes coding for BD- } 629 \text { are different } \\
\text { compared to BD-604. However, its } \\
\text { affinity and neutralization against the } \\
\text { SARS-CoV-2 pseudovirus are similar }\end{array}$ & [140] \\
\hline $\begin{array}{l}\text { CV07-209/ } \\
\text { C1 }\end{array}$ & B cells from C-CoV-2 & 0.056 & 0.003 (AV-CoV-2) & RBD & $\begin{array}{l}\text { Prophylactic and therapeutic efficacy in } \\
\text { golden Syrian hamsters. Therapeutic } \\
\text { mAb reduced signs of COVID-19, } \\
\text { although } 1 / 3 \text { animals presented mild } \\
\text { bronchopulmonary, pneumonia and } \\
\text { endothelialitis }\end{array}$ & [17] \\
\hline $\begin{array}{l}\text { COVA1-18/ } \\
\text { C1 }\end{array}$ & B cells from C-CoV-2 & $\begin{array}{l}0.03(\mathrm{~S}) \\
0.9 \text { (RBD) }\end{array}$ & $\begin{array}{l}0.008 \text { (PSV-CoV-2) } \\
0.007 \text { (AV-CoV-2) }\end{array}$ & RBD & $\begin{array}{l}\text { A strong competition with hACE2 was } \\
\text { observed, suggesting blocking hACE2 } \\
\text { is it mechanism of neutralization }\end{array}$ & [136] \\
\hline CC6.29/C 1 & B cells from C-CoV-2 & 1.2 & $\begin{array}{l}0.002 \text { (PSV-CoV-2) } \\
0.0071 \text { (AV-CoV-2) }\end{array}$ & RBD-A & mAb exhibited a potent neutralization & [16] \\
\hline $\begin{array}{l}\text { COV2- } \\
2196 / C 1\end{array}$ & B cells from C-CoV-2 & - & $\begin{array}{l}0.0007 \text { (PSV-CoV-2) } \\
0.015 \text { (AV-CoV-2) }\end{array}$ & $\mathrm{S} 2 \mathrm{P}_{\text {ecto }}$ open & $\begin{array}{l}\text { A strong competition with hACE2. Pro- } \\
\text { phylactic efficacy in rhesus macaques } \\
(50 \mathrm{mg} / \mathrm{Kg}) \text { and mice }(200 \mathrm{\mu g} \text { per } \\
\text { mouse) reducing lung disease. Thera- } \\
\text { peutic efficacy in mice }\left(20 \mathrm{mg} \mathrm{kg}^{-1}\right)\end{array}$ & [208] \\
\hline $\begin{array}{l}\mathrm{BD}-368-2 / \\
\mathrm{C} 2\end{array}$ & B cells from C-CoV-2 & 0.82 & $\begin{array}{l}0.0012 \text { (PSV-CoV-2) } \\
0.015 \text { (AV-CoV-2) }\end{array}$ & $\begin{array}{l}\text { RBD } \\
\text { "up/down" }\end{array}$ & $\begin{array}{l}\text { Changes the S trimer conformation } \\
\text { contributing to its neutralizing activity. } \\
\text { Prophylactic efficacy: IP } 20 \mathrm{mg} / \mathrm{kg} \\
\text { mAb } 24 \mathrm{~h} \text { before infection. Therapeutic } \\
\text { efficacy: IP } 20 \mathrm{mg} / \mathrm{kg} \text { of mAb } 2 \mathrm{~h} \text { after } \\
\text { infection into hACE2 transgenic mice }\end{array}$ & {$[32]$} \\
\hline $\begin{array}{l}\text { COV2- } \\
2130 / C 2\end{array}$ & B cells from C-CoV-2 & - & $\begin{array}{l}0.0016 \text { (PSV-CoV-2) } \\
0.107 \text { (AV-CoV-2) }\end{array}$ & S2P $\mathrm{P}_{\text {ecto }}$ closed & $\begin{array}{l}\text { Blocked the binding of SARS-CoV-2 to } \\
\text { hACE2. Prophylactic efficacy in rhesus } \\
\text { macaques ( } 50 \mathrm{mg} / \mathrm{Kg} \text { ) and mice } \\
\text { ( } 200 \mu \mathrm{\mu g} \text { per mouse) developing less } \\
\text { lung disease. Therapeutic }\left(20 \mathrm{mg} \mathrm{kg}{ }^{-1} \text { ) }\right. \\
\text { efficacy in mice }\end{array}$ & [208] \\
\hline C12-04/C2 & B cells from C-CoV-2 & $\begin{array}{l}2.3(\mathrm{~S}) \\
11.2(\mathrm{RBD})\end{array}$ & $\begin{array}{l}0.220 \text { (PSV-CoV-2) } \\
0.002(\mathrm{AV}-\mathrm{CoV}-2)\end{array}$ & RBD "up"/"down" & $\begin{array}{l}\text { Potent neutralizing } \mathrm{mAB} \text {, suggest the } \\
\text { blocks the engagement of } \mathrm{hACE} 2 \text { as a } \\
\text { main mechanism of neutralization }\end{array}$ & [136] \\
\hline C119/C2 & PMBC's from C-CoV-2 & 10.0 (RBD) & 0.009 (PSV-CoV-2) & RBD "up"/"down" & $\begin{array}{l}\text { It was proposed a quaternary interac- } \\
\text { tion with RBD in down conformation } \\
\text { adjacent to an "up" RBD, as well could } \\
\text { interacts between two adjacent down } \\
\text { RBD domains. Showed a binding pose } \\
\text { similar to REGN10987's }\end{array}$ & {$[142,194]$} \\
\hline $\mathrm{C} 121 / \mathrm{C} 2$ & PMBC's from C-CoV-2 & 0.5 (RBD) & $\begin{array}{l}0.0067 \text { (PSV-CoV-2) } \\
0.00164 \text { (AV-CoV-2) }\end{array}$ & RBD "up"/"down" & $\begin{array}{l}\text { Quaternary binding with RBD in down } \\
\text { adjacent to an "up" RBD was proposed, } \\
\text { and could interacts between two } \\
\text { adjacent down RBD, with a binding } \\
\text { pose similar to REGN10987's }\end{array}$ & {$[142,194]$} \\
\hline $\mathrm{C} 144 / \mathrm{C} 2$ & PMBC's from C-CoV-2 & 18.0 (RBD) & $\begin{array}{l}0.0069 \text { (PSV-CoV-2) } \\
0.0025 \text { (AV-CoV-2) }\end{array}$ & RBD "up"/"down" & $\begin{array}{l}\text { Quaternary binding, in the "down" RBD } \\
\text { conformation. different from C002, } \\
\text { C121, C119, C104 }\end{array}$ & {$[142,194]$} \\
\hline $\begin{array}{l}\text { COVA2-15/ } \\
\text { C2 }\end{array}$ & B cells from C-CoV-2 & $\begin{array}{l}0.6(\mathrm{~S}) \\
3.1 \text { (RBD) }\end{array}$ & $\begin{array}{l}0.008 \text { (PSV-CoV-2) } \\
0.009 \text { (AV-CoV-2) }\end{array}$ & RBD "up"/"down" & $\begin{array}{l}\text { A strong competition with hACE2 bind- } \\
\text { ing, binding RBD in "up" and "down" } \\
\text { conformations, while its epitope is } \\
\text { partially overlapped with the hACE2- } \\
\text { binding site }\end{array}$ & [136] \\
\hline
\end{tabular}


Table 2 (continued)

\begin{tabular}{|c|c|c|c|c|c|c|}
\hline $\begin{array}{l}\text { Name/ } \\
\text { class }\end{array}$ & Source & $\mathrm{K}_{D}(\mathrm{nM})$ & $\mathrm{IC}_{50} \mathrm{\mu g} / \mathrm{mL}$ & Target & Observations & References \\
\hline $2-15 / C 2$ & B cells from C-CoV-2 & 0.056 & $\begin{array}{l}0.005 \text { (PSV-CoV-2) } \\
0.0007 \text { (AV-Cov-2) }\end{array}$ & RBD "up"/"down" & $\begin{array}{l}\text { Exhibited high potency in neutralizing } \\
\text { in vitro, in a protection experiments } \\
\text { using golden Syrian hamster reduced } \\
\text { the infectious virus titres by } 4 \text { logs } \\
(1.5 \mathrm{mg} / \mathrm{kg})\end{array}$ & {$[205,206]$} \\
\hline $\mathrm{C002/C2}$ & PBMC from C-CoV-2 & 11 (RBD) & 0.009 (PSV-CoV-2) & RBD "up"/"down" & $\begin{array}{l}\text { Quaternary binding to "up/down" RBDs } \\
\text { like C121, but different to C144. Inter- } \\
\text { action with RBD in down conforma- } \\
\text { tion adjacent to an "up" RBD, probably } \\
\text { interacts between two adjacent } \\
\text { "down" RBD domains }\end{array}$ & {$[142,194]$} \\
\hline C135/C3 & PMBC's from C-CoV-2 & 6.0 (RBD) & $\begin{array}{l}0.016 \text { (PSV-CoV-2) } \\
0.0029 \text { (AV-CoV-2) }\end{array}$ & RBD "up"/"down" & $\begin{array}{l}\text { Three C135 Fabs bound with 2 "down" } \\
\text { and } 1 \text { "up" RBDs (interaction weakly } \\
\text { resolved), recognizing the glycosylated } \\
\text { epitope N343RBD, interacting with } \\
\text { R346 and N440, without steric hin- } \\
\text { drance between hACE2 / RBD }\end{array}$ & {$[142,194]$} \\
\hline $2-51 / C 3$ & B cells from C-CoV-2 & 3.6 & $\begin{array}{l}0.005 \text { (PSV-CoV-2) } \\
0.0007 \text { (AV-Cov-2) }\end{array}$ & NTD & $\begin{array}{l}\text { Potent neutralizing antibody against } \\
\text { PSV-CoV- } 2 \text { and AV-Cov- } 2 \text { in vitro }\end{array}$ & [207] \\
\hline $\mathrm{H} 014 / \mathrm{C} 4$ & phage display antibody library & 0.09 & $\begin{array}{l}3 \mathrm{nM}(\mathrm{PSV}-\mathrm{CoV}-2) \\
38 \mathrm{nM}(\mathrm{AV}-\mathrm{CoV}-2)\end{array}$ & RBD up class 4 & $\begin{array}{l}\text { hACE2-humanized mice injected IP } \\
50 \text { mg per kilogram either } 4 \mathrm{~h} \text { after } \\
\text { (one dose, therapeutic) or } 12 \mathrm{~h} \text { before } \\
\text { and } 4 \mathrm{~h} \text { after (two doses, prophylactic } \\
\text { plus therapeutic) with SARS-CoV-2 } \\
\text { infection. No lesions of alveolar epi- } \\
\text { thelial cells }\end{array}$ & [4] \\
\hline $5-24 / \mathrm{WO}$ & B cells from C-CoV-2 & & $\begin{array}{l}0.013 \text { (PSV-CoV-2) } \\
0.008 \text { (AV-CoV-2) }\end{array}$ & NTD & $\begin{array}{l}\text { nAb with high potency against AV-Cov-2 } \\
\text { in vitro }\end{array}$ & [205] \\
\hline $1-57 / \mathrm{WO}$ & B cells from C-CoV-2 & 0.056 & $\begin{array}{l}0.009 \text { (PSV-CoV-2) } \\
0.008 \text { (AV-CoV-2) }\end{array}$ & RBD & $\begin{array}{l}\text { mAb exhibited high potency in neutral- } \\
\text { izing AV-Cov-2 in vitro }\end{array}$ & [205] \\
\hline 2-7/WO & B cells from C-CoV-2 & 0.056 & $\begin{array}{l}0.010 \text { (PSV-CoV-2) } \\
0.003 \text { (AV-CoV-2) }\end{array}$ & RBD & $\begin{array}{l}\text { mAb exhibited high potency in neutral- } \\
\text { izing AV-Cov-2 in vitro }\end{array}$ & [205] \\
\hline
\end{tabular}

SARS-CoV Severe acute respiratory syndrome-coronavirus, SARS-CoV-2 respiratory syndrome-coronavirus 2, RBD Receptor binding domain, $P B M C S$ Fresh peripheral blood mononuclear cells, IP Intraperitoneally, PSV Pseudovirus, AV-CoV-2 authentic virus SARS-CoV-2, AV-CoV authentic virus SARS-CoV, SdAb single-domain antibodies, CPE Cytopathic effect, $N$ - $t$ amino-terminus, C-CoV-2 Convalescent SARS-CoV-2, NTD N-terminal domain ((residue 1-290), S2P ecto $S_{\text {ectodomain trimer (S }}$ ecto), C1 Class1, C2 Class 2, C3 Class 3, C4 Class 4, WO those without structure analysis

able to bind RBDs in the "up" and "down" conformations and therefore, belongs to Class 2 [136]. The epitope and approach of binding to the RBD used by COVA2-04 is similar to that by CR3022, and hence, is categorized to Class 4 [28-30, 136] (Table 2).

The mAbs COV2-2196 and COV2-2130, which bind near the hACE2-binding site, exhibit powerful neutralizing activities. These mAbs present, in pseudovirus neutralization assays, an $\mathrm{IC}_{50}$ of $0.07 \mathrm{ng} / \mathrm{mL}$ and $1.6 \mathrm{ng} / \mathrm{mL}$, respectively, although they are less sensitive for neutralization of the authentic virus $\left(\mathrm{IC}_{50}: 15 \mathrm{ng} / \mathrm{mL}\right.$ and $107 \mathrm{ng} /$ $\mathrm{mL}$, respectively). Both $\mathrm{mAbs}$ recognize the $\mathrm{RBD}$ in the "up" configuration, although they do not compete with the virus for binding with hACE2. Furthermore, COV22130 presents different competitive binding sites and is able to interact with an RBD in the "down" state, indicating that it could recognize the RBD in the "up" or "down" conformations by probably binding to three distinct sites on the S protein trimer [208]. Due to their differences in binding, COV2-2196 and COV2-2130 has been tested for prophylactic efficacy using a mouse-adapted SARSCoV-2 model [208]. A cocktail of COV2-2196 (16 ng/ $\mathrm{mL})$ and COV2-2130 $(63 \mathrm{ng} / \mathrm{mL})$ presents a synergistic effect on virus neutralization in vitro compared with the effect observed by using $250 \mathrm{ng} / \mathrm{mL}$ of the Abs individually [208].

The Abs C002, C119, C121, C135, and C144 obtained from peripheral blood mononuclear cell of patients with COVID-19, interact with the RBD using different binding modes and present a strong pseudovirus neutralization effect $\left(\mathrm{IC}_{50}: 9.0 \mathrm{ng} / \mathrm{mL}, 9.0 \mathrm{ng} / \mathrm{mL}, 6.7 \mathrm{ng} / \mathrm{mL}, 16.0 \mathrm{ng} /\right.$ $\mathrm{mL}$, and $6.9 \mathrm{ng} / \mathrm{mL}$, respectively). Moreover, the Abs $\mathrm{C} 121, \mathrm{C} 135$, and 144 also neutralize authentic SARSCoV-2 ( $\left(\mathrm{IC}_{50}: 1.6 \mathrm{ng} / \mathrm{mL}, 2.9 \mathrm{ng} / \mathrm{mL}\right.$, and $2.5 \mathrm{ng} / \mathrm{mL}$, respectively) [142]. C002, C119, and $\mathrm{C} 121$ bind both the "up"- and "down"-state RBDs, where the Fab-S structures 
suggest a quaternary epitope, including the neighboring RBDs, to also support bivalent interactions with two "down"-state RBDs. Additionally, C002 seems to be in contact with glycans in the RBD [142]. C135 and C144 bind the same "up" RBD conformation. In addition, C135 binds a "down"-state RBD regardless of the conformation of the neighboring RBDs. The conformational changes in the RBD allow the configuration of a quaternary epitope, which is formed by neighboring "down"-state RBDs that are recognized by $\mathrm{C} 144$ through its long CDRH3 loop. This unique interaction locks the $\mathrm{S}$ protein domains in a pre-fusion conformation, thereby avoiding the $\mathrm{S}$ proteinopen conformation, in which it engages with hACE2 $[142,194]$ (Table 2).

The humanized mAb H014 has been obtained from an Ab library constructed by phage display from immunized mice with recombinant RBD from SARS-CoV [4]. H014 neutralizes the SARS-CoV-2 pseudovirus infection $\left(\mathrm{IC}_{50}: 3 \mathrm{nM}\right)$ and authentic SARS-CoV-2 infection $\left(\mathrm{IC}_{50}: 38 \mathrm{nM}\right)$. Cryo-EM characterization of H014 Fab in complex with the SARS-CoV-2 S protein trimer suggests a novel conformational RBD epitope accessible in an "open" conformation, where the mAb interacts with the $S$ protein and blocks the hACE2 engagement by steric hindrance and the associated protein-protein interactions, different to the RBM interaction [4]. Interestingly, $\mathrm{H} 014$ is capable of neutralizing in vivo in a hACE2 mouse model with a prophylactic dose [4] (Table 2). This Ab is categorized in Class 4, together with CR3022, EY6A, S304, and S2A4 [4, 13, 27, 28, 178]. In general, Abs grouped in Class 4 need the highest concentration to reach the neutralization effect compared with Abs from the other classes.

\section{Mutants could reduce Abs neutralization}

RBD mutations have been related with the reduction of the sensitivity or confer resistance to neutralizing Abs. For instance, mutations N439K, L452R, A475V, V483A, E484K, G485D, F486A, F490L, and Y508H weaken the binding of mAbs, such as 157, 247, CB6, P2C-1F11, B3SCA1, X593, 261-262, H4, P2B-2F6, H014, and H00S022 [4, 19, 30, 135]. The V483A variant, with a mutation frequency greater than $0.1 \%$, elicits a loss of activity of mAbs, such as P2B-2F6 and X593 [19, 135]. While $\mathrm{V}_{\mathrm{H}}-\mathrm{Fc}$ ab8 loss neutralizing activity against F486A mutant [209]. As well as REGN10933 showed a reduction of the sensitivity against E484K and G485D [145]. Similarly, RBD variants such as Q414E, N439K, G446V, K458N, I472V, A475V, T478I, V483I, and F490L cause viral resistance to CP [19]. In addition, variants such as $\mathrm{N} 439 \mathrm{~K}$ and $\mathrm{Y} 508 \mathrm{H}$ are increasing in circulation [19]. Moreover, variants in the RBD or $S_{1}$ subunit, which allow the viral particle to increase its transmissibility, pathogenicity, infectivity, and resistance, will continue to occur. D614G is a frequent mutation that does not occur in the RBD [48]. Although it has been related to SARSCoV-2 infectivity and worsened COVID-19 symptoms, its participation in virus resistance has scarcely been demonstrated [48]. In contrast, Abs such as $2 \mathrm{H} 2,3 \mathrm{C} 1$, CC6, CC12, and CC25 neutralize the D614G variant [16, $48,210,211]$. As well as STE90-C11 recognized with elevated affinity RBD mutations like V367F, N439K, G476S, V483A, E484K, G485R, F486V [212]. These data indicate the importance of using different Abs to achieve therapeutic effectiveness.

\section{Cocktails of $A b s$}

Based on distinct epitopes conserved in the $S$ protein domain, a cocktail of neutralizing Abs has been used to mitigate the risk of COVID-19. Such cocktails can significantly enhance the neutralizing abilities $[48,143$, 213, 214]. For example, to complement the neutralizing effect of H014 it was combined with the non-competitive antibody P17 obtained from a library of naive human antibodies. P17 has high affinity for RBD, and a potent neutralizing activity with pseudovirus $\left(\mathrm{IC}_{50}: 0.165 \mathrm{nM}\right)$ and highest $\mathrm{IC}_{50}$ against the authentic virus than $\mathrm{H} 014$. According to the authors, the cocktail of P17 and H014 improves (two to ten-fold) the protective effect against SARS-CoV-2 in mouse model [213].

Other combinations such as B38+H4, REGN10933+REGN10987, AZD8895+AZD1061, 414$1+555-63+553-15, \quad$ COV2-2196+COV2-2130, and CR3022+CR3014 have been evaluated [26, 48, 214]. In fact, the addition of $553-15$ to $414-1+555-63$ or the combination of COV2-2196 with COV2-2130 has been shown to provide a synergistic neutralization effect [208, 214]. Furthermore, cocktails may have therapeutic potential in a possible SARS-CoV-2 reinfection, which has not been noted for other therapies [34, 215].

\section{Abs Fc-mediated effector functions}

The Fc-mediated effector functions, such as ADCC or $\mathrm{ADCP}$, can contribute to virus clearance independent of the $\mathrm{mAb}$ neutralization effect $[216,217]$. Briefly, infected cells may expose the Ags on the pathogen surface that can also be recognized by IgG, which through its Fc region binds the $\mathrm{F} c \gamma$ receptors $(\mathrm{F} c \gamma \mathrm{Rs})$ and can attract other cells. In addition, IgGs bind C1q, drifting away from the complement-dependent cytotoxicity (CDC) pathway, which involves the IgG-bound $\mathrm{Ag}$ and recognition of the $\mathrm{C} 1$ complex [218]. Cytotoxic Abs, such as alemtuzumab, dinutuximab, and ofatumumab, present their main mechanism of action through ADCC and CDC. In fact, the Fc region of an $\mathrm{Ab}$ determines its serum half-life and effector functions, which are associated with the $\mathrm{N}$-glycan structure 
$[219,220]$. In particular, the absence of the fucose residue at the core increases the ADCC [221, 222].

Pinto et al. [27] demonstrated that S309 mediates ADCC in SARS-CoV-2 S protein-transfected cells, along with the strongest ADCP response by monocytes, among the immune cells, via Fc $\gamma$ RIIIa and Fc $\gamma$ RIIa engagement and affinity for an FcyRIIIa variant (V158). It also activates the CDC pathway [178]. S306 activates ADCC and ADCP with intensity lesser than that of S309. S2M11 promotes FcyRIIIa-dependent ADCC in a dose-dependent manner and does not promote FcyRIIa-mediated ADCC, with a high affinity towards the V158 variant comparable to that of S309 [27]. Moreover, S2M11 also exerts ADCP. S2E12 triggers Fc $\gamma$ RIIa but not FcyRIIIa signaling, unlike S2M11 and S309. Furthermore, a combination of S2M11 with S2E12 or S309 activates effector functions [223]. S2H13 promotes ADCC through FcyRIIIa (V158) activation, but presents a weak activation of FcyRIIa. Additionally, S2H13 is effective in killing Chinese hamster ovary $(\mathrm{CHO})$ cells stably transfected with SARS-CoV-2 S protein via CDC. A superior ADCC response by REGN10987 compared with REGN1089, REGN10933, and REGN10934 has been observed, but all Abs have been shown to induce ADCP [145]. These findings highlight the differences in Abs and their relationship with FcyRIIIa and FcyRIIa receptors, or C1q, which can be decisive in displaying their protective mechanisms $[27,178,223]$.

\section{Hybridoma Abs}

The recent discovery of potent antibodies has been driven using different technologies [46] instead of the traditional hybridoma production, although some Abs were also obtained by this strategy. Hybridomas were introduced in 1975 by Köhler and Milstein [224], and these are cloned cell lines produced by the fusion of a B lymphocyte of interest and an immortalized myeloma cell, which are capable of secreting large quantities of pure Abs [225]. Although hybridoma development represents a laborintensive and time-consuming process [226], research related to hybridomas has continued over time. Accordingly, COVID-19 research has not excluded hybridomas, as there are multiple studies using this strategy for treating SARS-CoV-2 infection [12, 227-230]. In recent studies, Abs from hybridomas with the ability to crossneutralize SARS-CoV and SARS-CoV-2 in vitro have been identified [12, 227, 229], similar to those previously reported in terms of cross-neutralization amongst different CoVs (SARS-CoV, MERS-CoV, and SARS-CoV-2) [3, $29,135,231,232]$.

The mAb 47D11 obtained from SARS-S hybridoma supernatants has been humanized [12]. Importantly, $\mathrm{mAb}$ 47D11 does not interfere with the recognition and binding of the $S$ protein with hACE2, owing to a mechanism that remains unknown $[12,47]$. In addition, it has been demonstrated that its ability to perform a crossneutralization is possibly by interactions with the conserved central region of the $S$ protein from the RBD domain [12] (Additional file 1: Table S3). Another Ab obtained by the hybridoma technique is MAB362, whose variable sequences are expressed as IgG or monomeric IgA isotypes. IgA-type $\mathrm{Ab}$ presents higher neutralizing activity than its IgG homolog due to its "longer arms" and "greater flexibility" in the hinge domain, which allows the neutralization of $\mathrm{S}$ proteins from other CoVs. Additionally, IgA is proposed to have a greater persistence in mucosal secretions compared with the other isotypes [227]. Another mAb obtained from hybridoma

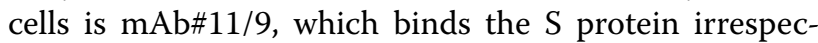
tive of its glycosylation pattern [228], being also recognized by Abs SiD7h and S3D8h $\left(\mathrm{IC}_{50}\right.$ of $113.3 \mathrm{ng} / \mathrm{mL}$ and $137.2 \mathrm{ng} / \mathrm{mL}$, respectively) [229]. Furthermore, six groups of mice hybridoma Abs with neutralizing capacity that recognized different epitopes on RBD has been described and can be employed as diagnostic tools in SARS-CoV-2 infection [230]. Using the same technique, the $\mathrm{Abs} 2 \mathrm{H} 2$ and $3 \mathrm{C} 1$ were developed, targeting different regions of $\mathrm{S}$. Both have the ability to neutralize infection by SARS-CoV-2 virus. In particular $2 \mathrm{H} 2$, potently neutralize SARS-CoV-2 pseudovirus $\left(\mathrm{IC}_{50}: 0.025 \mu \mathrm{g} / \mathrm{mL}\right)$ and authentic SARS-CoV-2 ( $\left.\mathrm{IC}_{50}: 0.007 \mu \mathrm{g} / \mathrm{mL}\right)$. Interestingly, the human-mouse chimeric Abs $\mathrm{c} 2 \mathrm{H} 2$ and the $\mathrm{c} 2 \mathrm{H} 2 /$ c3C1 cocktail (with the same $\mathrm{IC}_{50}$ of $0.054 \mu \mathrm{g} / \mathrm{mL}$ ) could significantly reduce viral loads in $\mathrm{Balb} / \mathrm{c}$ mice, showing therapeutic efficacy [210].

\section{Neutralization of SARS-CoV-2 by nanobodies}

In mammals, Abs present two chains (heavy and light), whereas in camelids, Abs containing homodimeric heavy chain with no $\mathrm{C}_{\mathrm{H}} 1$ but a conserved Ag-binding domain $\left(\mathrm{V}_{\mathrm{H}} \mathrm{H}\right)$ can be found (Fig. 2e). The $\mathrm{V}_{\mathrm{H}} \mathrm{H}$ is also known as a single-domain $\mathrm{Ab}$ (sdAb) or nanobody (Nb) (Fig. 2d, f), which can be selected from synthetic, naive, or immunized cDNA libraries using phage, bacterial, yeast, or ribosomal display technologies [233-235]. Nbs have the smallest structures $(\sim 13 \mathrm{kDa})$ compared with other Abs, present with antigenic recognition, can act in a monomeric form or fusion protein, and show high specificity, stability, and solubility [236]. Therefore, Nbs are valuable in biomedical research. The first therapeutically active $\mathrm{Nb}$ caplacizumab-yhdp designed for treating thrombotic thrombocytopenic purpura and thrombosis (Ablynx, a Sanofi Company, Ghent, Belgium) was approved by the European Medicines Agency (EMA) in 2018 and the U.S. Food and Drug Administration (FDA) in 2019 [237]. Accordingly, Nbs with high affinity against SARS-CoV-2 
$S$ proteins, and the RBD could emerge as potential therapeutics in the fight against COVID-19, in line with the repertoire of potent neutralizing Nbs previously reported (Additional file 1: Table S5).

\section{Camelid immune libraries}

Distinct $\mathrm{Nbs}$ have been developed against SARS-CoV and MERS-CoV, such as $\mathrm{V}_{\mathrm{H}} \mathrm{H}-55$ and $\mathrm{V}_{\mathrm{H}} \mathrm{H}-72$ [238]. $\mathrm{V}_{\mathrm{H}} \mathrm{H}-72$ when converted into a bivalent Fc (human IgG1) fusion form neutralizes the $\mathrm{S}$ protein of SARS-CoV-2 pseudovirus $\left(\mathrm{IC}_{50}\right.$ of $\sim 0.2 \mu \mathrm{g} / \mathrm{mL}$ ). Pretreatment with $\mathrm{V}_{\mathrm{H}} \mathrm{H}-72-\mathrm{Fc}$ has been observed to reduce the viral load in the lungs of Syrian hamsters by $\sim 10^{5}$-fold compared with that in the untreated control animals [239] (Additional file 1: Table S5). According to the differing neutralization effects noted for $\mathrm{V}_{\mathrm{H}} \mathrm{H}-72$ and $\mathrm{V}_{\mathrm{H}} \mathrm{H}-72-\mathrm{Fc}$, there exists different epitopes between them, and the crystal structures indicate that $\mathrm{V}_{\mathrm{H}} \mathrm{H}-72$-Fc interacts with the RBD as a Class $4 \mathrm{Ab}$ [240]. ExeVir Company (Ghent, Belgium) has advanced with the development of $\mathrm{V}_{\mathrm{H}} \mathrm{H}-72-\mathrm{Fc}$ through preclinical and clinical trials. The NIH-CoVnb-112 Nb has been obtained from a llama immunized with the SARS-CoV-2 S protein, and it blocks the SARS-CoV-2 RBD and hACE2 engagement [240]. W25UACh obtained from a $\mathrm{V}_{\mathrm{H}} \mathrm{H}$ library using $E$. coli display, is able to recognize beads coated with the S protein [241]. Ty1 binds the RBD with a high affinity and present neutralization activity against SARS-CoV-2 pseudovirus $\left(\mathrm{IC}_{50}: 77 \mathrm{ng} /\right.$ $\mathrm{mL}$ ), avoiding hACE2 interaction; cryo-EM reconstruction revealed this complex with the RBD in both the "up" and "down" conformations as belonging to Class 2 having Abs with a quaternary epitope [242] (Additional file 1: Table S5). Ty1 multimeric constructs as the tetramer 4-arm PEG Ty1 increased its neutralizing capacity dramatically $\left(\mathrm{IC}_{50}: 13 \mathrm{pM}\right)$ [243].

In contrast, Nbs such as Nb-Set1, NM1226, NM1228, NM1230, and NM1224, also derived from an immunized camelid, present high neutralization potencies against authentic SARS-CoV-2 $\left(\mathrm{IC}_{50}: \sim 15 \mathrm{nM}, \sim 7 \mathrm{nM}, \sim 37 \mathrm{nM}\right.$, and $\sim 256 \mathrm{nM}$, respectively). Furthermore, these Nbs block the RBD-hACE2 interaction and target different epitopes within the RBD [244]. Moreover, the Nbs 89, 20 , and 21 obtained from the RBD-immunized camelid serum present high neutralization activities against authentic SARS-CoV-2 $\left(\mathrm{IC}_{50}: 20.154 \mathrm{nM}, 0.048 \mathrm{nM}\right.$, and 0.22, respectively) [237] (Additional file 1: Table S5). By modeling the Nbs 20 and 21, it has been revealed that they probably interact with the RBD in the "down" conformation [245]. On the other hand, Nb11-59, was obtained from camels immunized with the recombinant RBD of SARS-CoV-2, and present neutralizing activity against the authentic SARS-CoV-2 with neutralizing dose $50\left(\mathrm{ND}_{50}\right)$ of $0.55 \mu \mathrm{g} / \mathrm{mL}$, and inhibit the replication of eight RBD SARS-CoV-2 mutants (Q321L, V341I, N354D, V367F, K378R, V483A, Y508H, H519P) [246].

\section{Camelid naïve libraries}

$\mathrm{H} 11$ has been identified in a naïve llama $\mathrm{V}_{\mathrm{H}} \mathrm{H}$ library using phage display and found to target the RBD. Later, using random mutagenesis, Nbs H11-D4 and H11-H4 have been generated. Both $\mathrm{Nbs}$ are able to block the attachment of the S protein to hACE2 in vitro, recognizing different epitopes compared with CR3022 [30]. H11D4-Fc and H11-H4-Fc fusions show neutralizing activity against authentic SARS-CoV-2 $\left(\mathrm{ND}_{50}: 18 \mathrm{nM}\right.$ and $6 \mathrm{nM}$, respectively) [30]. Cryo-EM reveals that both Nbs bind RBDs in the "up" and "down" conformations in the S protein trimer and hence, these are categorized as Class 2 Abs [30].

Three synthetic $\mathrm{V}_{\mathrm{H}} \mathrm{H}$ camelid libraries using ribosome and phage displays have allowed the generation of synthetic Nbs, termed as "sybodies" (Sbs) [247]. Sixty-three anti-RBD Sbs have been obtained from three libraries, screened by one round of ribosome display and two rounds of phage display against the RBD [248]. Other Sbs have been isolated from libraries such as SR4, MR17, MR3, and MR4, presenting high neutralization potencies against SARS-CoV-2 pseudovirus $\left(\mathrm{IC}_{50}: 5.9,12.32\right.$, 0.40 , and $0.74 \mu \mathrm{g} / \mathrm{mL}$, respectively). Crystal structures of the complexes of Sbs and the RBD reveal a common neutralizing mechanism, suggesting that SR4, MR17, and probably MR3 interfere with the interaction between the RBD and hACE2 [249]. Divalent-engineered Sbs used to synthetize the MR3-MR3-albumin binding domain have been demonstrated to be the best for improving neutralization activities against pseudotyped virus $\left(\mathrm{IC}_{50}: 0.012 \mu \mathrm{g} / \mathrm{mL}\right)$. These Sbs have also been evaluated in SARS-CoV-2-infected C57BL/6J female mice, and the lung viral titers were found to be 50 -fold lower than that in the control mice [249]. In the Sb-treated group, the alveolar wall structures were normal, although mild bronchopneumonia was observed; whereas, the lung viral load was reduced [249]. Sb23 has been isolated from a synthetic library, and interferes with the RBD and hACE2 interaction showing neutralizing activity against SARSCoV-2-S pseudotyped virus $\left(\mathrm{IC}_{50}: 0.6 \mu \mathrm{g} / \mathrm{mL}\right)$ [250]. The cryo-EM structure suggested $\mathrm{Sb} 23$ as a Class 2 indicating that interacts with the $\mathrm{S}$ protein, wherein two RBDs are in the "up" conformation [250]. SR31, another Sb isolated from a synthetic library, interacts with the RBD, distorting it, and does not neutralize SARS-CoV-2 pseudovirus [251]. Since SR31 displays high affinity, its fusion with other neutralizing Sbs, such as SR31-MR17 or SR31MR6, increases the neutralization activity against SARS$\mathrm{CoV}-2$ pseudovirus $\left(\mathrm{IC}_{50}: 52.8 \mu \mathrm{g} / \mathrm{mL}\right.$ or $2.7 \mu \mathrm{g} / \mathrm{mL}$, respectively) [251]. 
The synthetic Nbs Nb3, Nb6, and Nb11 have been obtained through screening of a yeast surface-displayed library using multiple S protein epitopes [252]. Particularly, Nb6 has a potent neutralization activity against pseudovirus infection $\left(\mathrm{IC}_{50}: 2.0 \mu \mathrm{M}\right)$. Cryo-EM revealed that Nb6 binds to the RBD in the open and closed $\mathrm{S}$ conformations, and belongs to Class 2 according to the Barnes classification [194]. Furthermore, the trivalent version of Nb6 (Nb6-tri) has shown an improvement in the neutralization activity against the authentic SARSCoV-2 ( $\left.\mathrm{IC}_{50}: 140 \mathrm{pM}\right)$ [252]. In addition, multi-specific $\mathrm{V}_{\mathrm{H}} \mathrm{H}$ Abs fused to human IgG1 Fc domains are able to activate the Fc-dependent functions, such as tri-specific $\mathrm{V}_{\mathrm{H}} \mathrm{H}-\mathrm{Fc}$ 3F-1B-2A, which has been designed to neutralize SARS-CoV-2 [253]. The tri-specific $\mathrm{V}_{\mathrm{H}} \mathrm{H}-\mathrm{Fc} 3 \mathrm{~F}-1 \mathrm{~B}-2 \mathrm{~A}$ $\mathrm{Ab}$, which in a docking model has been observed to interact with the RBD, exhibits higher pseudovirus neutralization activity than that by other $\mathrm{V}_{\mathrm{H}} \mathrm{H}$-Fc combinations $\left(\mathrm{IC}_{50}: 3.0 \mathrm{nM}\right.$ ) [253] (Additional file 1: Table S5). Other Nbs have been obtained from camelid $\mathrm{V}_{\mathrm{H}} \mathrm{H}$ naïve and synthetic libraries. Nbs were fused with IgG1 Fc domains to obtain two monoclonal $\mathrm{V}_{\mathrm{H}} \mathrm{H}-\mathrm{Fc}$ named as $1 \mathrm{~B}$ and $3 \mathrm{~F}$ and one bi-specific 1B-3F-Fc, which block the binding of hACE2 with S, being 1B-3F-Fc the best in blocking function [254]. In the same sense, the $\mathrm{Nb}$ nanosota- $1 \mathrm{C}$ was obtained from naïve camelid $\mathrm{Nb}$ phage display library, which presents high RBD affinity. The same Nb in Fc format (Nanosota-1C-Fc) increases the RBD affinity and presents strong neutralizing effect against SARS-CoV-2 pseudovirus $\left(\mathrm{ND}_{50}: 270 \mathrm{ng} / \mathrm{mL}\right)$ and against authentic virus $\left(\mathrm{ND}_{50}: 160 \mathrm{ng} / \mathrm{mL}\right)$. Interestingly, it protected prophylactically, and therapeutically Syrian hamsters infected with SARS-CoV-2 [255].

\section{Human Nbs against SARS-CoV-2}

Humanization of camelid Nbs has been aimed to reduce their immunogenicity. Nbs against the SARS-CoV-2 RBD have been detected in a library of phage-displayed sdAbs that uses naïve CDR regions together with human germline frameworks, with varied arrangements [256]. Among them, n3088 and n3130 inhibit SARS-CoV-2 pseudovirus infection $\left(\mathrm{IC}_{50}: 3.3\right.$ and $3.7 \mu \mathrm{g} / \mathrm{mL}$, respectively), and neutralize the authentic SARS-CoV-2 $\left(\mathrm{IC}_{50}\right.$ : 2.6 and $4.0 \mu \mathrm{g} / \mathrm{mL}$ respectively) [256]. Both $\mathrm{n} 3088$ and n3130 share some residues with the cryptic epitope recognized by CR3022, as suggested by binding models [28, 256]. Another study identified $V_{H}$ ab8 fused with human IgG1 Fc $\left(\mathrm{V}_{\mathrm{H}}-\mathrm{Fc}\right.$ ab8), and this bivalent form shows a potent neutralization activity against pseudotyped SARSCoV-2 ( $\left.\mathrm{IC}_{50}: 0.03 \mu \mathrm{g} / \mathrm{mL}\right)$, as well as the authentic SARS$\mathrm{CoV}-2\left(\mathrm{IC}_{50}: 0.04 \mu \mathrm{g} / \mathrm{mL}\right) . \mathrm{V}_{\mathrm{H}}-\mathrm{Fc}$ ab8 is categorized as Class $2 \mathrm{Ab}$, and it competitively inhibits the hACE2-RBD interaction by occupying three RBDs (two in the "down" and one in the "up" conformation) [209]. Furthermore, $\mathrm{V}_{\mathrm{H}}$-Fc ab8 binds several RBD mutants found in patients with COVID-19, and its prophylactic and therapeutic efficacy has been demonstrated against SARS-CoV-2 infection in hamsters [209].

Other synthetic humanized sdAbs (1E2, 2F2, 3F11, $4 \mathrm{D} 8$, and $5 \mathrm{~F} 8$ ) in a bivalent form fused with human IgG1 Fc have been shown to inhibit the association between the RBD and hACE2, presenting superior neutralization potencies against pseudotyped SARS-CoV-2-S $\left(\mathrm{EC}_{50}\right.$ : $0.54,0.40,0.01,0.46$, and $0.05 \mu \mathrm{g} / \mathrm{mL}$, respectively) (Additional file 1: Table S5) [257]. Moreover, from a library of engineered human $\mathrm{V}_{\mathrm{H}} \mathrm{s}, \mathrm{V}_{\mathrm{H}}$ ab6 and $\mathrm{V}_{\mathrm{H}} \mathrm{m} 397$ have been obtained, which compete with the RBD for hACE2 binding. Both $\mathrm{V}_{\mathrm{H}}$ s fused with Fc (VH-Fc ab6 and VH-Fc m397) have been shown to neutralize the authentic SARS-CoV-2 $\left(\mathrm{IC}_{50}: 0.35 \mu \mathrm{g} / \mathrm{mL}\right.$ and $1.5 \mu \mathrm{g} /$ $\mathrm{mL}$, respectively) and present differences in competition probably due to different target S protein epitopes [258]. Biparatopic and trivalent Nbs against RBD were obtained from human $\mathrm{VH}$-phage library. $\mathrm{VH}$ monomers were used to design bi-paratopic or multivalent $\mathrm{VHs}$, with the aim to recognized different RBD epitopes simultaneously [179]. New formats improved the viral neutralization, being the most potent the trivalent $\mathrm{VH} 3 \mathrm{~B} 01$ against over authentic SARS-CoV-2 $\left(\mathrm{IC}_{50}: 3.98 \mathrm{nM}\right)$, which seems to block simultaneously the hACE2 and RBD interaction through the attack of three RBDs [179].

The diversity of Nbs found and the variety of neutralization mechanisms indicate their promising application in the therapy or prophylaxis of SARS-CoV-2 infection.

\section{Remarks on the production of mAbs for COVID-19 treatment}

Antibodies obtention from patients with COVID-19 is a fruitful strategy to recover human specialized neutralizing Abs. However, few discussions have been conducted on $\mathrm{mAb}$ production technologies in order to obtain quality $\mathrm{mAbs}$ that are safe, efficient, and accessible to the population [259]. The tetrameric nature of an IgG molecule and its glycosylation is essential for its functioning, making it a challenging protein for expression [260]. In this sense, mammalian cells, such as $\mathrm{CHO}$ cells, have become one of the most widely used cell factories for the industrial production of mAbs $[261,262]$ and are considered the workhorse of the industry [263-265]. Among the 68 mAbs approved between 2014 and 2018, 84\% were produced in $\mathrm{CHO}$ cells and $16 \%$ in cells derived from myelomas (13\% in NS0 and 3\% in Sp2/0) [262]. Even during the pandemic in 2020, $10 \mathrm{Ab}$ therapeutics had been approved by EMA or FDA [259]. Furthermore, over 60 previously known Abs are under evaluation for possible COVID-19 treatments [259]. Compared with bacteria and yeasts, the 
yields and productivities of processes based on mammalian cells are low due to the slow rate of cell growth, their tendency to undergo apoptosis, and a low production capacity per cell $[260,261]$. Therefore, developing cells with superior production characteristics has been aimed in the field [264, 266-268]. Nevertheless, owing to cell engineering, the time for the establishment of productive cell lines of fully humanized mAbs has sharply reduced, limiting it to some months, with increased productivities (up to $100 \mathrm{pg} /$ cell day, representing bioreactor titers of nearly $10 \mathrm{~g} / \mathrm{L}$ ), which is presently crucial for the production of anti-SARS-CoV-2 mAbs [264, 269-271]. Elevated productive-mAb titres have also been achieved by extensive improvements in the production schemes [272]. Similarly, improvements in the recovery and purification of mAbs have achieved yields of up to $80 \%$ of that produced in bioreactors, and consequently, the manufacturing costs of goods have dropped to 20-100 US\$ per gram of the active pharmaceutical ingredient [270, 273].

Evidently, with the search for tools to attend the COVID-19 pandemic, and since the start-up of production of mAbs at industrial scale can take at least 6 months, Nbs production became an alternative. Due to the fact that $\mathrm{Nbs}$ are smaller and not glycosylated proteins they can be produced in cell factories such as bacteria or yeasts, at lower costs, with a larger scale of production [274]. Moreover, monomeric or multimeric $\mathrm{V}_{\mathrm{H}} \mathrm{Hs}$ can be produced without implying major changes in the bioprocess unit operations. However, as they are new molecules with complex and novel structural characteristics, the quality, safety and efficacy tests must be highly rigorous, and the regulatory approval could be longer and intensive than a complete $\mathrm{mAb}[274,275]$. The humanized Nb11-59 (Additional file 1: Table S4) was expressed in Pichia pastoris in small-scale and in $7 \mathrm{~L}$ bioreactor, reaching almost $20 \mathrm{~g} / \mathrm{L}$ of the $\mathrm{Nb}$. HuNb11-59 was also purified by affinity chromatography and hydrophobic chromatography reaching around 95\% purity [246].

\section{CHO cells as producers of anti-SARS-CoV- 2 mAbs}

$\mathrm{CHO}$ cells were established and considered "immortal" by the end of the 1950s [264]. CHO cells present several advantages over other cell types for the production of mAbs: (i) a capacity to perform complex post-translational modifications (PTMs), such as "human"-like glycosylations, protein processing (e.g., phosphorylation) and folding, (ii) robust cell culture in chemically-defined and serum-free media that facilitates scaling-up, (iii) a safe host with a high rate of regulatory approval, and (iv) optimized transfection/selection systems that enable stable expression of heterologous genes [261, 263-265, 276].
Efforts have been made to optimize recombinant protein production in $\mathrm{CHO}$ cells, reduce manufacturing costs, and increase accessibility of life-changing drugs to patients $[264,266]$. In this sense, mAb production involves a series of processes dictated by transcription (strength of the promoter, integration site for the gene of interest, and mRNA turnover), but also by the translation rate, protein turnover, and protein folding and processing [266]. Limited studies indicate the expression of recombinant anti-SARS-CoV-2 mAbs in $\mathrm{CHO}$ cell lines [145] some using transient expression [17, 178, 184, 277] with low utility at an industrial scale. Moreover, there are some studies on the production of the His-tagged SARSCoV-2 S protein trimer or the S protein by CHO cells [27, 278]. Furthermore, to date there are at least 21 clinical studies evaluating anti-SARS-CoV-2 mAbs (Additional file 1: Table S4); however, information of large-scale production of mAbs has not been reported [52, 53, 279].

\section{Challenges in the production of anti-SARS-CoV-2 mAbs}

Although there are more than $70 \mathrm{mAbs}$ licensed, only few of them have been approved or are under review in the EU or USA to treat or prevent diseases caused by viruses, such as human immunodeficiency virus infection, lower respiratory tract disease caused by syncytial virus in children, Ebola, and recently, COVID-19 [52, 53, 259]. Moreover, there are just one therapeutically active $\mathrm{Nb}$ approved in USA and EU [237]. Some of the mAb products are a combination of two or three mAbs. Accordingly, therapeutic Abs against SARS-CoV-2 should be combined cocktails that they recognize different epitopes in $\mathrm{S}$ including varied Abs formats and classes [52, 53, $144,280]$. Hence, the current challenges in large-scale production of Abs necessary to fight the pandemic are related to achieving production of all formats of Abs in cell factories with elevated productivities, as well as the scaling-up bioprocesses to generate enough amounts of the active pharmaceutical ingredient (API) to cover the world population.

Moreover, the location and optimum operation of production plants with stringent quality control practices worldwide, including Africa and Latin America, needs to be determined, along with the recruitment of skilled labor. Furthermore, multiproduct facilities should be considered to produce $\mathrm{Ab}$ cocktails. In addition to the quality assurance, it is necessary to demonstrate batchby-batch reproducibility in bioprocesses. The production of anti-SARS-CoV-2 mAbs in $\mathrm{CHO}$ cells can be seen as a feasible strategy for implementation on an industrial scale in conjunction with high-density cultures [272], single-use technologies [267], design/selection techniques for highly productive clones [264, 281], and bioprocess optimization [266]. To achieve this, it is necessary that 


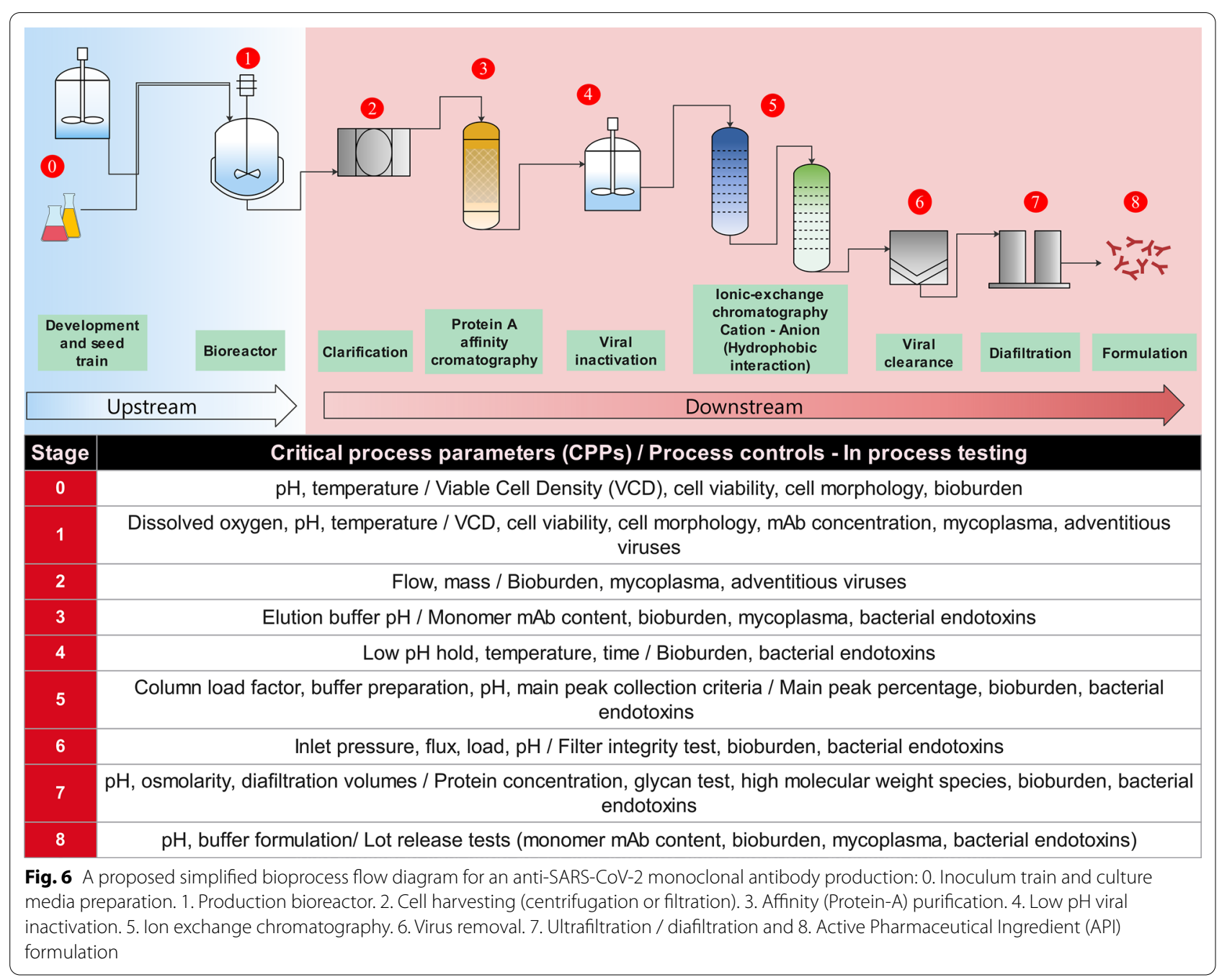

companies with large biotechnological developments provide insights to the bio-pharmacological industry to combat this global pandemic.

\section{Upstream and downstream bioprocesses in mAb production}

The upstream production of mAbs in $\mathrm{CHO}$ cells is widely conducted using suspension cultures in stirred tank bioreactors under different modes: batch, fed-batch, and perfusion (continuous culture with retention of cells), although in the process of increasing the cell number (inoculum train) to reach the production volume, other types of bioreactors are also used, such as shake flasks and wave bioreactors, with preference for single-use systems $[267,282]$. While, the production Nbs bioprocesses can be carried out in bacterial or yeasts conventional biopharmaceutical plants, where the inoculum train and the production bioreactors are generally made of stainless steel, with economical culture media, implying larger industrial scales than those of animal cells. In general, upstream process development also includes scaling-up the culture process for reproduction on a large scale. An in-depth understanding of the process and its critical process parameters (CPPs) is essential to achieve a successful scale-up. The scale-up strategy involves keeping one or two parameters constant (scale-up criterion) across the different production scales [283]. In the case of mammalian cells, the aim is usually to keep the shear forces or oxygen transfer constant [283]. Moreover, technological, analytical, and regulatory advances promote biopharmacies to implement continuous culture systems to meet the growing demand for mAb production $[275,282$, 284]. $\mathrm{mAb}$ isolation and purification (downstream) represent a significant portion of the production effort and costs $[270,285]$. Hence, improvements in these aspects are relevant [285]. Furthermore, the downstream mAb manufacturing processes do not have a standard framework (Fig. 6); all processes rely on biomass clarification 
(biomass removal) and protein-A chromatography as the initial capture steps (providing in some cases $>98 \%$ purity in a single purification step). Subsequently, low-pH viral particle inactivation, viral particle removal, and polishing chromatographic steps are used to obtain the API [270]. The Nbs downstream can follow the procedures typically used for human therapeutic recombinant proteins (such as hormones, cytokines or stimulatory factors) produced in bacteria and yeast $[246,286]$.

The production level and the quality of Abs are highly sensitive to the operating conditions of the production process [287]. Ab production implies identification of the critical stages and variables in the process (Fig. 6), as well as determination of the critical quality attributes (CQAs) of the $\mathrm{Ab}$ to ensure its quality, safety, and efficacy (Additional file 1: Table S6). Then, CQAs are physical, chemical, biological, or microbiological properties with defined statistical limits, ranges, or distributions [287] (Additional file 1: Table S6). Given the relevance of the CQAs, the concept of quality by design $(\mathrm{QbD})$ emerges as an experimental strategy that requires a deep understanding of the bioprocess to determine the CPPs and the in-process testing parameters of the unit operations (Fig. 6) [287]. The implementation of process analytical technologies (PAT) is the most helpful strategy to ensure the quality, safety, and efficacy of mAbs [282]. CQAs should be carefully controlled and measured during both, upstream and downstream bioprocesses (Additional file 1: Table S6). Finally, the CQAs for an Ab finished pharmaceutical product must be taken into account, such as the $\mathrm{pH}$, protein amount, formulation, freezing/thawing, dose, color, lyophilization, drug delivery, and logistics, all of which, depend on the final product presentation.

\section{Conclusions and perspectives}

mAbs have revolutionized the treatment of different diseases, including viral diseases. Their applications in human therapy have improved with the development of completely human mAbs, thereby ensuring their quality, efficacy, and safety with reduced immunogenicity. However, the cost of Abs has always been a limiting factor in their use in the clinical settings, as well as their largescale distribution. This limitation has been overcome by improving the production processes, as well as the purification strategies.

Until now, different studies have shown that the immune response in many COVID-19 patients leads to the production of $\mathrm{CP}$, which contains specialized neutralizing Abs that can protect the patient against SARS$\mathrm{CoV}-2$, in conjunction with a series of other favorable immune responses. The recovery of the genetic and protein information on the Abs produced in COVID-19 patients and other immunized animals has allowed the identification of hundreds of Abs with neutralizing activity. Furthermore, these discoveries have led to the expression and production of Abs in different formats (mAbs, Fabs, Nbs, and sdAbs) to be characterized physically, chemically, and structurally. Some of these Abs are being tested in animal models, undergoing clinical trials, or recently mAbs approved for emergency use in humans. A cascade of information has been generated in this regard, which will surely lead to the generation of therapeutic and prophylactic solutions for the treatment of COVID19 , an unprecedented disease that remains uncontrolled globally. Thus, the search for neutralizing Abs that can serve in the control and therapy of SARS-CoV-2 infection needs to be exhaustive and remains urgent.

In COVID-19 patients, neutralizing Ab titers are correlated with the severity of the infection $[12,128,178]$ and low somatic hypermutation [137, 138, 142, 180]. The RBD region is found to be immunodominant and the target of approximately $90 \%$ of the neutralizing Abs present in the sera of SARS-CoV-2-infected people. Furthermore, it has been determined that the anti-RBD IgG titers decrease with time post symptom onset, presenting a half-life of approximately 49 days. Importantly, avidity increases over time, probably due to increased maturation. In the serum of hospitalized COVID-19 patients, there is a greater number of IgG against the protein $\mathrm{S}$ and the RBD, compared with that in non-serious and asymptomatic patients [178]. Therefore, all patients present anti-RBD IgGs, from patients with severe (most of them older than 50 years), high, medium, low, or atypical symptoms to asymptomatic patients (diverse age group with most of them between 20 and 60 years of age). The pediatric antibody production is different, since they produce anti-S but not anti- $\mathrm{N}$ Abs and present untrained $T$-cell responses together with a strong immune response acquired at birth that allows faster virus elimination [192, $288,289]$. In contrast, hospitalized adult patients present a high titer of Abs that block the interaction between the RBD and hACE2 [178]. Therefore, CP therapy using plasma from adult patients could increase the Ab content, and accordingly, it has been used as treatment in different clinical trials [147, 152, 153]. However, many concerns around the safety and efficacy of $\mathrm{CP}$ against COVID-19 exist. Consequently, the possibility of identifying neutralizing Abs and their characterization will avoid application of the whole CP.

Hence, in-depth analyses, isolation, characterization, and production of neutralizing Abs found in COVID-19 patients would allow for rational proposals of immunological protection [178]. Moreover, generation of polyvalent antivirals with at least four targets, as described by the four different Ab classes, using mAbs, Fabs, multabodies, Nbs, Sbs, or fusion proteins that interact with 
the RBD in the "up" and "down" conformations could broaden the spectrum of their therapeutic potential and prevent viral escape through mutations. In addition, combination of Abs, targeting different RBD epitopes or the new variants integrated in cocktails $[145,215$, 290], can ensure successful COVID-19 therapy. Of note, although recombinant $\mathrm{mAbs}$ have generally been used in human therapies for more than 20 years and are generally well tolerated, adverse effects (skin reactions, pyrexia, anaphylaxis even a systemic inflammatory response and ADE reaction, among others) must be well studied and characterized [48, 50,101, 102, 291]. Thus, passive immunization treatment could be one strategy to treat severe cases, people who do not respond to vaccination or cannot be vaccinated. Therefore, the vast amount of information generated will allow for the development of safe and effective treatments and vaccines for COVID-19, providing the molecular basis for the neutralization of pathogenic CoVs by Abs.

\begin{abstract}
Abbreviations
Ab: Antibody; ADCC: Antibody-dependent cell cytotoxicity; ADCP: Antibodydependent cellular phagocytosis; ADE: Antibody-dependent enhancement; Ag: Antigen; ARDS: Acute respiratory distress syndrome; CDC: Complementdependent cytotoxicity; CDR: Complementarity-determining region; $\mathrm{CHO}$ : Chinese Hamster Ovary cells; CP: Convalescent plasma; cryo-EM: Cryogenic electron microscopy; $\mathrm{EC}_{50}$ : Half-maximal effective concentration; $\mathrm{ND}_{50}$ : Neutralizing dose 50; Fab: Fragment antigen-binding; GM-CSF: Granulocyte-macrophage colony-stimulating factor; hACE2: Human angiotensin-converting enzyme; $\mathrm{I}_{50}$ : Half maximal inhibitory concentration; IGHV: Immunoglobulin heavy chain variable region; mAb: Monoclonal antibody; MASP-2: Mannanbinding lectin-associated serine protease 2; MERS-CoV: Middle East respiratory syndrome coronavirus; Nbs: Nanobodies; NK: Natural killer; NKG2A: Natural Killer Group Protein 2; NTD: N-terminal domain; PAMPs: Pathogen-associated molecular patterns; PDB: Protein data bank; PMTs: Post-translational modifications; PSO: Days-post symptoms onset; RBD: Receptor binding domain; RBM: Receptor-binding motif; RT-PCR: Reverse transcription polymerase chain reaction; SARS-CoV-2: Severe acute respiratory syndrome coronavirus 2; Sb: Sybody; sdAb: Single domain antibody; TLR: Toll-like receptor; VDJ: Variable $(V)$, diversity (D), and joining (J) genes segments; V-NAR: Variable domain new antigen receptor; $\mathrm{V}_{H} \mathrm{H}$ : Variable domain heavy chain.
\end{abstract}

\section{Supplementary Information}

The online version contains supplementary material available at https://doi. org/10.1186/s12934-021-01576-5.

Additional file 1: Table S1. Participation of the immune system in the infection by SARS-CoV-2. Table S2. Summary of outcomes regarding the use of convalescent plasma from COVID-19 patients. Table S3. Binding affinity of monoclonal antibodies that block or neutralize interaction between SARS-COV-2 and hACE2. Table S4. Clinical evaluation of mAbs against SARS-CoV-2. Table S5. Binding affinity of nanobodies that block or neutralize interaction between SARS-CoV-2 and hACE2. Table S6. Process and product related potential critical quality attributes (PCQAs) to be taken into account for the production of anti-SARS-CoV-2 mAbs to obtain a pure active pharmaceutical ingredient.

\section{Acknowledgements}

Bando-Campos C.G. (fellowship 366135), Ortega-Portilla P.A. (fellowship 707238), Cofas-Vargas L.F. (fellowship 508395), and Zelada-Cordero P. (fellowship 749447) are doctoral students from Programa de Doctorado en Ciencias Bioquímicas, Universidad Nacional Autónoma de México (UNAM). González-Hernández R.A. (fellowship 717832), Juárez-López D. (fellowship 388590), and Restrepo-Pineda S. (fellowship 589949) are doctoral students from Programa de Doctorado en Ciencias Biológicas, UNAM. HernándezPeralta P. (fellowship 394569) is a student from Doctorado en Ciencias de la Producción y de la Salud Animal, UNAM. All received fellowships from "Consejo Nacional de Ciencia y Tecnología" CONACYT. Coronado-Aceves E.W. thanks "Dirección General de Asuntos del Personal Académico (UNAM)" for the post-doctoral fellowship.

\section{Authors' contributions}

Conceptualization: MATR, NAVC. Funding acquisition: LC, CE, EGH, MATR, NAVC. Project administration: MATR, NAVC. Supervision: MATR, NAVC. Writing —original draft: All authors contributed equally. Writing — review \& editing: All authors contributed equally. All authors read and approved the final manuscript.

\section{Funding}

This work was supported by "Programa de Apoyo a Proyectos de Investigación e Innovación Tecnológica, Universidad Nacional Autónoma de México" (PAPIITUNAM IV-201220, Identification of antibody sequences from recovered and asymptomatic Mexican COVID-19 patients, and development of recombinant monoclonal antibodies as a possible treatment-Identificación de secuencias de anticuerpos de pacientes COVID-19 mexicanos recuperados y asintomáticos, y desarrollo de anticuerpos monoclonales recombinantes: posible tratamiento -). Funding sources had no role in study design, data collection and analysis, decision to publish, or preparation of the manuscript. This work was supported by project 1200962 FONDECYT (Chile) to CA.

\section{Availability of data and materials}

Not applicable.

\section{Declarations}

Ethics approval and consent to participate

Not applicable.

Consent for publication

Not applicable.

Competing interests

Authors declare that they have no conflict of interest.

\section{Author details}

${ }^{1}$ Programa de Investigación de Producción de Biomoléculas, Departamento de Biología Molecular y Biotecnología, Instituto de Investigaciones Biomédicas, Universidad Nacional Autónoma de México, Ciudad Universitaria, 04510 Ciudad de México, México. ${ }^{2}$ Instituto de Química, Universidad Nacional Autónoma de México, Ciudad Universitaria, 04510 Ciudad de México, México. ${ }^{3}$ Departamento de Inmunología, Instituto de Investigaciones Biomédicas, Universidad Nacional Autónoma de México, Ciudad Universitaria, 04510 Ciudad de México, México. ${ }^{4}$ Facultad de Medicina Veterinaria Y Zootecnia, Universidad Nacional Autónoma de México, Ciudad Universitaria, 04510 Ciudad de México, México. ${ }^{5}$ Escuela de Ingeniería Bioquímica, Pontificia Universidad Católica de Valparaíso, Av. Brasil № 2950, Valparaíso, Chile.

Received: 27 January 2021 Accepted: 3 April 2021

Published online: 22 April 2021

\section{References}

1. Dong E, Du H, Gardner L. An interactive web-based dashboard to track COVID-19 in real time. Lancet Infect Dis. 2020;20(5):533-4.

2. Petersen E, Koopmans M, Go U, Hamer DH, Petrosillo N, Castelli N, et al. Comparing SARS-CoV-2 with SARS-CoV and influenza pandemics. Lancet Infect Dis. 2020;20(9):e238-44. 
3. Zhu Z, Chakraborti S, He Y, Roberts A, Sheahan T, Xiao X, et al. Potent cross-reactive neutralization of SARS coronavirus isolates by human monoclonal antibodies. Proc Natl Acad Sci USA. 2007;104(29):12123-8.

4. Lv Z, Deng YQ, Ye Q, Cao L, Sun CY, Fan C, et al. Structural basis for neutralization of SARS-CoV-2 and SARS-CoV by a potent therapeutic antibody. Science. 2020;369(6510):1505-9.

5. Cheng ZJ, Qu HQ, Tian L, Duan Z, Hakonarson H. COVID-19: look to the future, learn from the past. Viruses. 2020;12(11):1226.

6. Forni D, Cagliani R, Clerici M, Sironi M. Molecular evolution of human coronavirus genomes. Trends Microbiol. 2017;25:35-48.

7. Song Z, Xu Y, Bao L, Zhang L, Yu P, Qu Y, et al. From SARS to MERS, thrusting Coronaviruses into the spotlight. Viruses. 2019;11(1):59.

8. Kandeel M, Ibrahim A, Fayez M, Al-Nazawi M. From SARS and MERS CoVs to SARS-CoV-2: moving toward more biased codon usage in viral structural and nonstructural genes. J Med Virol. 2020;92(6):660-6.

9. Bestle D, Heindl MR, Limburg H, van Van Lam T, Pilgram O, Moulton $\mathrm{H}$, et al. TMPRSS2 and furin are both essential for proteolytic activation of SARS-CoV-2 in human airway cells. Life Sci Alliance. 2020;3(9):e202000786.

10. Hoffmann M, Kleine-Weber H, Schroeder S, Krüger N, Herrler T, Erichsen $\mathrm{S}$, et al. SARS-CoV-2 cell entry depends on ACE2 and TMPRSS2 and is blocked by a clinically proven protease inhibitor. Cell. 2020;181(2):271280.e8.

11. Matsuyama S, Nao N, Shirato K, Kawase M, Saito S, Takayama I, et al. Enhanced isolation of SARS-CoV-2 by TMPRSS2-expressing cells. Proc Natl Acad Sci USA. 2020;117(13):7001-3.

12. Wang C, Li W, Drabek D, Okba NMA, van Haperen R, Osterhaus ADME, et al. A human monoclonal antibody blocking SARS-CoV-2 infection. Nat Commun. 2020;11(1):2251.

13. Zhou D, Duyvesteyn HME, Chen CP, Huang CG, Chen TH, Shih SR, et al. Structural basis for the neutralization of SARS-CoV-2 by an antibody from a convalescent patient. Nat Struct Mol Biol. 2020;27(10):950-8.

14. Shang J, Ye G, Shi K, Wan Y, Luo C, Aihara H, Geng Q, Auerbach A, Li F. Structural basis of receptor recognition by SARS-CoV-2. Nature. 2020;581(7807):221-4

15. Lan J, Ge J, Yu J, Shan S, Zhou H, Fan S, et al. Structure of the SARS-CoV-2 spike receptor-binding domain bound to the ACE2 receptor. Nature. 2020;581(7807):215-20.

16. Rogers TF, Zhao F, Huang D, Beutler N, Burns A, He WT, et al. Isolation of potent SARS-CoV-2 neutralizing antibodies and protection from disease in a small animal model. Science. 2020;369(6506):956-63.

17. Kreye J, Reincke SM, Kornau HC, Sánchez-Sendin E, Corman VM, $\mathrm{Liu} H$, et al. A therapeutic non-self-reactive SARS-CoV-2 antibody protects from lung pathology in a COVID-19 hamster model. Cell. 2020;183(4):1058-69.e19.

18. Chen X, Li R, Pan Z, Qian C, Yang Y, You R, Zhao J, Liu P, Gao L, et al. Human monoclonal antibodies block the binding of SARS-CoV-2 spike protein to angiotensin converting enzyme 2 receptor. Cell Mol Immunol. 2020;17(6):647-9.

19. Li Q, Wu J, Nie J, Zhang L, Hao H, Liu S, et al. The impact of mutations in SARS-CoV-2 spike on viral infectivity and antigenicity. Cell. 2020;182(5):1284-94.e9.

20. Malin JJ, Suárez I, Priesner V, Fätkenheuer G, Rybniker J. Remdesivir against COVID-19 and other viral diseases. Clin Microbiol Rev. 2020;34(1):e00162-e220.

21. Beigel JH, Tomashek KM, Dodd LE, Mehta AK, Zingman BS, Kalil AC, et al. Remdesivir for the treatment of Covid-19-final report. N Engl J Med. 2020;383(19):1813-26.

22. Wang $Y$, Zhang D, Du G, Du R, Zhao J, Jin Y. A Remdesivir in adults with severe COVID-19: a randomised, double-blind, placebo-controlled, multicentre trial. Lancet. 2020;395(10236):1569-78. [Erratum in: Lancet. 2020;395(10238):1694].

23. Prompetchara E, Ketloy C, Palaga T. Immune responses in COVID-19 and potential vaccines: lessons learned from SARS and MERS epidemic. Asian Pac J Allergy Immunol. 2020;38(1):1-9.

24. Johnson AR, McDonald AR, Malay DS. In Pursuit of a SARS-CoV-2 vaccine. J Foot Ankle Surg. 2020;59(6):1133-4.

25. Krammer F. SARS-CoV-2 vaccines in development. Nature. 2020;586(7830):516-27.
26. ter Meulen J, van den Brink EN, Poon LL, Marissen WE, Leung CS, Cox F, et al. Human monoclonal antibody combination against SARS coronavirus: synergy and coverage of escape mutants. PLoS Med. 2006;3(7):e237.

27. Pinto D, Park YJ, Beltramello M, Walls AC, Tortorici MA, Bianchi S, et al. Cross-neutralization of SARS-CoV-2 by a human monoclonal SARS-CoV antibody. Nature. 2020;583(7815):290-5.

28. Yuan M, Wu NC, Zhu X, Lee CD, So RTY, Lv H, et al. A highly conserved cryptic epitope in the receptor binding domains of SARS-CoV-2 and SARS-CoV. Science. 2020;368(6491):630-3.

29. Tian X, Li C, Huang A, Xia S, Lu S, Shi Z, et al. Potent binding of 2019 novel coronavirus spike protein by a SARS coronavirus-specific human monoclonal antibody. Emerg Microbes Infect. 2020;9(1):382-5.

30. Huo J, Le Bas A, Ruza RR, Duyvesteyn HME, Mikolajek H, Malinauskas T, et al. Neutralizing nanobodies bind SARS-CoV-2 spike RBD and block interaction with ACE2. Nat Struct Mol Biol. 2020;27(9):846-54. [Erratum in: Nat Struct Mol Biol. 2020;27(11);1094].

31. Maradei J, Vanesa-Castanó V, Luján-Jaureguibehére M. Terapia con plasma de donantes convalecientes en enfermos graves con COVID19: un llamado a la acción. Revista del Hospital Dr Emilio Ferreyra. 2020;1 (1):e25-30.

32. Cao Y, Su B, Guo X, Sun W, Deng Y, Bao L, et al. Potent neutralizing antibodies against SARS-CoV-2 identified by high-throughput single-cell sequencing of convalescent patients'B Cells. Cell. 2020;182(1):73-84. e16.

33. Hey A. History and practice: antibodies in infectious diseases. In: Crowe $J E$, Boraschi D, Rappuoli R, editors. Antibodies for infectious diseases. Hoboken: Wiley; 2015. p. 1-21. https://doi.org/10.1128/9781555817411. ch1.

34. Both L, White J, Mandal S, Efstratiou A. Access to diphtheria antitoxin for therapy and diagnostics. Euro surveill. 2014;19:20830.

35. Blake PA, Feldman RA, Buchanan TM, Brooks GF, Bennett JV. Serologic therapy of tetanus in the United States, 1965-1971. JAMA. 1976;235:42-4.

36. Menzies BE, Kernodle DS. Passive immunization with antiserum to a nontoxic alpha-toxin mutant from Staphylococcus aureus is protective in a murine model. Infect Immun. 1996;64:1839-41.

37. Lyerly DM, Bostwick E, Binion S, Wilkins T. Passive immunization of hamsters against disease caused by Clostridium difficile by use of bovine immunoglobulin G concentrate. Infect Immun. 1991;59:2215-8.

38. McGuinness AC, Armstrong JG, Felton HM. Hyperimmune whooping cough serum: further studies. J Pediatr. 1944;24:249-58.

39. Bodensteiner JB, Morris H, Howell J, Schochet S. Chronic ECHO type 5 virus meningoencephalitis in X-linked hypogammaglobulinemia: treatment with immune plasma. Neurol. 1979;29:815.

40. McGory RW, Ishitani MB, Oliveira WM, Stevenson WC, McCullough CS, Dickson RC, et al. Improved outcome of orthotopic liver transplantation for chronic hepatitis $B$ cirrhosis with aggressive passive immunization. Transplantation. 1996;61(9):1358-64.

41. Gallagher JR. Use of convalescent measles serum to control measles in a preparatory school. Am J Public Health Nations Health. 1935;25:595-8.

42. Frickhofen N, Abkowitz JL, Safford M, Berry JM, Antunez-de-Mayolo J, Astrow A, et al. Persistent B19 parvovirus infection in patients infected with human immunodeficiency virus type 1 (HIV-1): a treatable cause of anemia in AIDS. Ann Intern Med. 1990;113(12):926-33.

43. Hattwick MA, Corey L, Creecht WB. Clinical use of human globulin immune to rabies vims. J Infect Dis. 1976;133(S2):A266-72.

44. Groothuis JR, Simoes EA, Levin MJ, Hall CB, Long CE, Rodriguez WJ, et al. Prophylactic administration of respiratory syncytial virus immune globulin to high-risk infants and young children. N Engl J Med. 1993:329:1524-30.

45. Weech A. The prophylaxis of varicella with convalescents' serum. JJAMA. 1924;82:1245-6.

46. Walker LM, Burton DR. Passive immunotherapy of viral infections: "super-antibodies" enter the fray. Nat Rev Immunol. 2018;18:297.

47. Levi-Schaffer F, de Marco A. COVID-19 and the revival of passive immunization: antibody therapy for inhibiting SARS-CoV-2 and preventing host cell infection: IUPHAR review: 31. Br J pharmacol. 2020. https://doi. org/10.1111/bph.15359. 
48. Gavor E, Choong YK, Er SY, Sivaraman H. Sivaraman J (2020) Structural basis of SARS-COV-2 and SARS-CoV-antibody interactions. Trends Immunol. 2020;41(11):1006-22.

49. Rajendran K, Krishnasamy N, Rangarajan J, Rathinam J, Natarajan M, Ramachandran A. Convalescent plasma transfusion for the treatment of COVID-19: systematic review. J Med Virol. 2020;92(9):1475-83.

50. Renn A, Fu Y, Hu X, Hall MD, Simeonov A. Fruitful neutralizing antibody pipeline brings hope to defeat SARS-Cov-2. Trends Pharmacol Sci. 2020;41(11):815-29.

51. Zare H, Aghamollaei H, Hosseindokht M, Heiat M, Razei A, Bakherad H. Nanobodies, the potent agents to detect and treat the Coronavirus infections: a systematic review. Mol Cell Probes. 2021;2021(55):101692.

52. Raybould MIJ, Kovaltsuk A, Marks C, Deane CM. CoV-AbDab: the coronavirus antibody database. Bioinformatics. 2020. https://doi.org/10. 1093/bioinformatics/btaa739.

53. Yang L, Liu W, Yu X, Wu M, Reichert JM, Ho M. COVID-19 antibody therapeutics tracker: a global online database of antibody therapeutics for the prevention and treatment of COVID-19. Antib Ther. 2020;3(3):205-12.

54. Lednicky JA, Lauzardo M, Fan ZH, Jutla A, Tilly TB, Gangwar M, et al. Viable SARS-COV-2 in the air of a hospital room with COVID-19 patients. Int J Infect Dis. 2020;100:476-82.

55. Rodriguez-Palacios A, Cominelli F, Basson AR, Pizarro TT, Ilic S. Textile masks and surface covers-A spray simulation method and a "Universal Droplet Reduction Model" against respiratory pandemics. Front Med (Lausanne). 2020;7:260.

56. Chen G, Wu D, Guo W, Cao Y, Huang D, Wang H, et al. Clinical and immunological features of severe and moderate coronavirus disease 2019. J Clin Invest. 2020;130(5):2620-9.

57. García LF. Immune response, inflammation, and the clinical spectrum of COVID-19. Front Immunol. 2020;11:1441.

58. Gu J, Han B, Wang J. COVID-19: gastrointestinal manifestations and potential fecal-oral transmission. Gastroenterology. 2020;158:1518-9.

59. Lamers MM, Beumer J, van der Vaart J, Knoops K, Puschhof J, Breugem $\mathrm{TI}$, et al. SARS-CoV-2 productively infects human gut enterocytes. Science. 2020;369(6499):50-4.

60. Yan R, Zhang Y, Li Y, Xia L, Guo Y, Zhou Q. Structural basis for the recognition of SARS-CoV-2 by full-length human ACE2. Science. 2020;367(6485):1444-8.

61. Conti P, Ronconi G, Caraffa A, Gallenga CE, Ross R, Frydas I, Kritas SK. Induction of pro-inflammatory cytokines (IL-1 and IL-6) and lung inflammation by Coronavirus-19 (COVI-19 or SARS-CoV-2): anti-inflammatory strategies. J Biol Regul Homeost Agents. 2020;34(2):327-31.

62. Guillot L, Le Goffic R, Bloch S, Escriou N, Akira S, Chignard M, Si-Tahar M. Involvement of toll-like receptor 3 in the immune response of lung epithelial cells to double-stranded RNA and influenza A virus. J Biol Chem. 2005;280:5571-80

63. Merad M, Martin JC. Pathological inflammation in patients with COVID19: a key role for monocytes and macrophages. Nat Rev Immunol. 2020;20(6):355-62.

64. Mehta P, McAuley DF, Brown M, Sanchez E, Tattersall RS, Manson JJ, et al. COVID-19: consider cytokine storm syndromes and immunosuppression. Lancet. 2020;395(10229):1033-4.

65. Hu B, Huang S, Yin L. The cytokine storm and COVID-19. J Med Virol. 2020. https://doi.org/10.1002/jmv.26232.

66. Schulert GS, Grom AA. Pathogenesis of macrophage activation syndrome and potential for cytokine-directed therapies. Annu Rev Med. 2015;66:145-59

67. Jafarzadeh A, Chauhan P, Saha B, Jafarzadeh S, Nemati M. Contribution of monocytes and macrophages to the local tissue inflammation and cytokine storm in COVID-19: lessons from SARS and MERS, and potential therapeutic interventions. Life Sci. 2020;257:118102.

68. Shi CS, Nabar NR, Huang NN, Kehrl JH. SARS-Coronavirus Open Reading Frame-8b triggers intracellular stress pathways and activates NLRP3 inflammasomes. Cell Death Discov. 2019;5:101.

69. Freeman TL, Swartz TH. Targeting the NLRP3 Inflammasome in Severe COVID-19. Front Immunol. 2020;1 1:1518.

70. Li JY, Liao CH, Wang Q, Tan YJ, Luo R, Qiu Y, Ge XY. The ORF6, ORF8 and nucleocapsid proteins of SARS-CoV-2 inhibit type I interferon signaling pathway. Virus Res. 2020;286:198074.
71. Wu C, Chen X, Cai Y, Xia J, Zhou X, Xu S, et al. Risk factors associated with acute respiratory distress syndrome and death in patients with coronavirus disease 2019 pneumonia in Wuhan, China. JAMA Intern Med. 2020;180(7):934-43.

72. Barton LM, Duval EJ, Stroberg E, Ghosh S, Mukhopadhyay S. COVID19 Autopsies, Oklahoma, USA. Am J Clin Pathol. 2020;153(6):725-33. [Erratum in: Am J Clin Pathol. 2020;153(6):852]

73. Zhang W, Zhao Y, Zhang F, Wang Q, Li T, Liu Z, et al. The use of antiinflammatory drugs in the treatment of people with severe coronavirus disease 2019 (COVID-19): the perspectives of clinical immunologists from China. Clin Immunol. 2020;214:108393.

74. Zheng M, Gao Y, Wang G, Song G, Liu S, Sun D, Xu Y, Tian Z. Functional exhaustion of antiviral lymphocytes in COVID-19 patients. Cell Mol Immunol. 2020;17(5):533-5.

75. André P, Denis C, Soulas C, Bourbon-Caillet C, Lopez J, Arnoux T, et al. Anti-NKG2A mAb is a checkpoint inhibitor that promotes anti-tumor immunity by unleashing both T and NK cells. Cell. 2018;175:1731-43.

76. Li F, Wei H, Wei H, Gao Y, Xu L, Yin W, Sun R, Tian Z. Blocking the natural killer cell inhibitory receptor NKG2A increases activity of human natural killer cells and clears hepatitis B virus infection in mice. Gastroenterology. 2013;144:392-401.

77. Wilk AJ, Rustagi A, Zhao NQ, Roque J, Martínez-Colón GJ, McKechnie JL, et al. A single-cell atlas of the peripheral immune response in patients with severe COVID-19. Nat Med. 2020;26(7):1070-6.

78. Gao T, Hu M, Zhang X, Li H, Zhu L, Liu H, et al. Highly pathogenic coronavirus $\mathrm{N}$ protein aggravates lung injury by MASP-2-mediated complement over-activation. MedRxiv. 2020. https://doi.org/10.1101/ 2020.03.29.20041962.

79. Barnes BJ, Adrover JM, Baxter-Stoltzfus A, Borczuk A, Cools-Lartique J, Crawford JM, et al. Targeting potential drivers of COVID-19: Neutrophil extracellular traps. J Exp Med. 2020;217(6):e20200652.

80. Dzik S. Complement and coagulation: cross talk through time. Transf Med Rev. 2019:33(4):199-206.

81. Krarup A, Wallis R, Presanis JS, Gál P, Sim RRB. Simultaneous activation of complement and coagulation by MBL-associated serine protease 2 . PLOS ONE. 2007;2:e623.

82. Ritis K, Doumas M, Mastellos D, Micheli A, Giaglis S, Magotti P, et al. A novel $\mathrm{C} 5$ a receptor-tissue factor cross-talk in neutrophils links innate immunity to coagulation pathways. J Immunol. 2006;177(7):4794-802.

83. Wiedmer T, Esmon CT, Sims PJ. Complement proteins C 5b-9 stimulate procoagulant activity through platelet prothrombinase. Blood. 1986;68(4):875-80

84. Rodriguez-Zhurbenko N, Quach TD, Hopkins TJ, Rothstein TL, Hernandez AM. Human B-1 Cells and B-1 cell antibodies change with advancing age. Front Immunol. 2019;10:483.

85. Java A, Apicelli AJ, Liszewski MK, Coler-Reilly A, Atkinson JP, Kim AH, Kulkarni HS. The complement system in COVID-19: friend and foe? JCl Insight. 2020;5(15):e140711.

86. Imai Y, Kuba K, Neely GG, Yaghubian-Malhami R, Perkmann T, van Loo G, et al. Identification of oxidative stress and Toll-like receptor 4 signaling as a key pathway of acute lung injury. Cell. 2008;133(2):235-49.

87. Vijay R, Hua X, Meyerholz DK, Miki Y, Yamamoto K, Gelb M, et al. Critical role of phospholipase A2 group IID in age-related susceptibility to severe acute respiratory syndrome-CoV infection. J Exp Med. 2015:212(11):1851-68.

88. Liu L, Wei Q, Lin Q, Fang J, Wang H, Kwok H, et al. Anti-spike IgG causes severe acute lung injury by skewing macrophage responses during acute SARS-CoV infection. JCI Insight. 2019;4(4):e123158.

89. Felgenhauer U, Schoen A, Gad HH, Hartmann R, Schaubmar AR, Failing $\mathrm{K}$, et al. Inhibition of SARS-CoV-2 by type I and type III interferons. J Biol Chem. 2020;295(41):13958-64.

90. Sa Ribero M, Jouvenet N, Dreux M, Nisole S. Interplay between SARS-CoV-2 and the type I interferon response. PLoS Pathog. 2020;16(7):e1008737.

91. Diao B, Wang C, Tan Y, Chen X, Liu Y, Ning L, et al. Reduction and functional exhaustion of T cells in patients with Coronavirus Disease 2019 (COVID-19). Front Immunol. 2020;11:827.

92. Herrmann M, Schulte S, Wildner NH, Wittner M, Brehm TT, Ramharter $\mathrm{M}$, et al. Analysis of co-inhibitory receptor expression in COVID-19 infection compared to acute Plasmodium falciparum malaria: LAG-3 
and TIM-3 Correlate with T Cell activation and course of disease. Front Immunol. 2020;11:1870.

93. Wherry EJ, Kurachi M. Molecular and cellular insights into T cell exhaustion. Nat Rev Immunol. 2015;15(8):486-99.

94. Anderson AC, Joller N, Kuchroo VK. Lag-3, Tim-3, and TIGIT: co-inhibitory receptors with specialized functions in immune regulation. Immunity. 2016:44:989-1004.

95. Kalpakci Y, Hacibekiroglu T, Trak G, Karacaer C, Demirci T, Kocayigit H, et al. Comparative evaluation of memory T cells in COVID-19 patients and the predictive role of CD4+CD8+ double positive T lymphocytes as a new marker. Rev Assoc Med Bras. 2020;66(12):1666-72.

96. Chen Z, Wherry EJ.T cell responses in patients with COVID-19. Nat Rev Immunol. 2020;20(9):529-36.

97. Moon C. Fighting COVID-19 exhausts T cells. Nat Rev Immunol. 2020;20(5):277.

98. Sattler A, Angermair S, Stockmann H, Heim KM, Khadzhynov D, Treskatsch $\mathrm{S}$, et al. SARS-CoV-2-specific T cell responses and correlations with COVID-19 patient predisposition. J Clin Invest. 2020;130(12):6477-89.

99. Terpos E, Ntanasis-Stathopoulos I, Elalamy I, Kastritis E, Sergentanis TN, Politou M, et al. Hematological findings and complications of COVID-19. Am J Hematol. 2020;2020(95):834-47.

100. Xu H, Zhong L, Deng J, Peng J, Dan H, Zeng X, et al. (2020) High expression of ACE2 receptor of 2019-nCoV on the epithelial cells of oral mucosa. Int J Oral Sci. 2020;12(1):1-5.

101. Liao M, Liu Y, Yuan J, Wen Y, Xu G, Zhao J, et al. Single-cell landscape of bronchoalveolar immune cells in patients with COVID-19. Nat Med. 2020;26(6):842-4.

102. Peng Y, Mentzer AJ, Liu G, Yao X, Yin Z, Dong D, et al. Broad and strong memory CD4+ and CD8+T cells induced by SARS-CoV-2 in UK convalescent individuals following COVID-19. Nat Immunol. 2020;21(11):1336-45.

103. Neidleman J, Luo X, Frouard J, Xie G, Gill G, Stein ES, et al. SARS-CoV2-specific $T$ cells exhibit phenotypic features of helper function, lack of terminal differentiation, and high proliferation potential. Cell Reports Med. 2020;1 (6):100081.

104. Zhang Y, Zhang J, Chen Y, Luo B, Yuan Y, Huang F, et al. The ORF8 protein of SARS-CoV-2 mediates immune evasion through potently downregulating MHC-I. bioRxiv. 2020. https://doi.org/10.1101/2020.05.24.111823.

105. Tirado SMC, Yoon KJ. Antibody-dependent enhancement of virus infection and disease. Viral Immun. 2003;16:69-86.

106. Takada A, Kawaoka Y. Antibody-dependent enhancement of viral infection: molecular mechanisms and in vivo implications. Rev Med Virol. 2003;13:387-98.

107. Kam YW, Kien F, Roberts A, Cheung YC, Lamirande EW, Vogel L, et al. Antibodies against trimeric $S$ glycoprotein protect hamsters against SARS-CoV challenge despite their capacity to mediate FcyRlldependent entry into B cells in vitro. Vaccine. 2007;25:729-40.

108. Yip MS, Leung NH, Cheung CY, Li PH, Lee HH, Daëron M, et al. Antibodydependent infection of human macrophages by severe acute respiratory syndrome coronavirus. Virol J. 2014;11:82.

109. Agrawal AS, Tao X, Algaissi A, Garron T, Narayanan K, Peng BH, et al. Immunization with inactivated Middle East Respiratory Syndrome coronavirus vaccine leads to lung immunopathology on challenge with live virus. Hum Vaccin Immunother. 2016;12(9):2351-6.

110. Vennema H, De Groot R, Harbour D, Dalderup M, Gruffydd-Jones T, Horzinek M, Spaan W. Early death after feline infectious peritonitis virus challenge due to recombinant vaccinia virus immunization. J Virol. 1990;64:1407-9.

111. Takada A, Watanabe S, Okazaki K, Kida H, Kawaoka Y. Infectivity-enhancing antibodies to Ebola virus glycoprotein. J Virol. 2001;75:2324-30.

112. Beck Z, Prohászka Z, Füst G. Traitors of the immune system —enhancing antibodies in HIV infection: their possible implication in HIV vaccine development. Vaccine. 2008;26:3078-85.

113. Negro F. Is antibody-dependent enhancement playing a role in COVID-19 pathogenesis? Swiss Med Wkly. 2020;150:w20249.

114. Wu F, Yan R, Liu M, Liu Z, Wang Y, Luan D, et al. Antibody-dependent enhancement (ADE) of SARS-CoV-2 infection in recovered COVID-19 patients: studies based on cellular and structural biology analysis. MedRxiv. 2020. https://doi.org/10.1101/2020.10.08.20209114.
115. Kaufmann SH. Immunology's foundation: the 100-year anniversary of the Nobel Prize to Paul Ehrlich and Elie Metchnikoff. Nature Immunol. 2008:9:705-12.

116. Ehrlich P. Experimentelle untersuchungen über immunität. I. Ueber ricin. DMW-Deutsche Medizinische Wochenschrift. 1981;17:976-9.

117. Muhammed $Y$. The best lgG subclass for the development of therapeutic monoclonal antibody drugs and their commercial production: a review. Immunome Res. 2020;16:1-12.

118. Le Basle Y, Chennell P, Tokhadze N, Astier A, Sautou V. Physicochemical stability of monoclonal antibodies: a review. J Pharm Sci. 2020;109(1):169-90.

119. Harris R. Heterogeneity of recombinant antibodies: linking structure to function. Mire-Sluis AR, editor. State of the art analytical methods for the characterization of biological. Products and assessment of comparability. (Dev Biol, Basel, Karger, 200S, vol 122, pp 117-127; 2005).

120. Arakawa S, Suzukawa M, Watanabe K, Kobayashi K, Matsui H, Nagai H, et al. Secretory immunoglobulin A induces human lung fibroblasts to produce inflammatory cytokines and undergo activation. Clin Exp Immunol. 2019;195(3):287-301.

121. Yu HQ, Sun BQ, Fang ZF, Zhao JC, Liu XY, Li YM, et al. Distinct features of SARS-CoV-2-specific IgA response in COVID-19 patients. Eur Respir J. 2020;56(2):2001526.

122. Gutzeit C, Chen K, Cerutti A. The enigmatic function of IgD: some answers at last. Eur J Immunol. 2018;48(7):1101-13.

123. Chen K, Xu W, Wilson M, He B, Miller NW, Bengtén E, et al. Immunoglobulin $D$ enhances immune surveillance by activating antimicrobial, proinflammatory and B cell-stimulating programs in basophils. Nat Immunol. 2009;10(8):889-98.

124. Pier GB, Lyczak JB, Wetzler LM. Immunology, infection, and immunity. Washington: ASM press; 2004.

125. Vidarsson G, Dekkers G, Rispens T. IgG subclasses and allotypes: from structure to effector functions. Front Immunol. 2014;5:520.

126. Zinkernagel RM, LaMarre A, Ciurea A, Hunziker L, Ochsenbein AF, McCoy KD, et al. Neutralizing antiviral antibody responses. Adv Immunol. 2001;79:1-53.

127. Guo L, Ren L, Yang $S$, Xiao M, Chang D, Yang F, et al. Profiling early humoral response to diagnose novel coronavirus disease (COVID-19). Clin Infect Dis. 2020;71(15):778-85.

128. Long QX, Liu BZ, Deng HJ, Wu CG, Deng K, Chen YK, et al. Antibody responses to SARS-CoV-2 in patients with COVID-19. Nat Med. 2020;26(6):845-8.

129. Padoan A, Sciacovelli L, Basso D, Negrini D, Zuin S, Cosma C, et al. IgA-Ab response to spike glycoprotein of SARS-CoV-2 in patients with COVID-19: a longitudinal study. Clin Chim Acta. 2020;507:164-6.

130. Fourati S, Hue S, Pawlotsky JM, Mekontso-Dessap A, de Prost N. SARSCoV-2 viral loads and serum IgA/lgG immune responses in critically ill COVID-19 patients. Intensive Care Med. 2020;46(9):1781-3.

131. Lu LL, Suscovich TJ, Fortune SM, Alter G. Beyond binding: antibody effector functions in infectious diseases. Nat Rev Immunol. 2018;18:46

132. Natarajan H, Crowley AR, Butler SE, XU S, Weiner JA, Bloch EM, et al. SARS-CoV-2 antibody signatures robustly predict diverse antiviral functions relevant for convalescent plasma therapy. medRxiv. 2020. https:// doi.org/10.1101/2020.09.16.20196154.

133. Schroeder HW Jr, Cavacini L. Structure and function of immunoglobulins. J Allergy Clin Immunol. 2010;125(2 Suppl 2):S41-52.

134. Ni L, Ye F, Cheng ML, Feng Y, Deng YQ, Zhao H, et al. Detection of SARSCoV-2-specific humoral and cellular immunity in COVID-19 convalescent individuals. Immunity. 2020;52(6):971-7.e3.

135. Ju B, Zhang Q, Ge J, Wang R, Sun J, Ge X, et al. Human neutralizing antibodies elicited by SARS-CoV-2 infection. Nature. 2020;584(7819):115-9.

136. Brouwer PJM, Caniels TG, van der Straten K, Snitselaar JL, Aldon Y, Bangaru S, et al. Potent neutralizing antibodies from COVID-19 patients define multiple targets of vulnerability. Science. 2020;369(6504):643-50.

137. Kreer C, Zehner M, Weber T, Ercanoglu MS, Gieselmann L, Rohde C, et al. Longitudinal isolation of potent near-germline SARS-CoV-2-neutralizing antibodies from COVID-19 patients. Cell. 2020;182(4):843-54.e12.

138. Barnes CO, West AP Jr, Huey-Tubman KE, Hoffmann MAG, Sharaf NG, Hoffman PR, et al. Structures of human antibodies bound to 
SARS-CoV-2 spike reveal common epitopes and recurrent features of antibodies. Cell. 2020;182(4):828-42.e16.

139. Shu H, Wang S, Ruan S, Wang Y, Zhang J, Yuan Y, et al. Dynamic changes of antibodies to SARS-CoV-2 in COVID-19 patients at early stage of outbreak. Virol Sin. 2020;27:1-8.

140. Du S, Cao Y, Zhu Q, Wang G, Du X, He R, et al. Structures of potent and convergent neutralizing antibodies bound to the SARS-CoV-2 spike unveil a unique epitope responsible for exceptional potency. bioRxiv. 2020. https://doi.org/10.1101/2020.07.09.195263.

141. Chi X, Yan R, Zhang J, Zhang G, Zhang Y, Hao M, et al. A neutralizing human antibody binds to the $\mathrm{N}$-terminal domain of the spike protein of SARS-CoV-2. Science. 2020;369(6504):650-5.

142. Robbiani DF, Gaebler C, Muecksch F, Lorenzi JCC, Wang Z, Cho A, et al. Convergent antibody responses to SARS-CoV-2 in convalescent individuals. Nature. 2020;584(7821):437-42.

143. Zost SJ, Gilchuk P, Chen RE, Case JB, Reidy JX, Trivette A, et al. Rapid isolation and profiling of a diverse panel of human monoclonal antibodies targeting the SARS-CoV-2 spike protein. Nat Med. 2020;26(9):1422-7.

144. Seydoux E, Homad LJ, MacCamy AJ, Parks KR, Hurlburt NK, Jennewein MF, et al. Analysis of a SARS-CoV-2-infected individual reveals development of potent neutralizing antibodies with limited somatic mutation. Immunity. 2020;53(1):98-105.e5.

145. Hansen J, Baum A, Pascal KE, Russo V, Giordano S, Wloga E, et al. Studies in humanized mice and convalescent humans yield a SARS-CoV-2 antibody cocktail. Science. 2020;369(6506):1010-4.

146. Wu Y, Wang F, Shen C, Peng W, Li D, Zhao C, et al. A noncompeting pair of human neutralizing antibodies block COVID-19 virus binding to its receptor ACE2. Science. 2020;368(6496):1274-8.

147. Shen C, Wang Z, Zhao F, Yang Y, Li J, Yuan J, et al. Treatment of 5 critically ill patients with COVID-19 with convalescent plasma. JAMA. 2020;323(16):1582-9.

148. Zeng QL, Yu ZJ, Gou JJ, Li GM, Ma SH, Zhang GF, et al. Effect of convalescent plasma therapy on viral shedding and survival in patients with coronavirus disease 2019. J Infect Dis. 2020;222(1):38-43.

149. Zhang B, Liu S, Tan T, Huang W, Dong Y, Chen L, et al. Treatment with convalescent plasma for critically ill patients with severe acute respiratory syndrome coronavirus 2 infection. Chest. 2020;158(1):e9-13.

150. Ye M, Fu D, Ren Y, Wang F, Wang D, Zhang F, Xia X, Lv T. Treatment with convalescent plasma for COVID-19 patients in Wuhan. China J Med Virol. 2020;92(10):1890-901.

151. Ahn JY, Sohn Y, Lee SH, Cho Y, Hyun JH, Baek YJ, et al. Use of convalescent plasma therapy in two COVID-19 patients with acute respiratory distress syndrome in Korea. J Korean Med Sci. 2020;35(14):e149.

152. Duan K, Liu B, Li C, Zhang H, Yu T, Qu J, et al. Effectiveness of convalescent plasma therapy in severe COVID-19 patients. Proc Natl Acad Sci USA. 2020;117(17):9490-6.

153. Li L, Zhang W, Hu Y, Tong X, Zheng S, Yang J, et al. Effect of convalescent plasma therapy on time to clinical improvement in patients with severe and life-threatening COVID-19: a randomized clinical trial. JAMA. 2020;324(5):460-70

154. Salazar E, Kuchipudi SV, Christensen PA, Eagar TN, Yi X, Zhao P, et al. Relationship between anti-spike protein antibody titers and SARSCoV-2 in vitro virus neutralization in convalescent plasma. biorxiv. 2020. https://doi.org/10.1101/2020.06.08.138990.

155. Perotti C, Baldanti F, Bruno R, del Fante C, Seminari E, Casari S, et al. Covid-19 plasma task force, Mortality reduction in 46 severe Covid-19 patients treated with hyperimmune plasma. A proof of concept single arm multicenter trial. Haematologica. 2020; 23:haematol.2020.261784.

156. Ibrahim D, Dulipsingh L, Zapatka L, Eadie R, Crowell R, Williams K, et al. Factors associated with good patient outcomes following convalescent plasma in COVID-19: a prospective phase II clinical trial. Infect Dis Ther. 2020;20:1-14

157. Abolghasemi H, Eshghi P, Cheraghali AM, Imani Fooladi AA, Bolouki Moghaddam F, Imanizadeh S, et al. Clinical efficacy of convalescent plasma for treatment of COVID-19 infections: results of a multicenter clinical study. Transf Apher Sci. 2020;59(5):102875.

158. Hegerova L, Gooley TA, Sweerus KA, Maree C, Bailey N, Bailey M, et al. Use of convalescent plasma in hospitalized patients with COVID-19: case series. Blood. 2020;136(6):759-62.
159. Liu STH, Lin HM, Baine I, Wajnberg A, Gumprecht JP, Rahman F, et al. Convalescent plasma treatment of severe COVID-19: a propensity score-matched control study. Nat Med. 2020;26(11):1708-13.

160. Xia X, Li K, Wu L, Wang Z, Zhu M, Huang B, et al. Improved clinical symptoms and mortality among patients with severe or critical COVID-19 after convalescent plasma transfusion. Blood. 2020;136(6):755-9.

161. Joyner MJ, Wright RS, Fairweather D, Senefeld JW, Bruno KA, Klassen SA, et al. Early safety indicators of COVID-19 convalescent plasma in 5000 patients. J Clin Invest. 2020;130(9):4791-7.

162. Hartman WR, Hess AS, Connor JP. Hospitalized COVID-19 patients treated with convalescent plasma in a mid-size city in the Midwest. Transl Med Commun. 2020;5(1):17.

163. Brown BL, McCullough J. Treatment for emerging viruses: convalescent plasma and COVID-19. Transf Apher Sci. 2020;59(3):102790.

164. Luke TC, Kilbane EM, Jackson JL, Hoffman SL. Meta-analysis: convalescent blood products for Spanish influenza pneumonia: a future H5N1 treatment? Ann Intern Med. 2006;145(8):599-609.

165. Cheng Y, Wong R, Soo YO, Wong WS, Lee CK, Ng MH, et al. Use of convalescent plasma therapy in SARS patients in Hong Kong. Eur J Clin Microbiol Infect Dis. 2005;24(1):44-6.

166. Focosi D, Anderson AO, Tang JW, Tuccori M. Convalescent plasma therapy for COVID-19: state of the art. Clin Microbiol Rev. 2020;33(4):e00072-e120

167. Cunningham AC, Goh HP, Koh D. Treatment of COVID-19: old tricks for new challenges. Crit Care. 2020;24(1):91.

168. Arabi YM, Hajeer AH, Luke T, Raviprakash K, Balkhy H, Johani S, et al. Feasibility of using convalescent plasma immunotherapy for MERS-CoV Infection. Saudi Arabia Emerg Infect Dis. 2016;22(9):1554-61.

169. Klein SL, Pekosz A, Park HS, Ursin RL, Shapiro JR, Benner SE, et al. Sex, age, and hospitalization drive antibody responses in a COVID-19 convalescent plasma donor population. J Clin Invest. 2020;130(11):6141-50.

170. Franchini M, Marano G, Velati C, Pati I, Pupella S, Liumbruno GM. Operational protocol for donation of anti-COVID-19 convalescent plasma in Italy. Vox Sang. 2020. https://doi.org/10.1111/vox.12940.

171. Mair-Jenkins J, Saavedra-Campos M, Baillie JK, Cleary P, Khaw FM, Lim WS, et al. The effectiveness of convalescent plasma and hyperimmune immunoglobulin for the treatment of severe acute respiratory infections of viral etiology: a systematic review and exploratory meta-analysis. J Infect Dis. 2015;211 (1):80-90.

172. Lung T, Kazatchkine MD, Risch L, Risch M, Nydegger UE. A consideration of convalescent plasma and plasma derivatives in the care of Severelyill patients with COVID-19. Transfus Apher Sci. 2020;59(5):102936.

173. Singh N, Pandey A. Blood plasma from survivors of COVID-19: a novel and next frontier approach to fight against pandemic coronavirus. Int J Immunol Immunother. 2020;7:045.

174. Lee WT, Girardin RC, Dupuis AP, Kulas KE, Payne AF, Wong SJ, et al. Neutralizing antibody responses in COVID-19 convalescent sera. J Infect Dis. 2021;223(1):47-55.

175. Girardin RC, Dupuis AP, Payne AF, Sullivan TJ, Strauss D, Parker MM, McDonough KA. Temporal analysis of serial donations reveals decrease in neutralizing capacity and justifies revised qualifying criteria for COVID-19 convalescent plasma. J Inf Dis. 2021. https://doi.org/10.1093/ infdis/ijaa803.

176. Shanmugaraj B, Siriwattananon K, Wangkanont K, Phoolcharoen W. Perspectives on monoclonal antibody therapy as potential therapeutic intervention for Coronavirus disease-19 (COVID-19). Asian Pac J Allergy Immunol. 2020;38(1):10-8.

177. Hassan AO, Case JB, Winkler ES, Thackray LB, Kafai NM, Bailey AL, et al. A SARS-CoV-2 infection model in mice demonstrates protection by neutralizing antibodies. Cell. 2020;182(3):744-753.e4.

178. Piccoli L, Park YJ, Tortorici MA, Czudnochowski N, Walls AC, Beltramello $M$, et al. Mapping neutralizing and immunodominant sites on the SARS-CoV-2 Spike Receptor-Binding Domain by structure-guided highresolution serology. Cell. 2020;183(4):1024-1042.e21.

179. Bracken CJ, Lim SA, Solomon P, Rettko NJ, Nguyen DP, Zha BS, et al. Biparatopic and multivalent $\mathrm{VH}$ domains block ACE2 binding and neutralize SARS-CoV-2. Nat Chem Biol. 2021;17:113-21.

180. Clark SA, Clark LE, Pan J, Coscia A, McKay LGA, Shankar S, et al. Molecular basis for a germline-biased neutralizing antibody response to SARSCoV-2. bioRxiv. 2020. https://doi.org/10.1101/2020.11.13.381533. 
181. El Debs B, Utharala R, Balyasnikova IV, Griffiths AD, Merten CA. Functional single-cell hybridoma screening using droplet-based microfluidics. Proc Natl Acad Sci USA. 2012;109(29):11570-5.

182. Niu X, Zhao L, Qu L, Yao Z, Zhang F, Yan Q. Convalescent patient-derived monoclonal antibodies targeting different epitopes of $E$ protein confer protection against Zika virus in a neonatal mouse model. Emerg Microbes Infect. 2019;8(1):749-59.

183. Walker LM, Phogat SK, Chan-Hui PY, Wagner D, Phung P, Goss JL, et al. Broad and potent neutralizing antibodies from an African donor reveal a new HIV-1 vaccine target. Science. 2009;326(5950):285-9.

184. McCallum M, Walls AC, Bowen JE, Corti D, Veesler D. Structure-guided covalent stabilization of coronavirus spike glycoprotein trimers in the closed conformation. Nat Struct Mol Biol. 2020;27(10):942-9.

185. Duan L, Zheng Q, Zhang H, Niu Y, Lou Y, Wang H. The SARS-CoV-2 spike glycoprotein biosynthesis, structure, function, and antigenicity: implications for the design of spike-based vaccine immunogens. Front Immunol. 2020;11:576622.

186. Sternberg A, Naujokat C. Structural features of coronavirus SARS-CoV-2 spike protein: targets for vaccination. Life Sci. 2020;257:118056.

187. Zhang T, Wu Q, Zhang Z. Probable pangolin origin of SARS-CoV-2 associated with the COVID-19 outbreak. Curr Biol. 2020;30(7):1346-1351.e2. [Erratum in: Curr. Biol. 2020;30(8):1578].

188. Wrapp D, Wang N, Corbett KS, Goldsmith JA, Hsieh CL, Abiona O, et al. Cryo-EM structure of the 2019-nCoV spike in the prefusion conformation. Science. 2020;367(6483):1260-3.

189. Xu C, Wang Y, Liu C, Zhang C, Han W, Hong X, et al. Conformational dynamics of SARS-CoV-2 trimeric spike glycoprotein in complex with receptor ACE2 revealed by cryo-EM. Sci Adv. 2020;7:eabe5575.

190. Henderson R, Edwards RJ, Mansouri K, Janowska K, Stalls V, Gobeil SMC, et al. Controlling the SARS-CoV-2 spike glycoprotein conformation. Nat Struct Mol Biol. 2020;27(10):925-33.

191. Bruhns P, lannascoli B, England P, Mancardi DA, Fernandez N, Jorieux S, Daëron M. Specificity and affinity of human Fcgamma receptors and their polymorphic variants for human IgG subclasses. Blood. 2009:113(16):3716-25.

192. Walls AC, Park YJ, Tortorici MA, Wall A, McGuire AT, Veesler D. Structure, function, and antigenicity of the SARS-CoV-2 spike glycoprotein. Cell. 2020; 181(2);281-292.e6. [Erratum in: Cell 2020;183(6):1735]

193. Yu F, Xiang R, Deng X, Wang L, Yu Z, Tian S, et al. Receptor-binding domain-specific human neutralizing monoclonal antibodies against SARS-CoV and SARS-CoV-2. Signal Transduct Target Ther. 2020;5(1):212.

194. Barnes CO, Jette CA, Abernathy ME, Dam KA, Esswein SR, Gristick HB, et al. SARS-CoV-2 neutralizing antibody structures inform therapeutic strategies. Nature. 2020;588(7839):682-7.

195. Lu R, Zhao X, Li J, Niu P, Yang B, Wu H, et al. Genomic characterisation and epidemiology of 2019 novel coronavirus: implications for virus origins and receptor binding. Lancet. 2020;395(10224):565-74.

196. Rujas E, Kucharska I, Tan YZ, Benlekbir S, Cui H, Zhao T, et al. Multivalency transforms SARS-CoV-2 antibodies into broad and ultrapotent neutralizers. bioRxiv. 2020. https://doi.org/10.1101/2020.10.15.341636.

197. Prabakaran P, Gan J, Feng Y, Zhu Z, Choudhry V, Xiao X, et al. Structure of severe acute respiratory syndrome coronavirus receptorbinding domain complexed with neutralizing antibody. J Biol Chem. 2006;281(23):15829-36.

198. Hwang WC, Lin Y, Santelli E, Sui J, Jaroszewski L, Stec B, et al. Structural basis of neutralization by a human anti-severe acute respiratory syndrome spike protein antibody, 80R. J Biol Chem. 2006;281(45):34610-6.

199. Acharya P, Williams W, Henderson R, Janowska K, Manne K, Parks R, et al. A glycan cluster on the SARS-CoV-2 spike ectodomain is recognized by Fab-dimerized glycan-reactive antibodies. bioRxiv. 2020. https://doi. org/10.1101/2020.06.30.178897.

200. Jones BE, Brown-Augsburger PL, Corbett KS, Westendorf K, Davies J, Cujec TP, et al. LY-CoV555, a rapidly isolated potent neutralizing antibody, provides protection in a non-human primate model of SARS-CoV-2 infection. bioRxiv. 2020. https://doi.org/10.1101/2020.09.30 318972

201. Baum A, Fulton BO, Wloga E, Copin R, Pascal KE, Russo V, et al. Antibody cocktail to SARS-CoV-2 spike protein prevents rapid mutational escape seen with individual antibodies. Science. 2020;369(6506):1014-8.
202. Chen P Nirula A, Heller B, Gottlieb RL, Boscia J Morris J et al SARSCoV-2 neutralizing antibody LY-CoV555 in outpatients with Covid-19. N Engl J Med. 2021;384(3):229-37.

203. ACTIV-3/TICO LY-CoV555 Study Group, Lundgren JD, Grund B, Barkauskas CE, Holland TL, Gottlieb RL, et al. A neutralizing monoclonal antibody for hospitalized patients with Covid-19. N Engl J Med. 2021:384(10):905-14.

204. Shi R, Shan C, Duan X, Chen Z, Liu P, Song J, et al. A human neutralizing antibody targets the receptor-binding site of SARS-CoV-2. Nature. 2020;584(7819):120-4

205. Liu L, Wang P, Nair MS, Yu J, Rapp M, Wang Q. Potent neutralizing antibodies against multiple epitopes on SARS-CoV-2 spike. Nature. 2020;584(7821):450-6.

206. Rapp M, Guo Y, Reddem ER, Liu L, Wang P, Yu J, et al. Modular basis for potent SARS-CoV-2 neutralization by a prevalent VH1-2-derived antibody class. Cell Rep. 2021. https://doi.org/10.1016/j.celrep.2021.108950.

207. Cerutti G, Guo Y, Zhou T, Gorman J, Lee M, Rapp M, et al. Potent SARSCoV-2 neutralizing antibodies directed against spike $\mathrm{N}$-terminal domain target a single supersite. Cell Host Microbe. 2021. https://doi.org/10. 1016/j.chom.2021.03.005.

208. Zost SJ, Gilchuk P, Case JB, Binshtein E, Chen RE, Nkolola JP, et al. Potently neutralizing and protective human antibodies against SARSCoV-2. Nature. 2020;584(7821):443-9.

209. Li W, Schäfer A, Kulkarni SS, Liu X, Martinez DR, Chen C, et al. High potency of a bivalent human VH domain in SARS-CoV-2 animal models. Cell. 2020;183(2):429-441.e16.

210. Zhang C, Wang Y, Zhu Y, Liu C, Gu C, Xu S, et al. Development and structural basis of a two-MAb cocktail for treating SARS-CoV-2 infections. Nat Commun. 2021;12(1):264.

211. Korber B, FischerWM, Gnanakaran S, Yoon H, Theiler J, AbfaltererW, et al. Track ing changes in SARS-CoV-2 Spike: evidence that D614G increases infectivity of the COVID-19 virus. Cell. 2020;182(4):812-827.e19.

212. Bertoglio F, Fühner $\bigvee$, Ruschig M, Heine PA, Rand U, Klünemann T, et al. A SARS-CoV-2 neutralizing antibody selected from COVID-19 patients by phage display is binding to the ACE2-RBD interface and is tolerant to known RBD mutations. bioRxiv. 2020. https://doi.org/10.1101/2020. 12.03.409318.

213. Yao H, Sun Y, Deng YQ, Wang N, Tan Y, Zhang NN, et al. Rational development of a human antibody cocktail that deploys multiple functions to confer Pan-SARS-CoVs protection. Cell Res. 2021:31:25-36.

214. Wan J, Xing S, Ding L, Wang Y, Gu C, Wu Y, et al. Human-IgG-neutralizing monoclonal antibodies block the SARS-CoV-2 infection. Cell Rep. 2020;32(3):107918.

215. Shervani Z, Khan I, Khan T, Qazi UY. World's fastest supercomputer picks COVID-19 drug. Adv Infect Dis. 2020;10(3):211.

216. Bournazos S, Ravetch JV. Anti-retroviral antibody FcyR-mediated effector functions. Immunol Rev. 2017:275(1):285-95.

217. Shields RL, Namenuk AK, Hong K, Meng YG, Rae J, Briggs J, et al. High resolution mapping of the binding site on human lgG1 for $F C$ gamma RI, Fc gamma RII, Fc gamma RIII, and FCRn and design of IgG1 variants with improved binding to the Fc gamma R. J Biol Chem. 2001;276(9):6591-604

218. Wang B, Yang C, Jin X, Du Q, Wu H, Dall'Acqua W, Mazor Y. Regulation of antibody-mediated complement-dependent cytotoxicity by modulating the intrinsic affinity and binding valency of lgG for target antigen. MAbs. 2020;12(1):1690959.

219. Popp O, Moser S, Zielonka J, Rüger P, Hansen S, Plöttner O. Development of a pre-glycoengineered $\mathrm{CHO}-\mathrm{K} 1$ host cell line for the expression of antibodies with enhanced Fc mediated effector function. MAbs. 2018;10(2):290-303.

220. Krammer F, Palese P, Steel J. Advances in universal influenza virus vaccine design and antibody mediated therapies based on conserved regions of the hemagglutinin. Curr Top Microbiol Immunol. 2015:386:301-21.

221. Shields RL, Lai J, Keck R, Oconnell LY, Hong K, Meng YG, et al. Lack of fucose on human lgG1 N-linked oligosaccharide improves binding to human Fcgamma RIII and antibody-dependent cellular toxicity. J Biol Chem. 2002;277(30):26733-40.

222. Shinkawa T, Nakamura K, Yamane N, Shoji-Hosaka E, Kanda Y, Sakurada $M$, et al. The absence of fucose but not the presence of galactose or bisecting $\mathrm{N}$-acetylglucosamine of human lgG1 complex-type 
oligosaccharides shows the critical role of enhancing antibodydependent cellular cytotoxicity. J Biol Chem. 2003;278:3466-73.

223. Tortorici MA, Beltramello M, Lempp FA, Pinto D, Dang HV, Rosen LE, et al. Ultrapotent human antibodies protect against SARS-CoV-2 challenge via multiple mechanisms. Science. 2020;370(6519):0950-7.

224. Köhler G, Milstein C. Continuous cultures of fused cells secreting antibody of predefined specificity. Nature. 1975;256(5517):495-7.

225. Kwakkenbos MJ, van Helden PM, Beaumont T, Spits H. Stable long-term cultures of self-renewing B cells and their applications. Immunol Rev. 2016;270(1):65-77.

226. Listek M, Hönow A, Gossen M, Hanack K. A novel selection strategy for antibody producing hybridoma cells based on a new transgenic fusion cell line. Sci Rep. 2020;10(1):1664.

227. Ejemel M, Li Q, Hou S, Schiller ZA, Tree JA, Wallace A, et al. A cross-reactive human IgA monoclonal antibody blocks SARS-CoV-2 spike-ACE2 interaction. Nat Commun. 2020;11(1):4198.

228. Antipova NV, Larionova TD, Siniavin AE, Nikiforova MA, Gushchin VA, Babichenko II, et al. Establishment of murine hybridoma cells producing antibodies against spike protein of SARS-CoV-2. Int J Mol Sci. 2020:21(23):9167.

229. Guo Y, Kawaguchi A, Takeshita M, Sekiya T, Hirohama M, et al. Potent mouse monoclonal antibodies that block SARS-CoV-2 infection. J Biol Chem. 2021;296:100346.

230. Chapman AP, Tang X, Lee JR, Chida A, Mercer K, Wharton RE, et al. Rapid development of neutralizing and diagnostic SARS-COV-2 mouse monoclonal antibodies. bioRxiv. 2020. https://doi.org/10.1101/2020.10. 13.338095 .

231. Menachery VD, Yount BL Jr, Debbink K, Agnihothram S, Gralinski LE, Plante JA, et al. A SARS-like cluster of circulating bat coronaviruses shows potential for human emergence. Nat Med. 2015;21(12):1508-13. [Erratum in: Nat Med 2016;22(4):446]

232. Ma Z, Li P, Ikram A, Pan Q. Does cross-neutralization of SARS-CoV-2 only relate to high pathogenic coronaviruses? Trends Immunol. 2020;41(10):851-3.

233. Hamers-Casterman C, Atarhouch T, Muyldermans S, Robinson G, Hamers C, Songa EB, et al. Naturally occurring antibodies devoid of light chains. Nature. 1993;363(6428):446-8.

234. Nuttall SD, Krishnan UV, Hattarki M, De Gori R, Irving RA, Hudson PJ. Isolation of the new antigen receptor from wobbegong sharks, and use as a scaffold for the display of protein loop libraries. Mol Immunol. 2001;38(4):313-26.

235. Lee CM, lorno N, Sierro F, Christ D. Selection of human antibody fragments by phage display. Nat Protoc. 2007;2(11):3001-8.

236. Chames P, Rothbauer U. Special Issue: Nanobody. Antibodies (Basel). 2020;9(1):6.

237. Morrison C. Nanobody approval gives domain antibodies a boost. Nat Rev Drug Discov. 2019;18(7):485-8

238. Wrapp D, De Vlieger D, Corbett KS, Torres GM, Wang N, Van Breedam W, et al. Structural basis for potent neutralization of Betacoronaviruses by single-domain camelid antibodies. Cell 2020;181(5):1004-1015.e15. [Erratum in: Cell 2020;181(6):1436-1441].

239. Boudewijns R, Thibaut HJ, Kaptein SJF, Li R, Vergote V, Seldeslachts L, Van Weyenbergh J, et al. STAT2 signaling restricts viral dissemination but drives severe pneumonia in SARS-CoV-2 infected hamsters. Nat Commun. 2020;11(1):5838

240. Esparza TJ, Martin NP, Anderson GP, Goldman ER, Brody DL. High affinity nanobodies block SARS-CoV-2 spike receptor binding domain interaction with human angiotensin converting enzyme. Sci Rep. 2020;10(1):22370.

241. Valenzuela Nieto G, Jara R, Watterson D, Modhiran N, Amarilla AA, Himelreichs J, et al. Potent neutralization of clinical isolates of SARSCoV-2 D614 and G614 variants by a monomeric, sub-nanomolar affinity nanobody. Sci Rep. 2021;11:3318.

242. Hanke L, Vidakovics Perez L, Sheward DJ, Das H, Schulte T, MolinerMorro A, et al. An al paca nanobody neutralizes SARS-CoV-2 by blocking receptor interaction. Nat Commun. 2020:11(1):4420.

243. Moliner-Morro A, Sheward D, Karl V, Perez Vidakovics L, Murrell B, McInerney GM, Hanke L. Picomolar SARS-CoV-2 neutralization using multi-arm PEG nanobody constructs. Biomolecules. 2020;10(12):1661.

244. Wagner TR, Kaiser PD, Gramlich M, Becker M, Traenkle B, Junker D, et al. NeutrobodyPlex-Nanobodies to monitor a SARS-CoV-2 neutralizing immune response. bioRxiv. 2020. https://doi.org/10.1101/2020.09.22. 308338.

245. Xiang Y, Nambulli S, Xiao Z, Liu H, Sang Z, Duprex WP, et al. Versatile and multivalent nanobodies efficiently neutralize SARS-CoV-2. Science. 2020:370(6523):1479-84.

246. Gai J, Ma L, Li G, Zhu M, Qiao P, Li X, et al. A potent neutralizing nanobody against SARS-CoV-2 with inhaled delivery potential. MedComm. 2021;2:101-13.

247. Zimmermann I, Egloff P, Hutter CAJ, Kuhn BT, Bräuer P, Newstead S, et al. Seeger, generation of synthetic nanobodies against delicate proteins. Nat Protoc. 2020;15(5):1707-41.

248. Walter JD, Hutter CAJ, Zimmermann I, Earp J, Egloff P, Sorgenfrei M, et al. Synthetic nanobodies targeting the SARS-CoV-2 receptor-binding domain. bioRxiv. 2020. https://doi.org/10.1101/2020.04.16.045419.

249. LiT, Cai H, Yao H, Zhou B, Zhang N, Gong Y, et al. A potent synthetic nanobody targets RBD and protects mice from SARS-CoV-2 infection. bioRxiv. 2020. doi.org/https://doi.org/10.21203/rs.3.rs-75540/v1. PPR:PPR218472.

250. Custódio TF, Das H, Sheward DJ, Hanke L, Pazicky S, Pieprzyk J, et al. Selection, biophysical and structural analysis of synthetic nanobodies that effectively neutralize SARS-CoV-2. Nat Commun. 2020;11(1):5588

251. Yao H, Cai H, Li T, Zhou B, Qin W, Lavillette D, Li D. A high-affinity RBDtargeting nanobody improves fusion partner's potency against SARSCoV-2. PLoS pathog. 2021;17(3):e1009328.

252. Schoof M, Faust B, Saunders RA, Sangwan S, Rezelj V, Hoppe N, et al. An ultra-high affinity synthetic nanobody blocks SARS-CoV-2 infection by locking Spike into an inactive conformation. bioRxiv. 2020. https://doi. org/10.1101/2020.08.08.238469.

253. Dong J, Huang B, Wang B, Titong A, Gallolu Kankanamalage S, Jia Z, et al. Development of humanized tri-specific nanobodies with potent neutralization for SARS-CoV-2. Sci Rep. 2020;10(1):17806.

254. Dong J, Huang B, Jia Z, Wang B, Gallolu Kankanamalage S, Titong A, Liu Y. Development of multi-specific humanized llama antibodies blocking SARS-CoV-2/ACE2 interaction with high affinity and avidity. Emerg Microbes Infect. 2020;9(1):1034-6.

255. Ye G, Gallant JP, Massey C, Shi K, Tai W, Zheng J, et al. The development of a novel nanobody therapeutic for SARS-CoV-2. bioRxiv. 2020. https:// doi.org/10.1101/2020.11.17.386532.

256. Wu Y, Li C, Xia S, Tian X, Kong Y, Wang Z, et al. Ying, Identification of human single-domain antibodies against SARS-CoV-2. Cell Host Microbe. 2020;27(6):891-898.e5.

257. Chi X, Liu X, Wang C, Zhang X, Li X, Hou J, et al. Humanized single domain antibodies neutralize SARS-CoV-2 by targeting the spike receptor binding domain. Nat Commun. 2020;11(1):4528.

258. Sun Z, Chen C, Li W, Martinez DR, Drelich A, Baek DS, et al. Potent neutralization of SARS-CoV-2 by human antibody heavy-chain variable domains isolated from a large library with a new stable scaffold. MAbs. 2020:12(1):1778435

259. Kaplon H. Reichert Antibodies to watch in 2021. MAbs. 2021;13:1.

260. Al-Rubeai M. Antibody expression and production. Cell engineering, vol. 7; 2007

261. Bandaranayake AD, Almo SC. Recent advances in mammalian protein production. FEBS Lett. 2014;588(2):253-60.

262. Walsh G. Biopharmaceutical benchmarks 2018. Nat Biotechnol. 2018;36(12):1136-45

263. Jayapal KP, Wlaschin KF, Hu WS, Yap MGS. Recombinant protein therapeutics from $\mathrm{CHO}$ cells -20 years and counting. Chem Eng Prog. 2007:103(10):40-7.

264. Wurm FM, Wurm MJ. Cloning of $\mathrm{CHO}$ cells, productivity and genetic stability—a discussion. Processes. 2017;5(2):20.

265. Sharker SM, Rahman MA. Review of the current methods of Chinese Hamster Ovary (CHO) cells cultivation for production of therapeutic protein. Curr Drug Discov Technol. 2020;17:1.

266. Kuo CC, Chiang AW, Shamie I, Samoudi M, Gutierrez JM, Lewis NE. The emerging role of systems biology for engineering protein production in CHO cells. Curr Opin Biotechnol. 2018;51:64-9.

267. Sarsaiya S, Shi J, Che J. Bioengineering tools for the production of pharmaceuticals: current perspective and future outlook. Bioengeneered. 2019;10:469-92. 
268. Pérez-Rodriguez S, Ramírez-Lira MJ, Trujillo-Roldán MA, Valdez-Cruz NA. Nutrient supplementation strategy improves cell concentration and longevity, monoclonal antibody production and lactate metabolism of Chinese hamster ovary cells. Bioengineered. 2020;11(1):463-71.

269. Golabgir A, Gutierrez JM, Hefzi H, Li S, Palsson BO, Herwig C, Lewis NE. Quantitative feature extraction from the Chinese hamster ovary bioprocess bibliome using a novel meta-analysis workflow. Biotechnol Adv. 2016;34(5):621-33.

270. Kelley B. Industrialization of mAb production technology: the bioprocessing industry at a crossroads. MAbs. 2009;1:443-52.

271. Welch JT, Arden NS. Considering "clonality": a regulatory perspective on the importance of the clonal derivation of mammalian cell banks in biopharmaceutical development. Biologicals. 2019;62:16-21.

272. Radhakrishnan D, Wells EA, Robinson AS. Strategies to enhance productivity and modify product quality in therapeutic proteins. Curr Opin Chem Eng. 2018;22:81-8.

273. Klutz S, Holtmann L, Lobedann M, Schembecker G. Cost evaluation of antibody production processes in different operation modes. Chem Eng Sci. 2016;141:63-74.

274. Wu Y, Jiang S, Ying T. Single-domain antibodies as therapeutics against human viral diseases. Front Immunol. 2017;8:1802.

275. Steeland S, Vandenbroucke RE, Libert C. Nanobodies as therapeutics: big opportunities for small antibodies. Drug Discov Today. 2016:21(7):1076-113.

276. Mead EJ, Chiverton LM, Smales CM, von der Haar T. Identification of the limitations on recombinant gene expression in $\mathrm{CHO}$ cell lines with varying luciferase production rates. Biotechnol Bioeng. 2009;102(6):1593-602.

277. Wu NC, Yuan M, Liu H, Lee CD, Zhu X, Bangaru S, et al. An alternative binding mode of IGHV3-53 antibodies to the SARS-CoV-2 receptor binding domain. Cell Rep. 2020;33(3):108274.

278. Johari YB, Jaffé SRP, Scarrott JM, Johnson AO, Mozzanino T, Pohle TH, et al. Production of trimeric SARS-CoV-2 spike protein by $\mathrm{CHO}$ cells for serological COVID-19 testing. Biotechnol Bioeng. 2020. https://doi.org/ 10.1002/bit.27615.

279. DeFrancesco L. COVID-19 antibodies on trial. Nat Biotechnol. 2020;38(11):1242-52.

280. Marovich M, Mascola JR, Cohen MS. Monoclonal antibodies for prevention and treatment of COVID-19. JAMA. 2020;324(2):131-2.

281. Fischer $\mathrm{S}$, Handrick $\mathrm{R}$, Otte $\mathrm{K}$. The art of $\mathrm{CHO}$ cell engineering: a comprehensive retrospect and future perspectives. Biotechnol Adv. 2015:33:1878-96

282. Maruthamuthu MK, Rudge SR, Ardekani AM, Ladisch MR, Verma MS. Process analytical technologies and data analytics for the manufacture of monoclonal antibodies. Trends Biotechnol. 2020;38(10):1169-86.

283. He C, Ye P, Wang H, Liu X, Li F. A systematic mass-transfer modeling approach for mammalian cell culture bioreactor scale-up. Biochem Eng J. 2019;141:173-81.
284. Karst DJ, Steinebach F, Soos M, Morbidelli M. Process performance and product quality in an integrated continuous antibody production process. Biotechnol Bioeng. 2017;114:298-307.

285. Challener CA. Process Chromatography: continuous Optimization, Improved resin chemistries and customized separation solutions are enabling more efficient separations. BioPharm Int. 2017;30(8):14-7.

286. Bando-Campos G, Juárez-López D, Román-González SA, Castillo-Roda Al, Olvera C, López-Vidal Y, et al. Recombinant O-mannosylated protein production (PstS-1) from Mycobacterium tuberculosis in Pichia pastoris (Komagataella phaffii) as a tool to study tuberculosis infection. Microb Cell Fact. 2019;18(1):1-19.

287. Alt N, Zhang TY, Motchnik P, Taticek R, Quarmby V, Schlothauer T, et al. Determination of critical quality attributes for monoclonal antibodies using quality by design principles. Biologicals. 2016;44(5):291-305.

288. Bellino S, Punzo O, Rota MC, Del Manso M, Urdiales AM, Andrianou X, COVIS-19 WORKING GROUP, et al. COVID-19, disease severity risk factors for pediatric patients in Italy. Pediatrics. 2020;146(4):e2020009399.

289. Nogrady B. How kids' immune systems can evade COVID. Nature. 2020;588(7838):382.

290. Cathcart AL, Havenar-Daughton C, Lempp FA, Ma D, Schmid M Agostini ML, et al. The dual function monoclonal antibodies VIR-7831 and VIR-7832 demonstrate potent in vitro and in vivo activity against SARS-CoV-2. bioRxiv. 2021. https://doi.org/10.1101/2021.03.09.434607.

291. Singh S, Kumar NK, Dwiwedi P, Charan J, Kaur R, Sidhu P, Chugh VK. Monoclonal antibodies: a review. Curr Clin Pharmacol. 2018;13(2):85-99.

292. Banach BB, Cerutti G, Fahad AS, Shen CH, de Souza MO, Katsamba PS, et al. Paired heavy and light chain signatures contribute to potent SARS-CoV-2 neutralization in public antibody responses. bioRxiv. 2021. https://doi.org/10.1101/2020.12.31.424987.

293. Miersch S, Li Z, Saberianfar R, Ustav M, Case JB, Blazer L, et al. Tetravalent SARS-CoV-2 neutralizing antibodies show enhanced potency and resistance to escape mutations. bioRxiv. 2020. https://doi.org/10.1101/ 2020.10.31.362848.

294. Hurlburt NK, Seydoux E, Wan YH, Edara WV, Stuart AB, Feng J, et al. Structural basis for potent neutralization of SARS-CoV-2 and role of antibody affinity maturation. Nat Commun. 2020;11(1):1-7.

295. Li D, Edwards RJ, Manne K, Martinez DR, Schäfer A, Alam SM, et al. The functions of SARS-CoV-2 neutralizing and infection-enhancing antibodies in vitro and in mice and nonhuman primates. bioRxiv. 2021. https:// doi.org/10.1101/2020.12.31.424729.

\section{Publisher's Note}

Springer Nature remains neutral with regard to jurisdictional claims in published maps and institutional affiliations.

Ready to submit your research? Choose BMC and benefit from:

- fast, convenient online submission

- thorough peer review by experienced researchers in your field

- rapid publication on acceptance

- support for research data, including large and complex data types

- gold Open Access which fosters wider collaboration and increased citations

- maximum visibility for your research: over $100 \mathrm{M}$ website views per year

At BMC, research is always in progress.

Learn more biomedcentral.com/submissions 